FACULDADE DE TECNOLOGIA E CIÊNCIAS SOCIAIS APLICADAS FATECS

\author{
PROGRAMA DE INICIAÇÃO CIENTÍFICA \\ MARIANA DE MELLO BUENO \\ RAÍSSA LEAL LIMA
}

\title{
A ARQUITETURA BRUTALISTA DE JOSÉ GALBINSKI EM BRASÍLIA \\ O Restaurante Universitário e o CPD da UnB: \\ Uma Análise Comparativa
}




\section{Unल $\mathbf{U}$ \\ Centro Unıversitárıo de Brasílıa}

\section{CENTRO UNIVERSITÁRIO DE BRASÍLIA - UniCEUB FATECS

\author{
MARIANA DE MELLO BUENO \\ RAÍSSA LEAL LIMA
}

FACULDADE DE TECNOLOGIA E CIÊNCIAS SOCIAIS APLICADAS -

\section{A ARQUITETURA BRUTALISTA DE JOSÉ GALBINSKI EM BRASÍLIA \\ O Restaurante Universitário e o CPD da UnB: \\ Uma Análise Comparativa}

Relatório final de pesquisa de Iniciação Científica apresentado à Assessoria de Pós-Graduação e Pesquisa pela Faculdade de Tecnologia e Ciências Sociais Aplicadas - FATECS

Orientação: Emília Stenzel 


\title{
Resumo
}

\section{A ARQUITETURA BRUTALISTA DE JOSÉ GALBINSKI EM BRASÍLIA O Restaurante Universitário e o CPD da UnB: Uma Análise Comparativa}

Mariana de Mello Bueno - UniCEUB, PIC Institucional, aluna bolsista marianademelloarquitetura@gmail.com

Raíssa Leal Lima - UniCEUB, PIC Institucional, aluna voluntária raissaleal.arq@gmail.com

\author{
Emilia Stenzel - UniCEUB, professora orientadora \\ emilia.stenzel@uniceub.br
}

A pesquisa apresenta uma análise comparativa dos projetos do Restaurante Universitário e do Centro de Processamento de Dados da Universidade de Brasília, ambos realizados pelo arquiteto José Galbinski. O objetivo do trabalho foi evidenciar características espaciais e morfológicas dos projetos em tela, no sentido de precisar as características que determinaram sua condição de paradigmas da vertente brasiliense do Brutalismo. Inicialmente a pesquisa definiu um leque preliminar de variáveis de projeto a serem analisadas, tomando como campo de referência o daquelas que marcaram o contexto das práticas e do ideário da vertente brutalista da arquitetura no plano internacional e, de forma mais especifica, no plano nacional, que constituiu expressiva vertente e teve na obra construída e teórica de João Vilanova Artigas, de quem José Galbinski foi discípulo, sua expressão maior. Em seguida, recorrendo a modelos tridimensionais dos referidos projetos, efetuou-se a análise diagramática das variáveis pré-definidas e de outras que foram sendo sugeridas pelos resultados obtidos com os diagramas elaborados. Os aspectos analisados - de natureza programática, locacional, construtiva, geométrica e ambiental - permitiram compor um quadro dos elementos característicos das articulações espaciais e da morfologia dos referidos projetos, características que contribuíram para delinear a variante brasiliense do Brutalismo. A pesquisa evidenciou que tais aspectos alteravam em larga medida, quando não invertiam, as soluções encontradas nas tipologias do modernismo então vigente na capital, de matriz carioca. Ao ser efetuada de forma comparativa, a análise de tais variáveis em um e outro projeto permitiu que 
se evidenciassem também estratégias projetuais empregadas por José Galbinski naquela fase de sua atuação profissional. Com isso, a pesquisa contribuiu também para precisar aspectos da contribuição do arquiteto para o surgimento da vertente brasiliense do Brutalismo, e para o surgimento de novos rumos na arquitetura da capital a partir da década de 70 .

Palavras-chave: Arquitetura. Brutalismo. Brasília. José Galbinski. 


\section{Lista de llustrações}

Figura 1 - Unidade Habitacional de Marselha - Marselha/FR. ................................

Figura 2 - Fachada MAM - Rio de Janeiro/RJ..............................................11

Figura 3 - Fachada Centro Evangélico - Porto Alegre/RS ...................................13

Figura 4 - Interior Centro Evangélico - Porto Alegre/RS ......................................13

Figura 5 - Fachada Clube do Professor Gaúcho - Porto Alegre/RS .......................14

Figura 6 - Residência Barão de Uba - Porto Alegre/RS. .....................................15

Figura 7 - Residência Barão de Uba - Porto Alegre/ RS ......................................15

Figura 8 - Estádio do Morumbi - São Paulo/SP ................................................17

Figura 9 - FAU - USP - São Paulo/SP ....................................................18

Figura 10 - Fachada Biblioteca Central - UNB - Brasília/DF .............................21

Figura 11 - Interior Biblioteca Central - UNB - Brasília/DF ................................22

Figura 12 - .Fachada Casa Thomas Jefferson no Lago Sul - Brasília/DF................23

Figura 13 - Residência Galbinski - Brasília/DF ...............................................23

Figura 14 - Maquete Sede do Banco Interamericano de Desenvolvimento (BID) .....24

Figura 15 - Foto do croqui original do arquiteto indicando a localização do CPD......25

Figura 16 - Maquete eletrônica do CPD .....................................................26

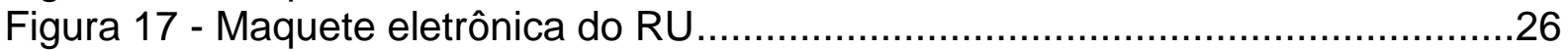

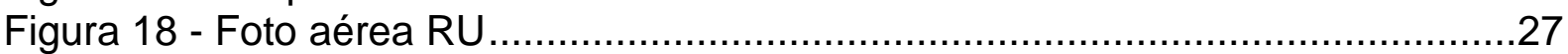

Figura 19 - Campus Darcy Ribeiro - década 70/80 ............................... 27

Figura 20 - Foto com indicação da localização do RU (vermelho) e CPD (amarelo).28

Figura 21 - Diagrama da vista superior do CPD …….........................................30

Figura 22 - Diagrama pavimentos - Elevação A do CPD.......................................31

Figura 23 - Diagrama pavimentos - Elevação B do CPD.......................................32

Figura 24 - Diagrama pavimentos - Elevação $C$ do CPD ........................................33

Figura 25 - Diagrama pavimentos - Elevação D do CPD ………….....................34

Figura 26 - Diagramas das elevações A, B, C e D do CPD .....................................35

Figura 27 - Diagrama da vista superior do RU ................................................36

Figura 28 - Diagrama pavimentos - Elevação A do RU ..........................................37

Figura 29 - Diagrama pavimentos - Elevação B do RU .........................................38

Figura 30 - Diagrama pavimentos - Elevação $C$ do RU..........................................39

Figura 31 - Diagrama pavimentos - Elevação D do RU........................................40

Figura 32 - Diagramas das elevações A, B, C e D do RU ....................................41

Figura 33 - Diagrama relação lajes e cobertura - vista superior do CPD ...................42

Figura 34 - Diagrama relações lajes e cobertura - vista superior do RU ...................44

Figura 35 - Diagrama da relação espelho d'água - CPD .......................................46

Figura 36 - Diagrama da relação espelho d'água - RU ................Erro! Indicador não definido.48

Figura 37 - Diagrama de circulação vertical - CPD...........................................48

Figura 38 - Diagrama de circulação vertical - RU .................................................49

Figura 39 - Diagama de espaços imersivos - CPD vista $1 \ldots \ldots \ldots \ldots \ldots \ldots \ldots \ldots \ldots \ldots \ldots \ldots . . .50$

Figura 40 - Diagrama de espaços imersivos - CPD vista 2 ..................................50

Figura 41 - Diagrama de espaços imersivos - RU vista 1 ...................................52

Figura 42 - Diagrama de espaços imersivos - RU vista 2 ...................................52

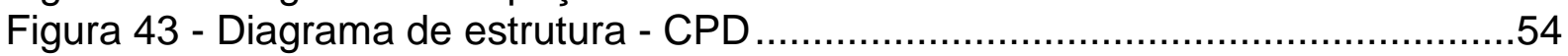

Figura 44 - Diagrama de estrutura - RU ......................................................55

Figura 45 - Diagrama de abertura zenital - Vista superior CPD ............................56

Figura 46 - Diagrama de aberturas zenitais - Vista superior RU ..........................57

Figura 47 - Diagrama de fechamento em vidro - CPD vista 1 ...............................58 
Figura 48 - Diagrama de fechamento em vidro - CPD vista 2 ................................58

Figura 49 - Diagrama de fechamento em vidro - RU vista 1 ..................................59

Figura 50 - Diagrama de fechamento em vidro - RU vista 2 ................................59

Figura 51 - Diagrama de elementos em brise - CPD vista 1 .............................60

Figura 52 - Diagrama de fechamento em brise - CPD vista 2 ...............................60

Figura 53 - Diagrama de fechamento em brise - RU ........................................61

Figura 54 - Diagrama de topografia CPD - vista superior ....................................62

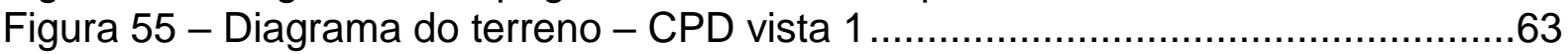

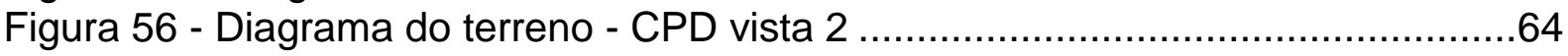

Figura 57 - Diagrama de topografia - RU - vista superior ...................................63

Figura 58 - Diagrama do terreno - RU vista 2 .................................................64

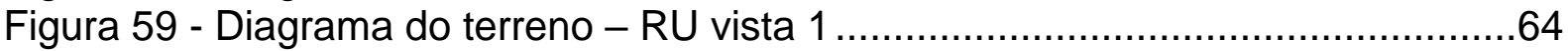




\section{Lista de Siglas}

CPD Centro de Processamento de Dados

NDP Núcleo de Documentação e Pesquisa da Arquitetura e do Urbanismo de Brasília - CAU/Uniceub

RU Restaurante Universitário

UNB Universidade de Brasília

USP Universidade de São Paulo 


\section{Sumário}

1. Introdução

1.1. Estudo do Contexto de Emergência dos Projetos do RU e do CPD: $O$ Brutalismo Arquitetônico dos anos 70

1.1.1. Panorama Internacional e Nacional do Desenvolvimento do Brutalismo

1.1.2. Artigas na USP e o surgimento da vertente paulista

1.1.3. José Galbinski na UNB e o surgimento de uma vertente brasiliense20

2. Desenvolvimento 24

2.1. Definição das Variáveis Morfológicas e Espaciais .................................24

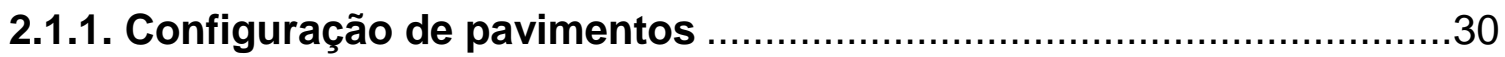

2.1.2. Relação Laje e Cobertura ............................................................

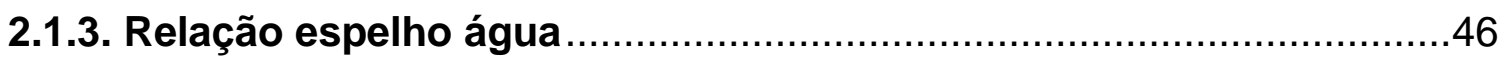

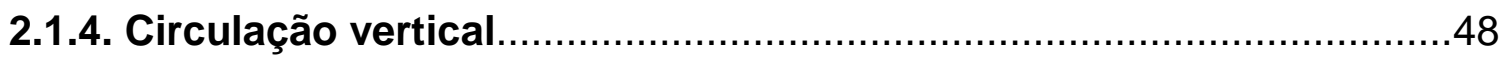

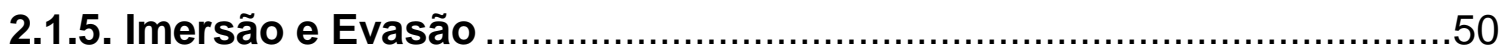

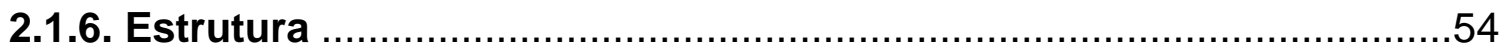

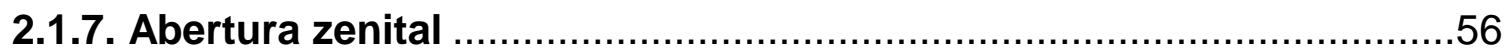

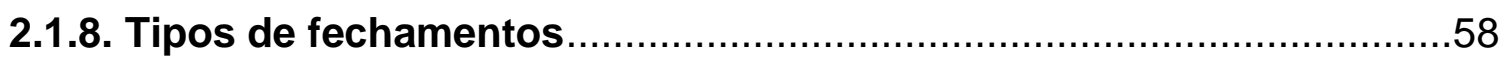

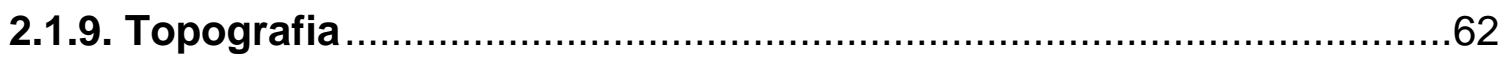

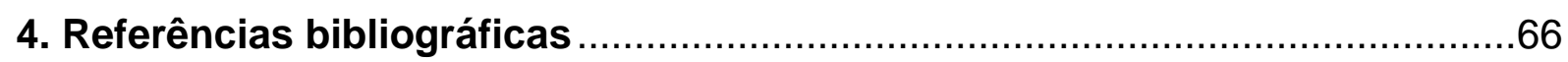




\section{Introdução}

\subsection{Estudo do Contexto de Emergência dos Projetos do RU e do} CPD: O Brutalismo Arquitetônico dos anos 70

\subsubsection{Panorama Internacional e Nacional do Desenvolvimento do Brutalismo}

As obras de José Galbinski que constituiem o objeto dessa pesquisa, pertencem à fase de produção do arquiteto fortemente marcadas pelo Brutalismo.

O Brutalismo identifica primeiramente a opção formal pelo uso do concreto aparente („béton brut") que caracterizou a obra de Le Corbusier a partir da unidade habitacional de Marselha (1947-1952). Com o uso do concreto bruto e a opção pela pureza quanto à estrutura e aos materiais, o projeto da "Unité" era visto por seu autor como "capaz de devolver a dignidade da arquitetura à mais simples moradia individual", o que remetia a um ideal de valores socialistas. ${ }^{1}$

No entanto, a designação "brutalismo" surge somente em 1954 na Inglaterra e, de acordo com Rayner Banham, no início o objetivo era qualificar as aspirações de um grupo de jovens arquitetos, que começavam a desenvolver o assim chamado Brutalismo Inglês.

Mas devemos fazer distinção entre o Brutalismo de Le Corbusier, e o Brutalismo Inglês, que como os de vários outros países, dentre estes o Brasil, foram inspirados na obra de Le Corbusier.

\footnotetext{
${ }^{1}$ FRAMPTON, Kenneth. História critica da arquitetura moderna. São Paulo, Martins Fontes, 2000.
} 


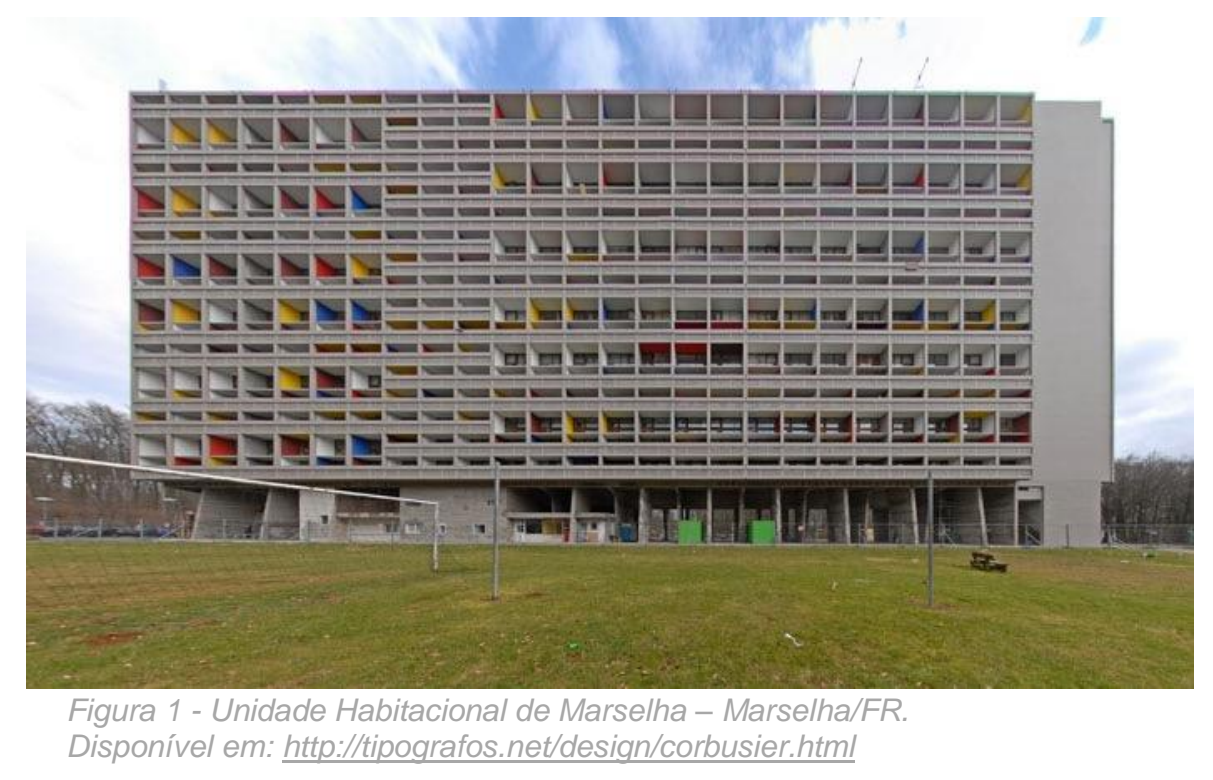

No Brasil, o Brutalismo foi antecedido pela arquitetura moderna, que teve a Semana de Arte Moderna de 22 como propulsora. No pós-guerra (1940-1970), um período de processo político complexo acontecia o fim do nazismo e da ditadura de Vargas. O país estava atrasado e precisava de um impulso. Os arquitetos foram agentes dessa transformação. ${ }^{2}$

Com o pós-guerra, Vilanova Artigas foi em busca de uma vertente arquitetônica que respondesse às novas condições do pós-guerra, por possibilidades técnicas com potencial „revolucionário“, que pudessem levar países não-industrializados até o progresso. É neste contexto que surge a versão paulista do Brutalismo, marcada pelas posições de esquerda de Artigas, que em seus artigos atacava posições "burguesas" e seduzia arquitetos que consolidaram essa tendência estética no Brasil.

No plano formal Artigas teve muito da influência de Le Corbusier, mas no plano da ação, visou objetivos discrepantes. Percebendo que não poderia implantar sua idealizada arquitetura socialista, dedicou-se a tratar seus projetos com espírito

2 ARTIGAS, Vilanova. Caminhos da Arquitetura: Vilanova Artigas. São Paulo, Cosac \& Naify, 1999, p. 139. 
comunitário, onde convergia seu amor pelo material bruto, preocupações por espaços internos unificados e a organização racional com fins psicológicos. ${ }^{3}$

O Brutalismo desenvolveu-se também no Rio de Janeiro e no Rio Grande do Sul. Grosso modo, o que difere a escola paulista da escola carioca, é que no caso paulista o concreto desenformado era mantido usualmente bruto, sem tratamentos ou pinturas, enquanto que nos exemplos cariocas buscava-se uma plasticidade lírica que se distanciava do caráter pouco cuidado e rústico da primeira, os arquitetos cariocas aderiam parcialmente a aplicação do concreto como material definitivo, após a forma despojada que Reidy inaugurou no MAM. ${ }^{4}$

${ }^{3}$ BRUAND, Yves. Arquitetura contemporânea no Brasil. São Paulo, Editora Perspectiva,2002, p.295303.

${ }^{4}$ LUCCAS, Luis Henrique Haas, Concreto aparente e valorização da estrutura: A influência estética do brutalismo em Porto Alegre nos anos 60/70, X Seminário Docomomo Brasil, PUC-PR, Curitiba, 2013, p. 10 e 11. 


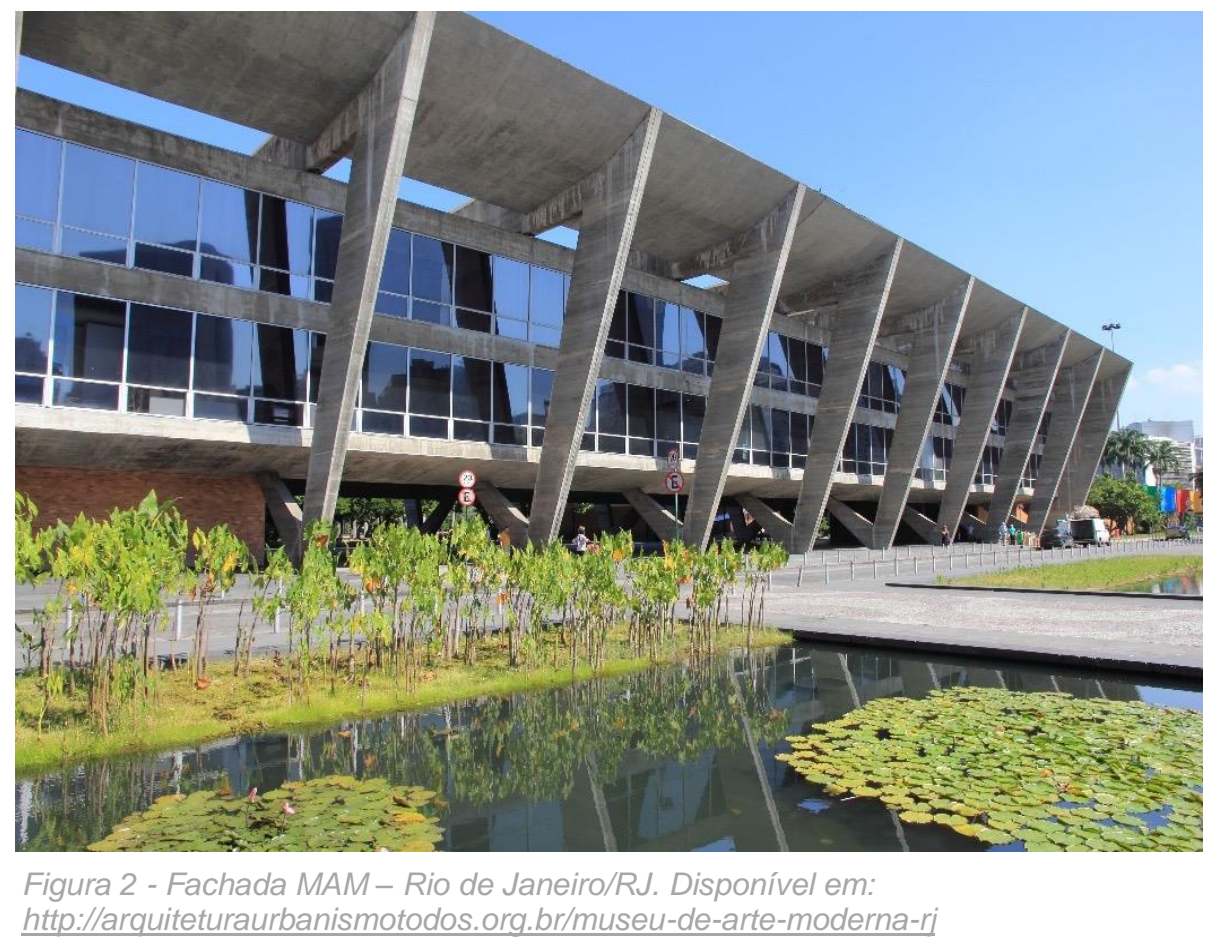

Apesar de naquele então, São Paulo ser o novo centro da arquitetura brasileira, também por uma causa político-econômica, é perceptível que o brutalismo de Porto Alegre não teve apenas a Escola Paulista como referência. Segundo Luis Henrique Hass Luccas, são claramente percebidas fontes como Le Corbusier e Mies.

[...] Paralelamente à preferência pelos materiais industrializados, estandardizações, soluções construtivas e arranjos compositivos próprios da produção sintética simplificada como internacionalizada, a arquitetura portoalegrense registrou o surgimento e avanço gradual da exploração formal do concreto aparente e da estrutura, como conseqüência do brutalismo igualmente surgido no pós-guerra.

Em Porto Alegre, a primeira obra com concreto à mostra foi o Centro Evangélico, resultado de um concurso realizado em 1959. O material começou a ser utilizado gradualmente em pilares, vigas e outros elementos, associando de modo híbrido o brutalismo às outras vertentes vigentes. O Centro Evangélico teve autoria de Carlos Fayet e Suzy Brücker. O programa de necessidades incluía templo, estacionamentos, habitação para pastores, salas para cursos e festas, jardim de 
infância e administração. O pátio assumiu a função de adro de ingresso e claustro, recriando uma atmosfera conventual. "O edifício compôs um marco limite entre períodos, aplicando simultaneamente soluções corbusianas consagradas na fase inicial, influências do Le Corbusier maduro e a neutralidade identificada com Mies." ${ }^{5}$

5 Ibidem, 2013, p. 3 e 4. 


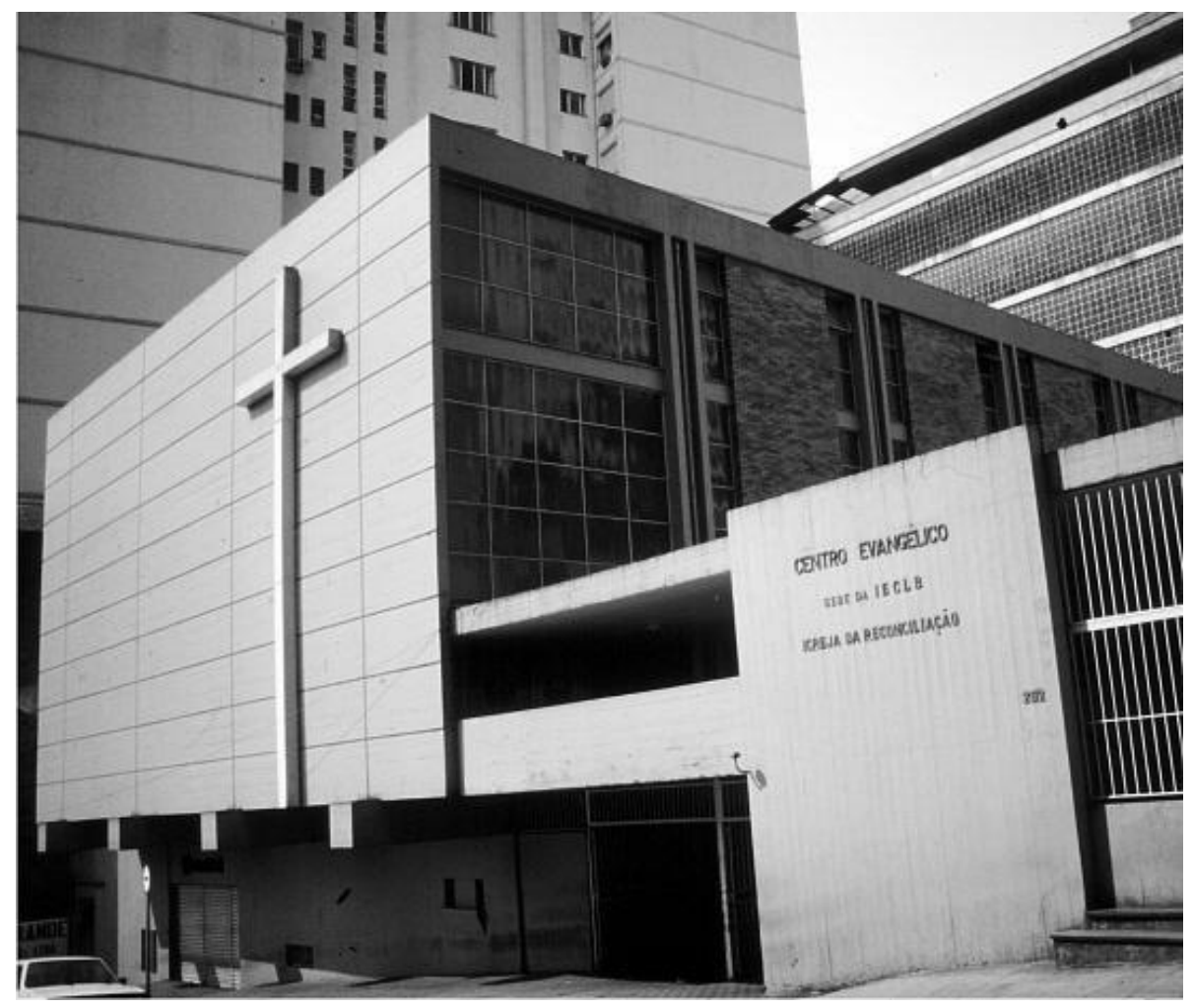

Figura 3 - Fachada Centro Evangélico - Porto Alegre/RS. Disponível em:

http://images.adsttc.com/media/images/5788/2019/e58e/ceaa/3300/0017/slideshow/8 FAM.jpg?1468538903

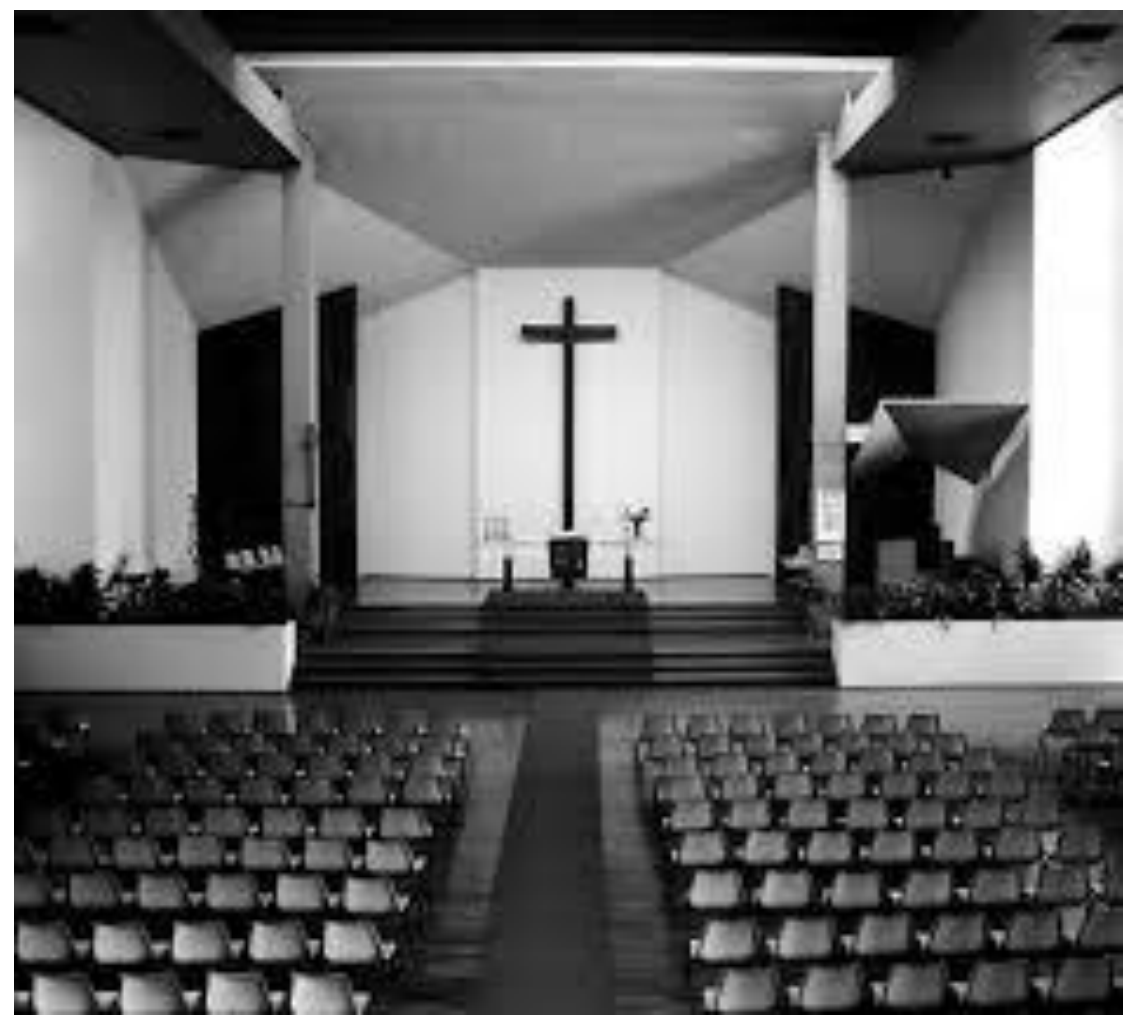

Figura 4 - Interior Centro Evangélico - Porto Alegre/RS. Disponível em: https://encrypted-tbn3.gstatic.com/images?q=tbn:ANd9GcRcHV10LmyHRB8pa ADV7yGVbjvyOSEhOIABihaBbMnPvF5XWf 


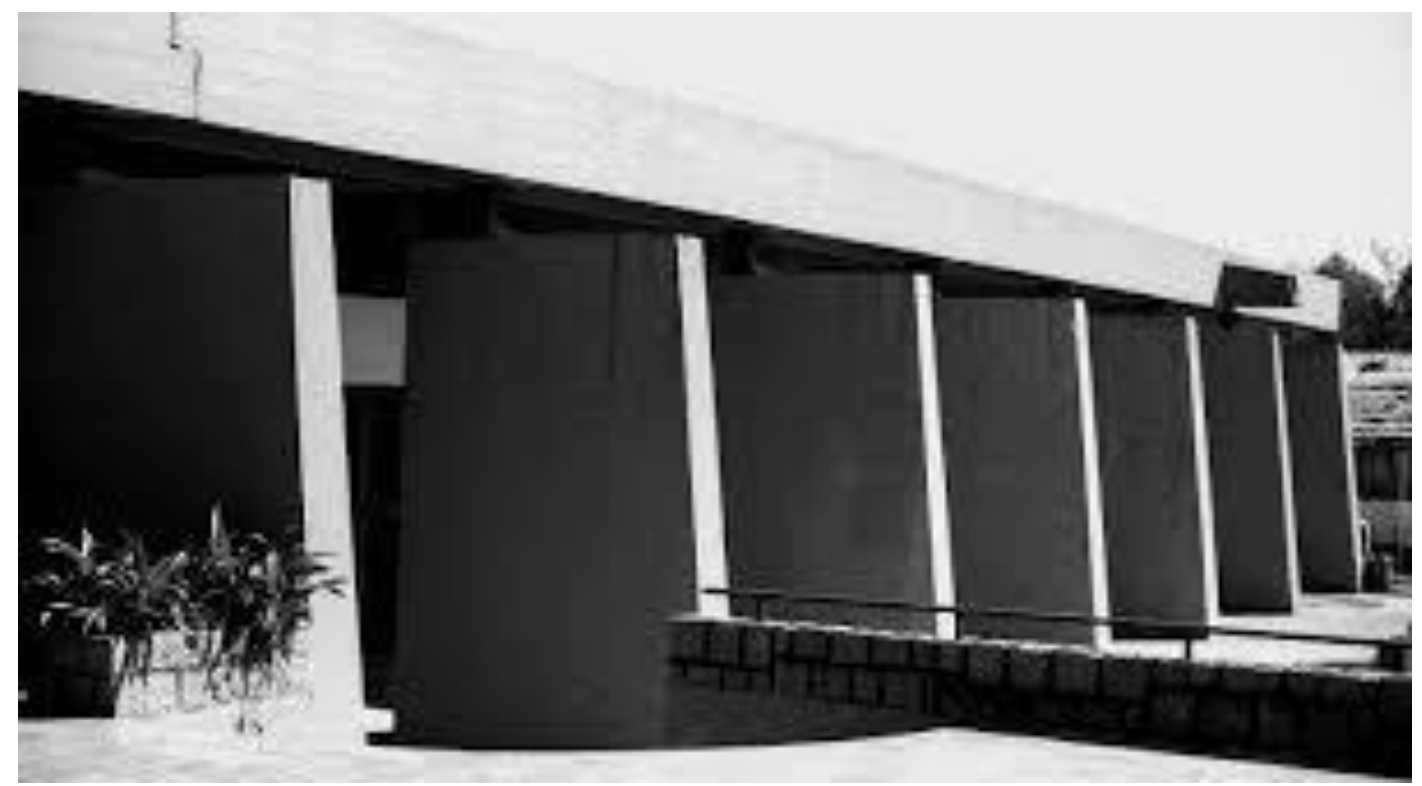

Figura 5 - Fachada Clube do Professor Gaúcho - Porto Alegre/RS. Disponível em: http://www.lume.ufrgs.br/bitstream/handle/10183/140231/000985673.pdf?sequence=1

Outro projeto do período a destacar foi o Clube do Professor Gaúcho (1966), de João José Vallandro e Moacyr Marques. Em sua proposta original apresentava vãos amplo e concreto aparente aplicado de forma global, como a Escola Paulista; soluções que não foram executadas de modo integral, prejudicando sensivelmente o resultado final. A sequência de pilares definiu a composição de modo vertical, distribuindo a composição sobre o terreno de modo contrastante com o referencial paulista. As formas "megalíticas" foram unificadas pela grande cobertura horizontal análoga às superestruturas dos projetos de Artigas e Cascaldi. Pouco utilizadas no brutalismo paulista e até mesmo ausentes na obra de Artigas e Paulo Mendes, as gárgulas adotadas remetem à Le Corbusier e reforçam a escala colossal da composição. 


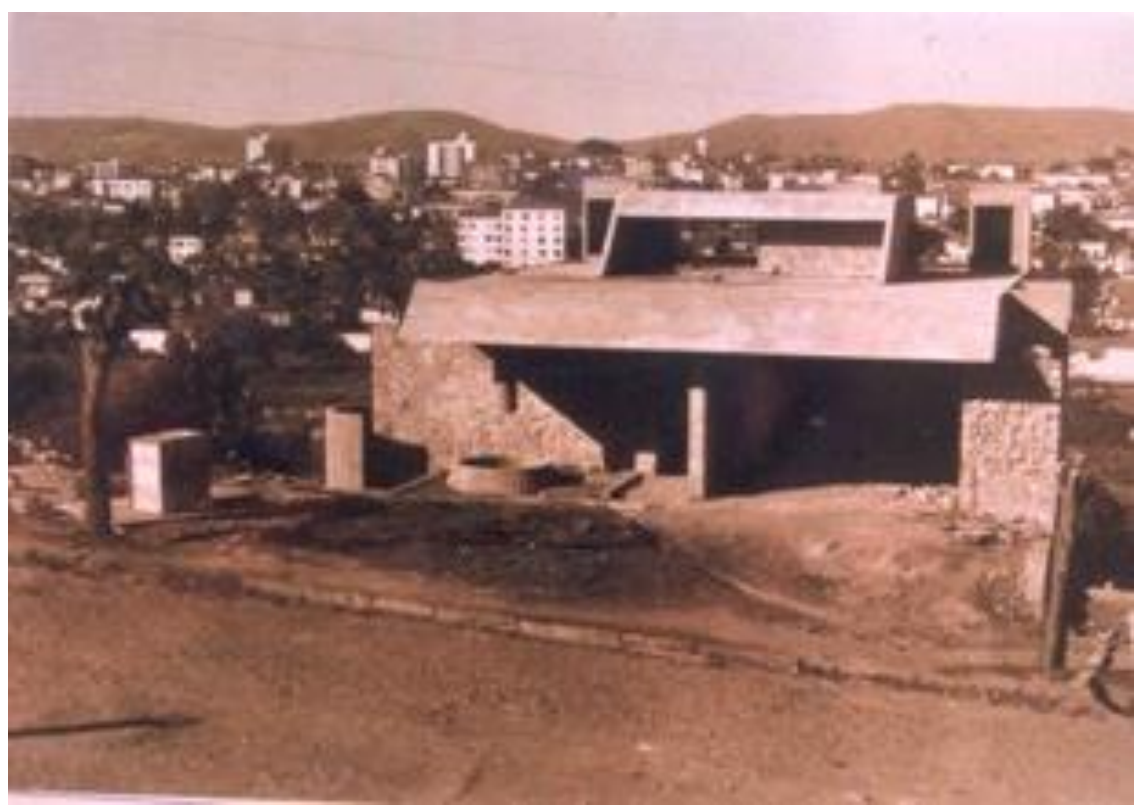

Figura 6 - Residência Barão de Uba - Porto Alegre/ RS. Arquivo NDP - UniCEUB

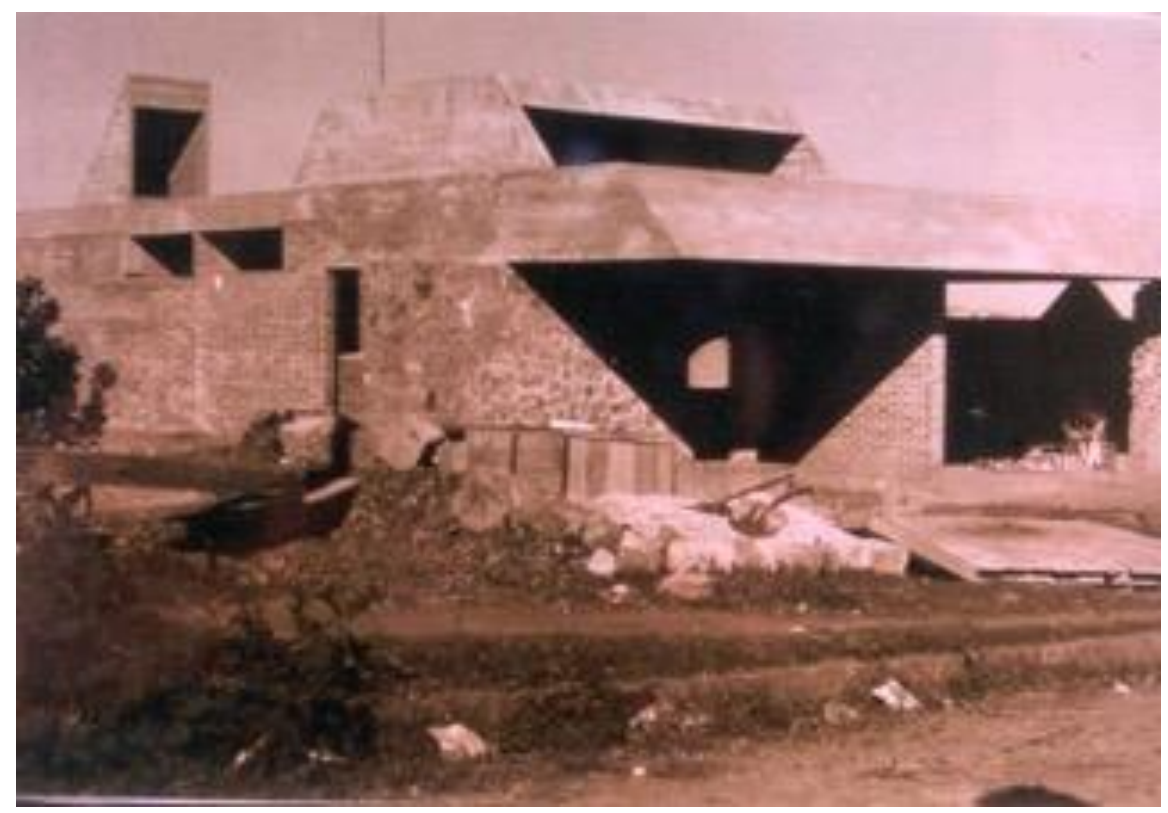

Figura 7 - Residência Barão de Uba - Porto Alegre/RS. Arquivo NPD - UniCEUB 
Todo o conjunto tentava recriar uma expressão brutalista de caráter mais autoral. ${ }^{6}$

É nesse contexto que José Galbinski inicia sua produção arquitetônica de cunho brutalista. Nesta primeira fase se destacam projetos como o da Residencia Barão de Ubá, na qual, pela primeira vez no Estado, o concreto aparente é usado em um programa residencial.

Após o governo Kubitschek a economia começou a sentir o déficit público e a inflação crescente, Jango assumia o poder e, acusado de promover uma república sindicalista e ameaçar a ordem, seria deposto através do golpe militar de 1964. Com este pretexto foi instituído o golpe militar estabilizando assim a economia e conduzindo o país ao "milagre econômico". Com o crescimento do PIB do país, a saída de Costa e Silva e a entrada de Médici no poder, a ditadura foi configurada rigorosamente e um período de grande progresso material foi instaurado. $O$ momento foi de muitas e grandes obras, o que como consequência consolidou a vertente brutalista, também pelo seu discurso de esquerda, em que a justificativa das obras por preocupações sociais seria a causa,

[...] Desse modo, os grandes vãos perseguidos no período passaram a significar espaços democráticos; a permeabilidade daquela arquitetura - ou alveolaridade - foi justificada como expansão do público sobre o privado; a eliminação de divisões expressava o triunfo do coletivo sobre individual; e a rusticidade e síntese usuais representavam sobriedade, negação ao supérfluo. ${ }^{7}$

Com exceção da REFAP, a arquitetura de Porto Alegre nos anos sessenta se concentrava na iniciativa privada. Somente no final da década seriam destinados alguns empreendimentos de maior porte à cidade, como a abertura da Avenida Primeira Perimetral, os viadutos Loureiro da Silva, Tiradentes, Obirici, Imperatriz Leopoldina e o túnel e elevadas da Conceição; obras que incorporaram o concreto à paisagem urbana.

Nos anos setenta, instituições financeiras paulistas como o Banespa adotaram aquela arquitetura representativa local, cujas filiais atingiriam cidades como Porto Alegre. As formas próprias do discurso contestatório do brutalismo paulista passavam a integrar o marketing das instituições econômicas de modo acrítico. A situação era semelhante

\footnotetext{
6 lbidem, 2013, p. 6 e 7.
}

7 Ibidem, 2013, p. 10. 
na capital gaúcha, onde profissionais locais projetavam algumas agências da Caixa Econômica Federal e do Banco do Brasil plausivelmente influenciados por aquela Escola, conjuntamente com outras referências e desenvolvimentos autorais. ${ }^{8}$

\subsubsection{Artigas na USP e o surgimento da vertente paulista}

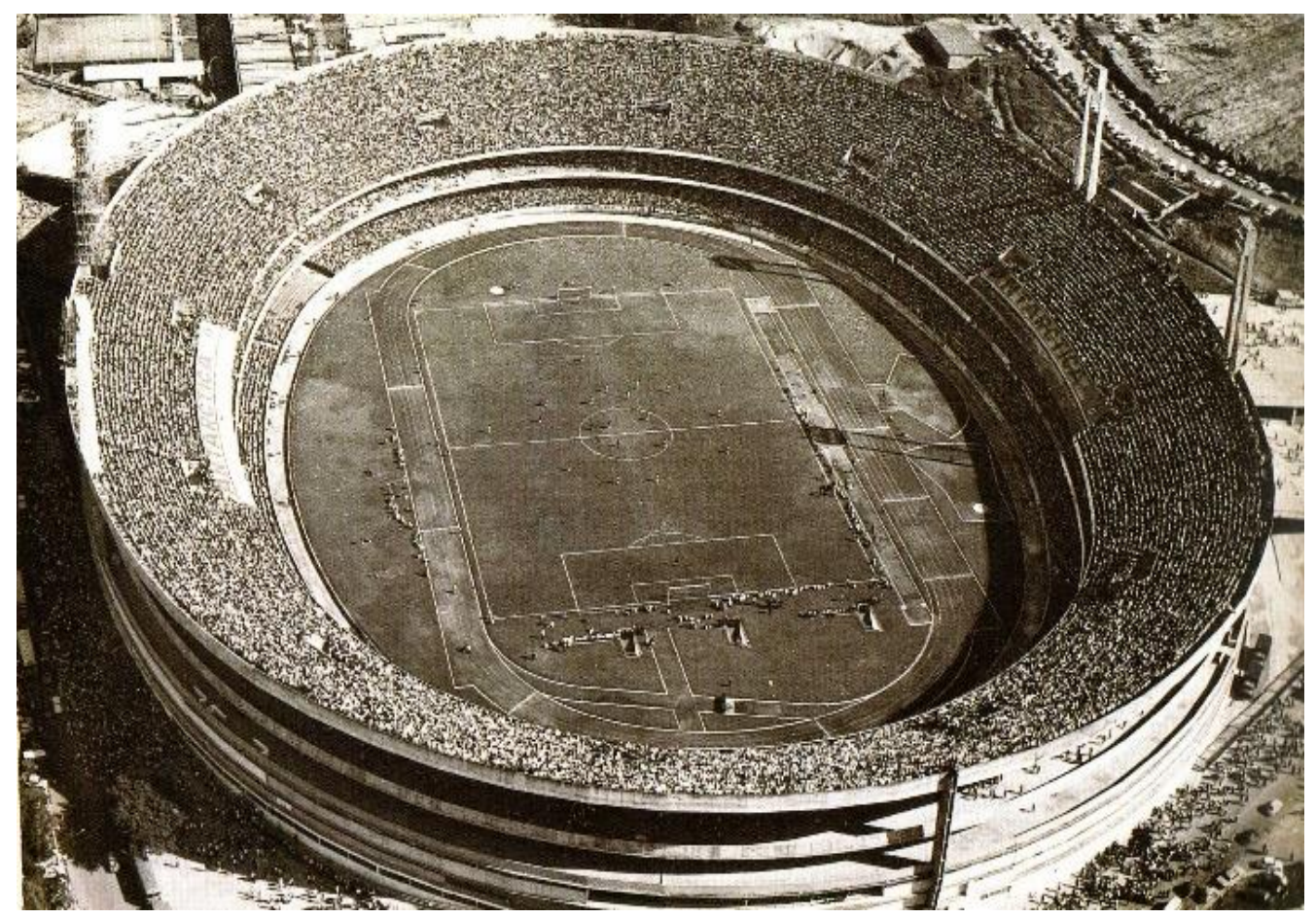

Figura 8 - Estádio do Morumbi - São Paulo/SP. Disponível em. http://www.tricolorontherock.com.br/a-construcao-do-morumbil

Com prerrogativas arquitetônicas como, escolha por materiais modernos, estruturas independentes em concreto armado, volumes geométricos claros, jogos de rampas e níveis desencontrados, transparência, continuidade exterior-interior, variações formais com repertórios racionalistas, imposição de um novo modo de viver e um ideal estético, o arquiteto iniciou a vertente brutalista paulista. Lançando o concreto bruto, no estado como sai da forma, em seu projeto para o estádio do Morumbi (1953), crava verdadeiramente um período inicial de transição em sua história. ${ }^{9}$

\footnotetext{
8 Ibidem, 2013, p.13 e 14

9 Ibidem, 2002, p.298.
} 
Após alguns anos foi oferecida a Artigas a possibilidade de afirmar seu novo estilo, projetando a futura Faculdade de Arquitetura e Urbanismo da Universidade de São Paulo. Então professor da faculdade, foi the oferecido um terreno plano e toda liberdade de ação. A obra, a qual o projeto data de 1961, foi construída entre 1966 e 1969, constituída por

[...] um vasto paralelepípedo retangular de faces laterais cegas, todo em concreto bruto, montado em pilares do mesmo material, dos quais só os que ficam no contorno são claramente visíveis - e tão bem que parecem sustentar todo o peso dessa enorme massa.

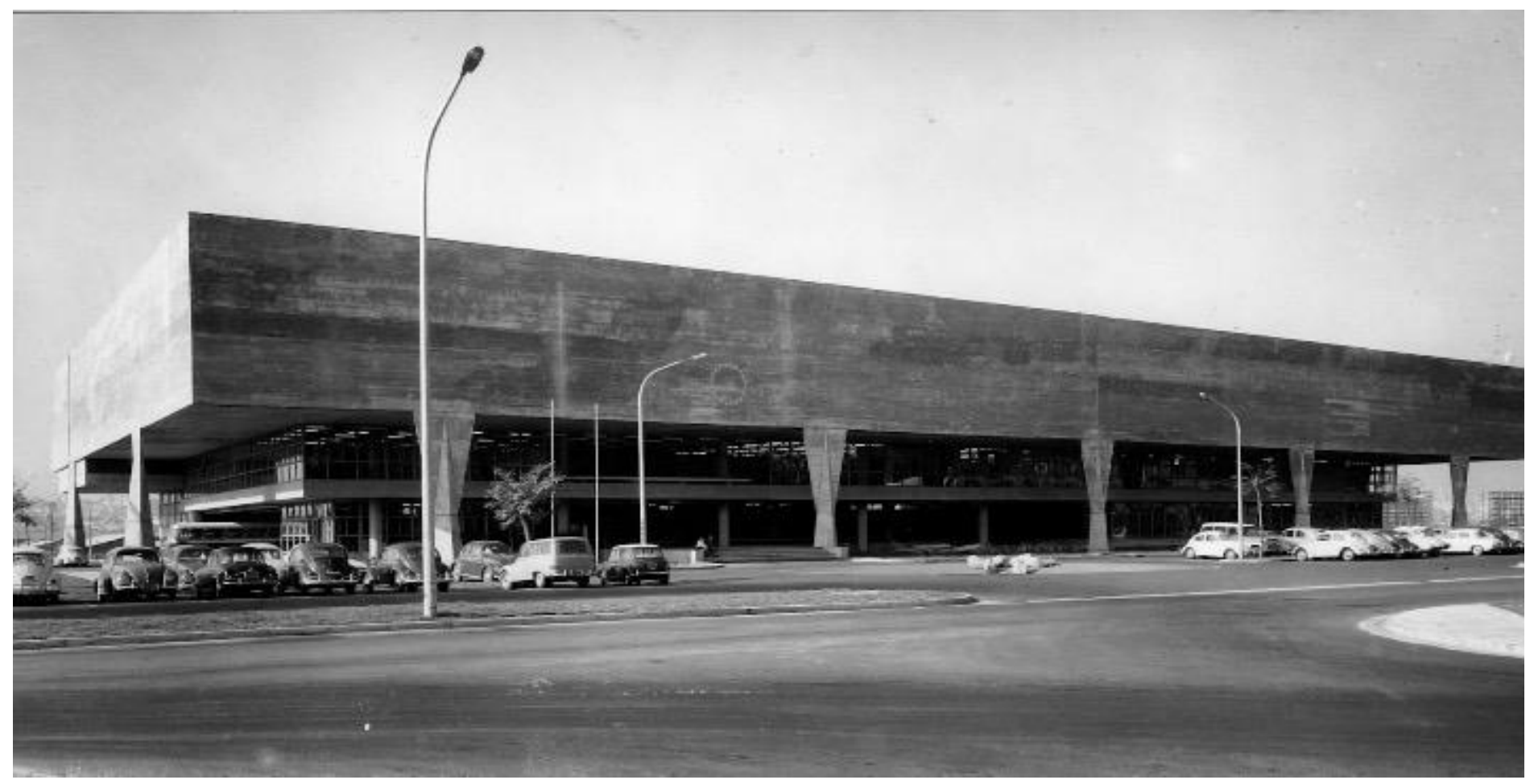

Figura 9 - FAU - USP - São Paulo/SP. Disponível em: http://200.144.182.66/acervo/items/show/42 
De fato, o contraste causado entre a finura dos pontos de apoio e a pesada carga que repousa sobre eles é estatizante. Quanto a parte interna ao edifício, Artigas utiliza um enorme vazio central medindo 15 metros, iniciado no subsolo e finalizado na cobertura, com grandes variações de andar para andar, produzindo desencontros e saliências entre os níveis, plantas com composições fluídas e às vezes canalizadas, ambientes dispostos de maneira cuja as divisões não constituem uma monótona continuidade, o que demonstra sua preocupação com o comunitário e a ausência de isolamentos, somente ambientes como salas de aula, anfiteatro, possuem um aspecto mais formal. ${ }^{10}$

"Segundo Sérgio Ferro: A renovação do Artigas foi mostrar que na arquitetura há uma enorme dimensão política que todo mundo esquece." ${ }^{11}$

Artigas deixou inúmeros de discípulos, que foram fascinados pela solidez de seus pensamentos e seu rigor doutrinário aliado a uma importantíssima compreensão humana, os maiores exemplos foram o arquiteto Joaquim Guedes e o mais conhecido Paulo Mendes da Rocha. ${ }^{12}$

\footnotetext{
10 lbidem, 2002, p. 300 a 303t

11 BASTOS, Maria Alice Junqueira. Pós-Brasília: Rumos da Arquitetura Brasileira. São Paulo: Ed. Perspectiva/FAPESP, 2003, p.15

12 lbidem, 2002, p. 305 e 306.
} 


\subsubsection{José Galbinski na UNB e o surgimento de uma vertente brasiliense}

O brutalismo paulista foi um movimento que ocorreu simultaneamente à construção de Brasília, já que suas primeiras manifestações apareceram em meados da década de $1950 .{ }^{13}$ Com o surgimento da cidade moderna de Brasília, Niemeyer trouxe em seus projetos a liberdade formal, o uso do concreto aparente, o monumentalismo, a estrutura como definidora da forma, com isso, um novo valor dado a estrutura. ${ }^{14}$

[...] Foi-se configurado ao longo dos anos de 1970, um quadro em que um "modelo" arquitetônico tornou-se predominante e cada vez mais ancorado numa retórica, substituta dos ideais que inspiraram os primeiros projetos.

Durante essa década até os anos de 1980 houve uma institucionalização da arquitetura do concreto aparente e a forte presença de empenas nos projetos. ${ }^{15}$

Surgem então por volta dos anos 70 evidências brutalistas nos projetos do arquiteto José Galbinski, na época coordenador do curso de Arquitetura e Urbanismo da Unb.

\footnotetext{
13 Ibidem, 2003, p. 9.

14 Ibidem, 2003, p. 7.

15 Ibidem, 2003, p. 43.
} 


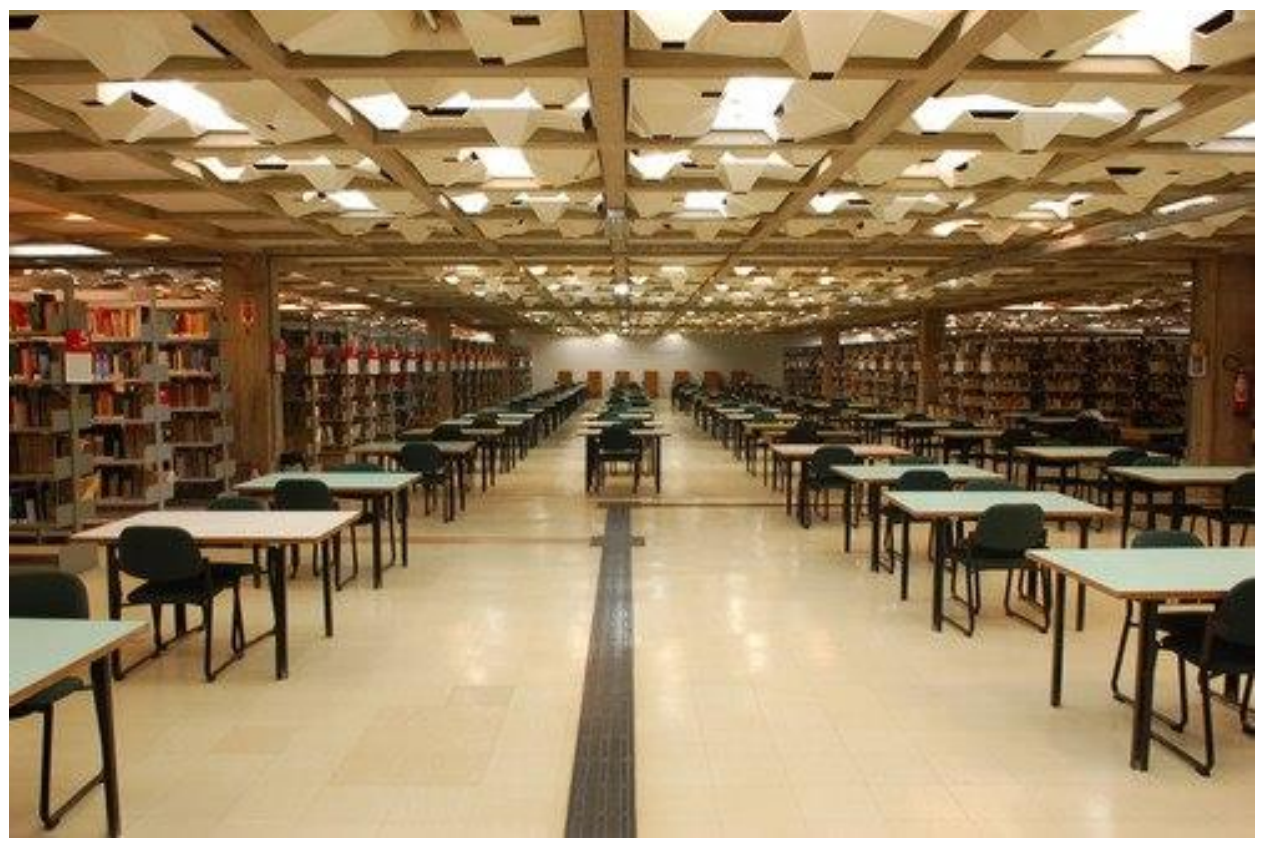

Figura 11 - Interior Biblioteca Central - UNB - Brasília/DF. Disponível em: https://www.facebook.com/unb.bce/photos/a.377843695595853.82350.19591353712220 4/1095713223808893/?type=1\&theater

urbanístico do Pontão do Lago Sul, e mais recentemente dos projetos Campus do Cérebro, IINN-Instituto Internacional de Neurociência de Natal - Macaíba/RN (2006).. ${ }^{16}$

${ }^{16}$ STENZEL, Emilia, 50 Anos de Arquitetura. Editora Senac/Anual, Brasília, 2010, p. 208. 


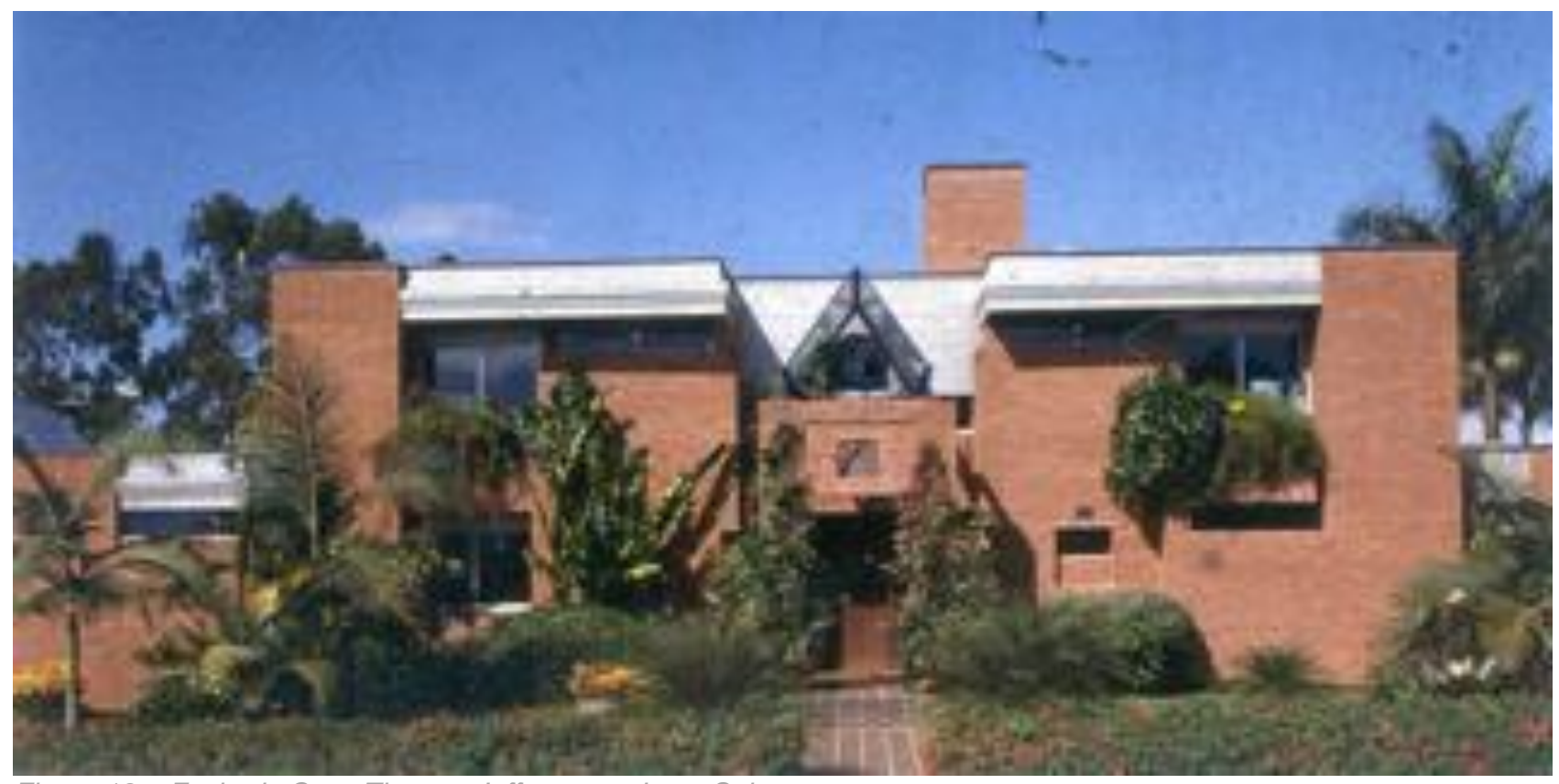

Figura 13 - . Fachada Casa Thomas Jefferson no Lago Sul Brasília/DF. Arquivo NDP - UniCEUB

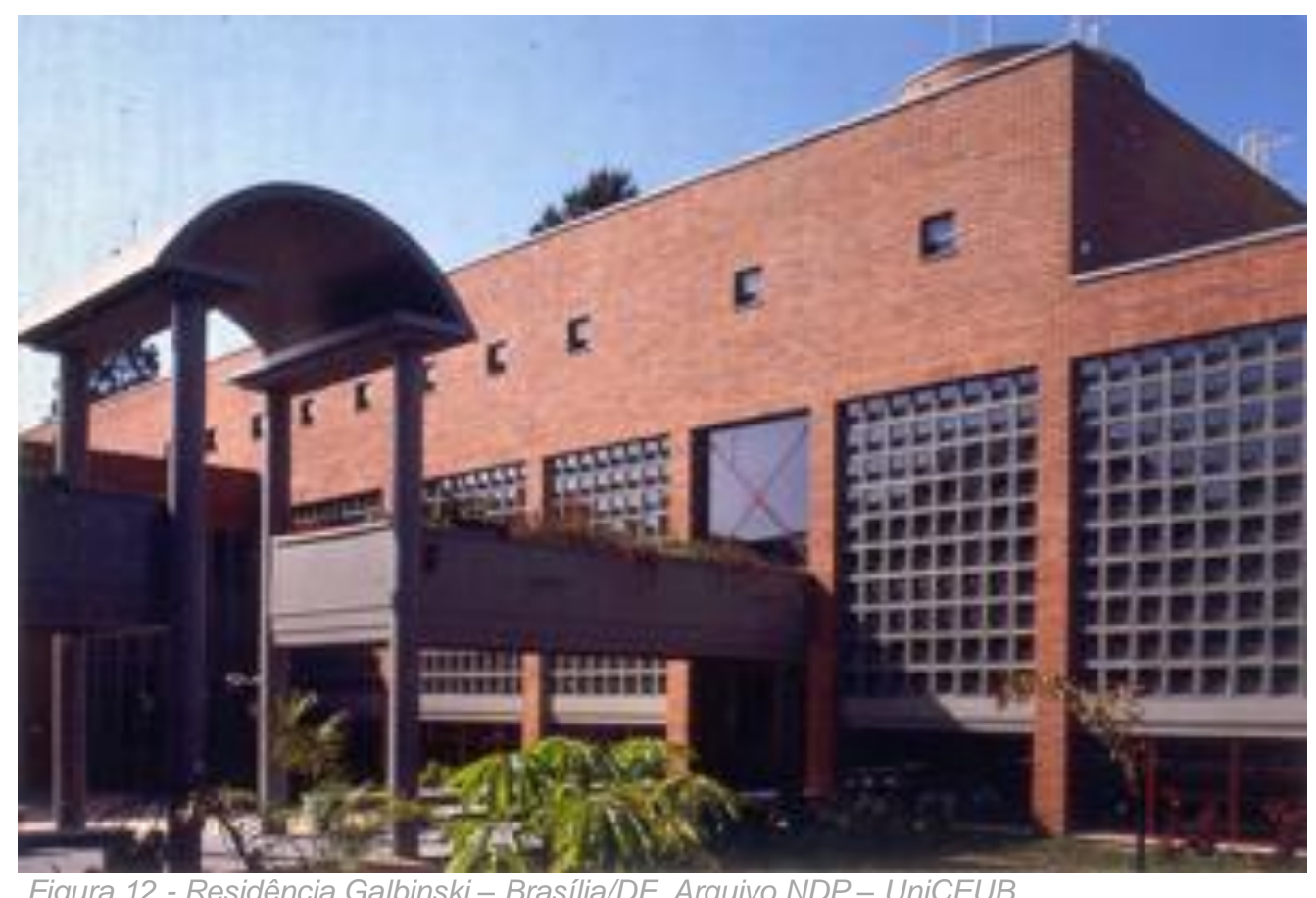

Figura 12 - Residência Galbinski - Brasília/DF. Arquivo NDP - UniCEUB 


\section{Desenvolvimento}

\subsection{Definição das Variáveis Morfológicas e Espaciais}

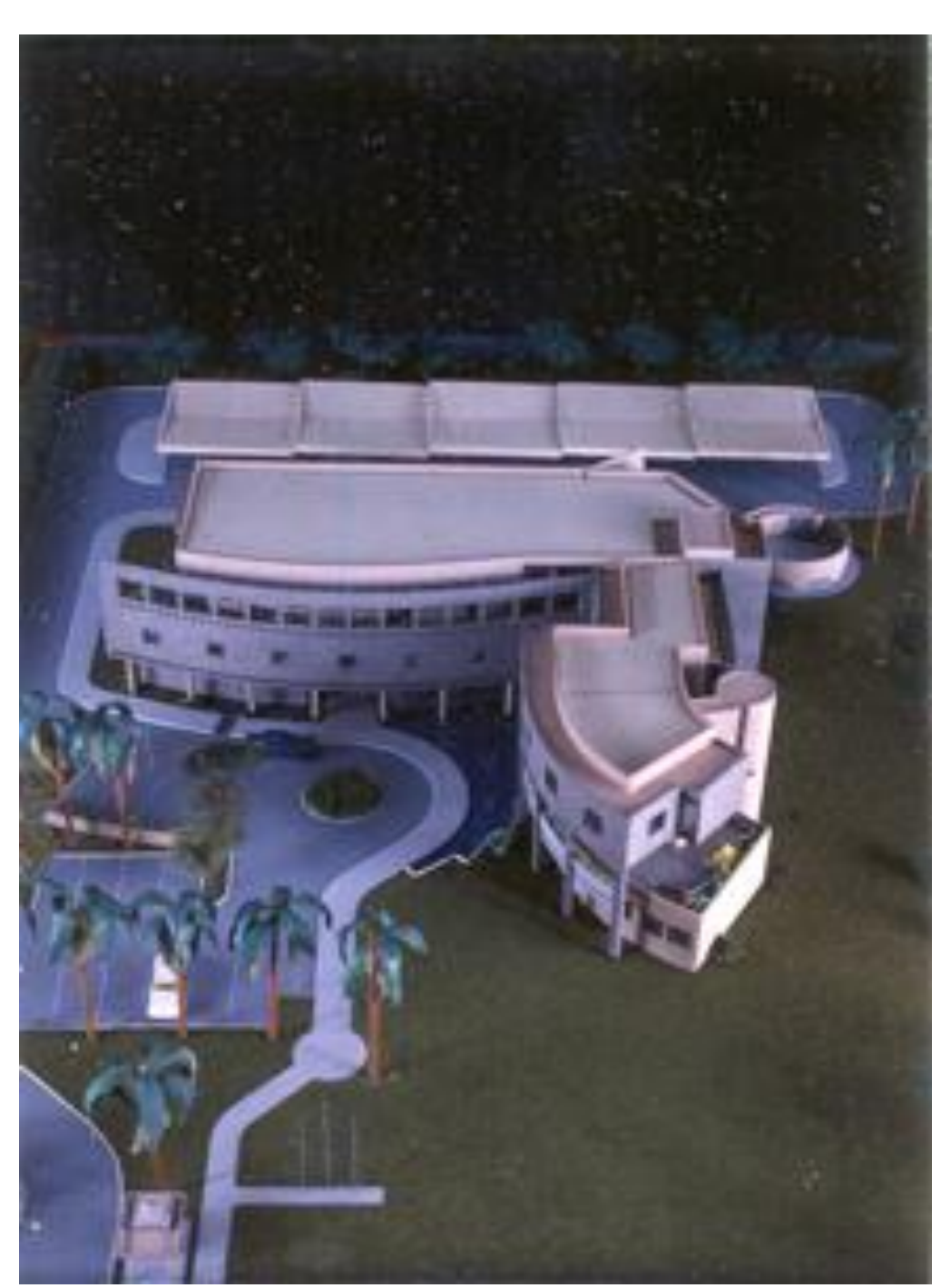

\section{Ambos}

os projetos

estudados nesta pesquisa são representativos da arquitetura brutalista brasiliense, fortimente configurada por uma contribuição de José Galbinski para

0
desenvolvimento de um repertório local. A análise do trabalho possui um caráter comparativo, no sentido de evidenciar aspectos comuns, identificadores da linguagem do arquiteto.

Figura 14 - Maquete Sede do Banco Interamericano de Desenvolvimento (BID). Arquivo NDP - UniCEUB 


\section{* restaurante}

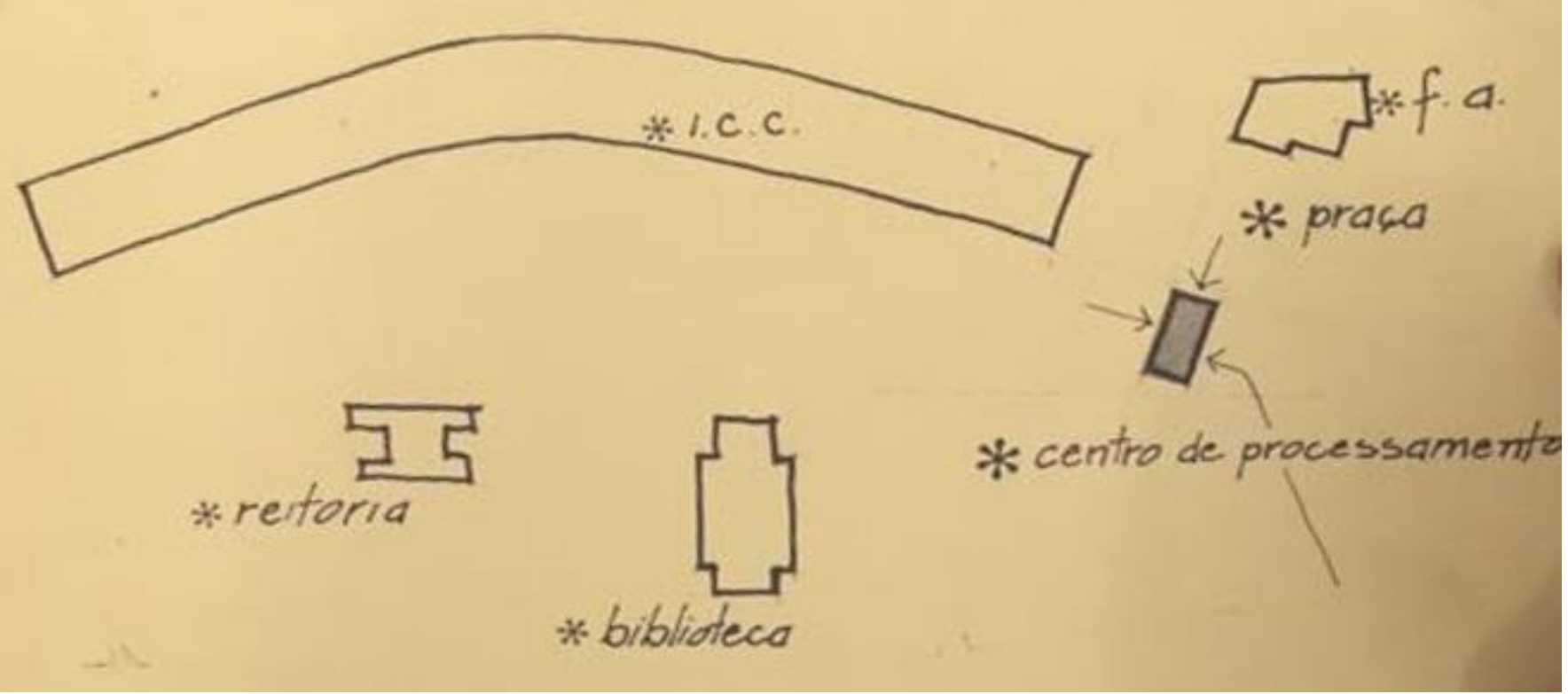

Figura 15 - Foto do croqui original do arquiteto indicando a localização do CPD. Arquivo NDP - UniCEUB

O projeto do Centro de Processamento de Dados (CPD) foi realizado no ano de 1982, o edifício seria implantando em um terreno no Campus da UnB, mas por questões internas à universidade não foi construído.

O Restaurante Universitário (RU), foi inaugurado em 1975 e está localizado na parte superior do minhocão no Campus Darcy Ribeiro - UnB. 


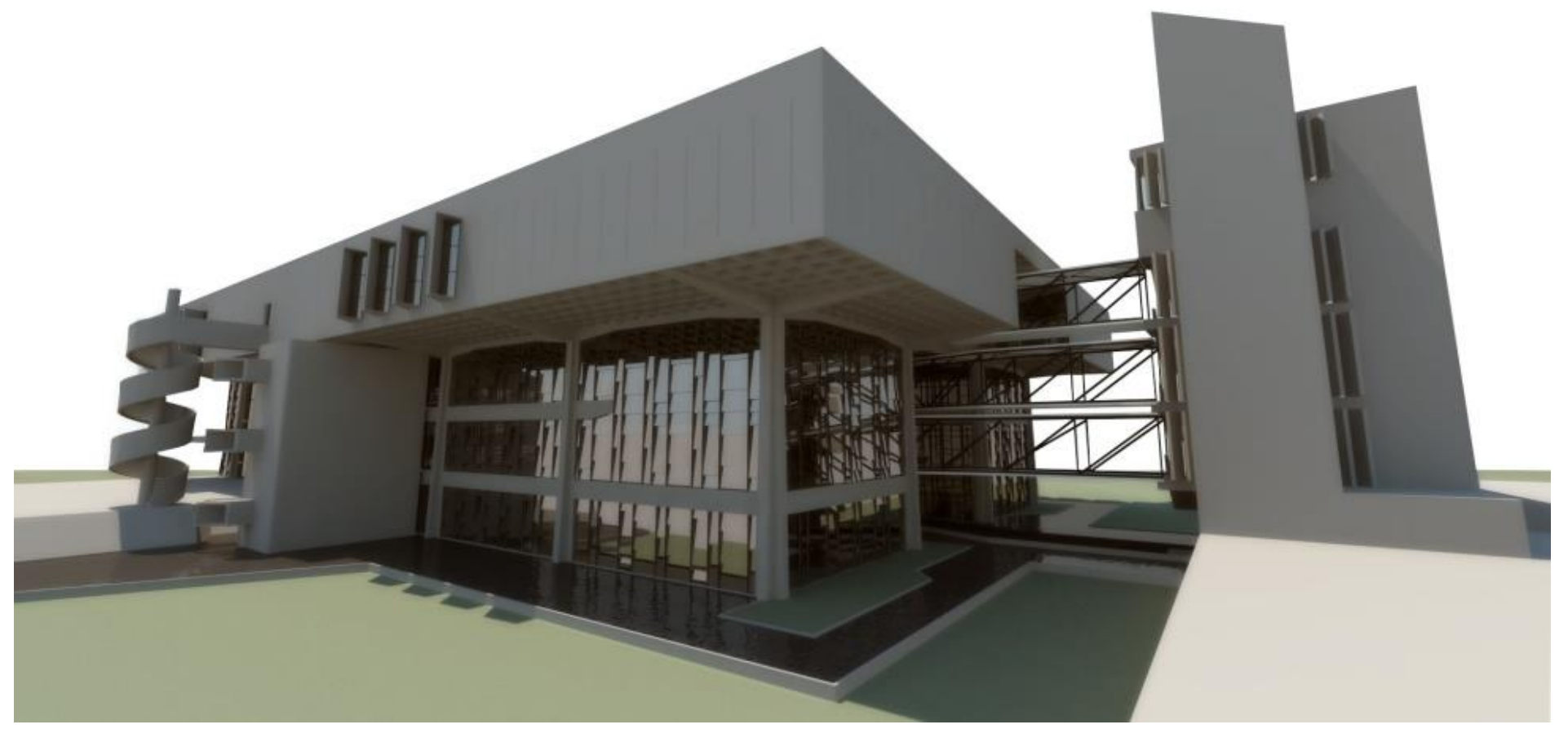

Figura 16 - Maquete eletrônica do RU. Arquivo NDP - UniCEUB

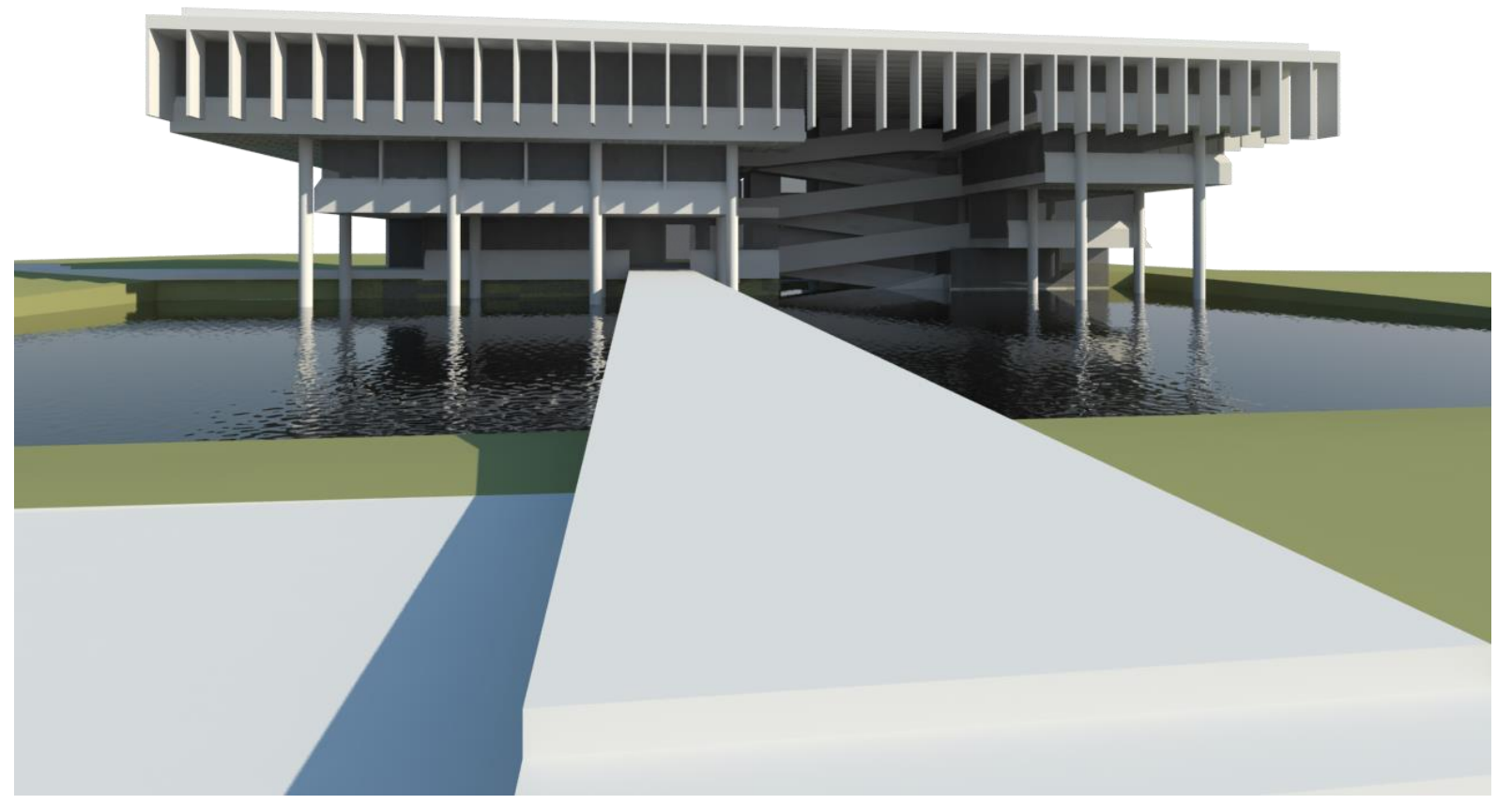

Figura 17 - Maquete eletrônica do CPD. Arquivo NDP - UniCEUB 


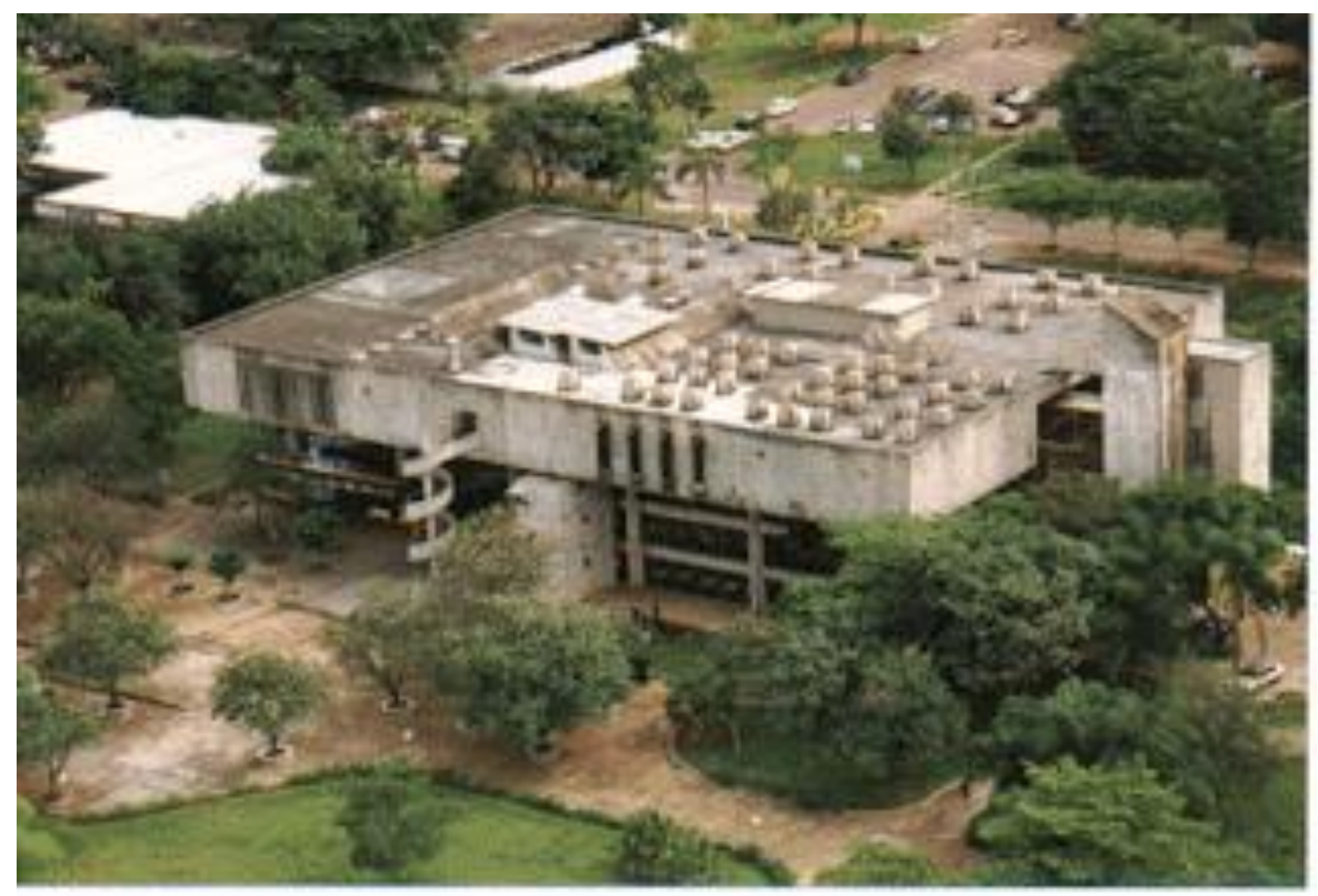

Figura 19 - Foto aérea RU. Disponível em: http://reconstruindoocotidiano.blogspot.com.br/2007/08/sobre-orestaurante-universitrio-e.html

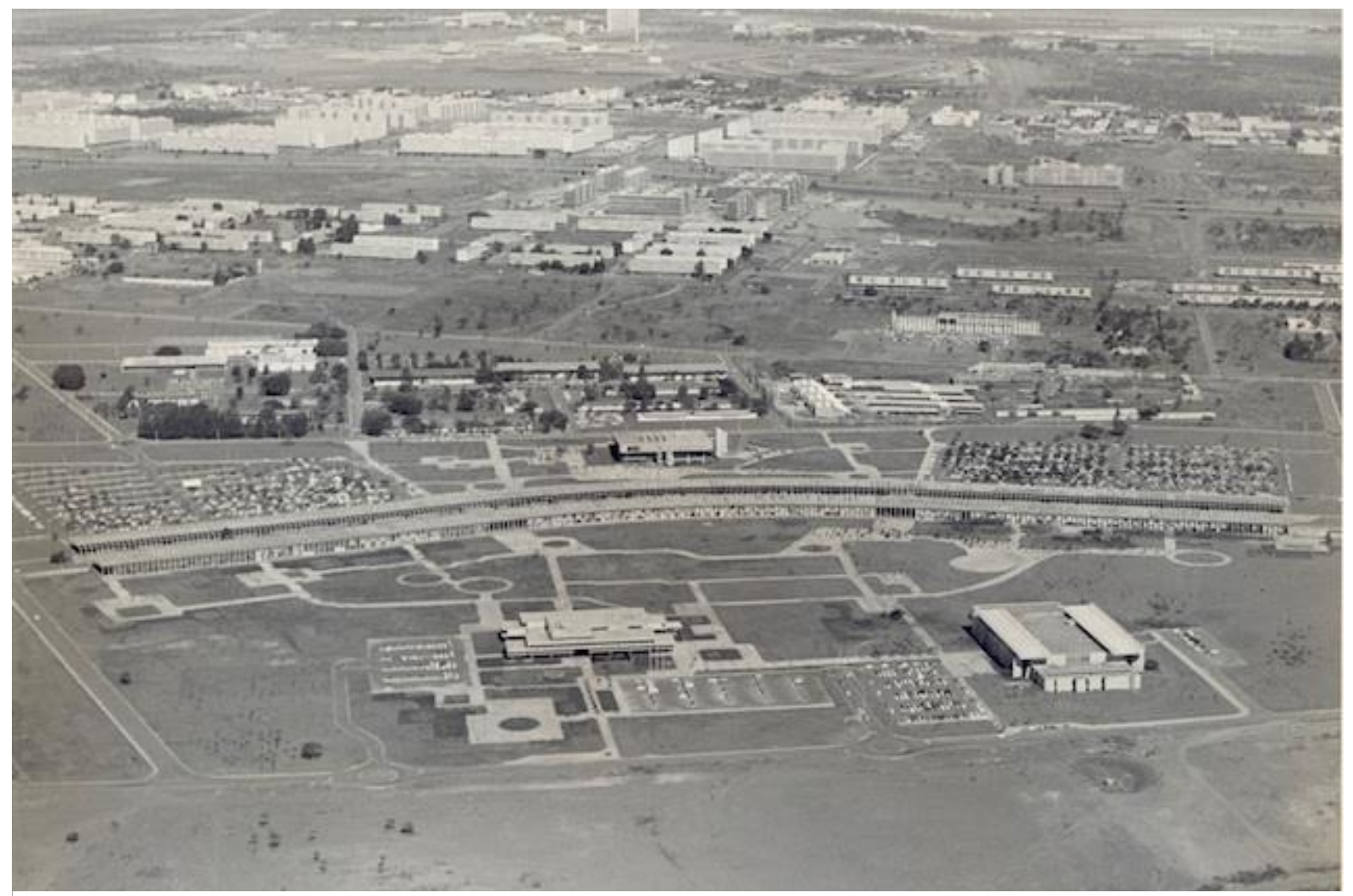

Figura 18 - Campus Darcy Ribeiro - década 70/80. Disponível em:

http://campus.fac.unb.br/arquivo/campus12014/universidade/item/2213-especial-arquitetura-na-universidade-de- 


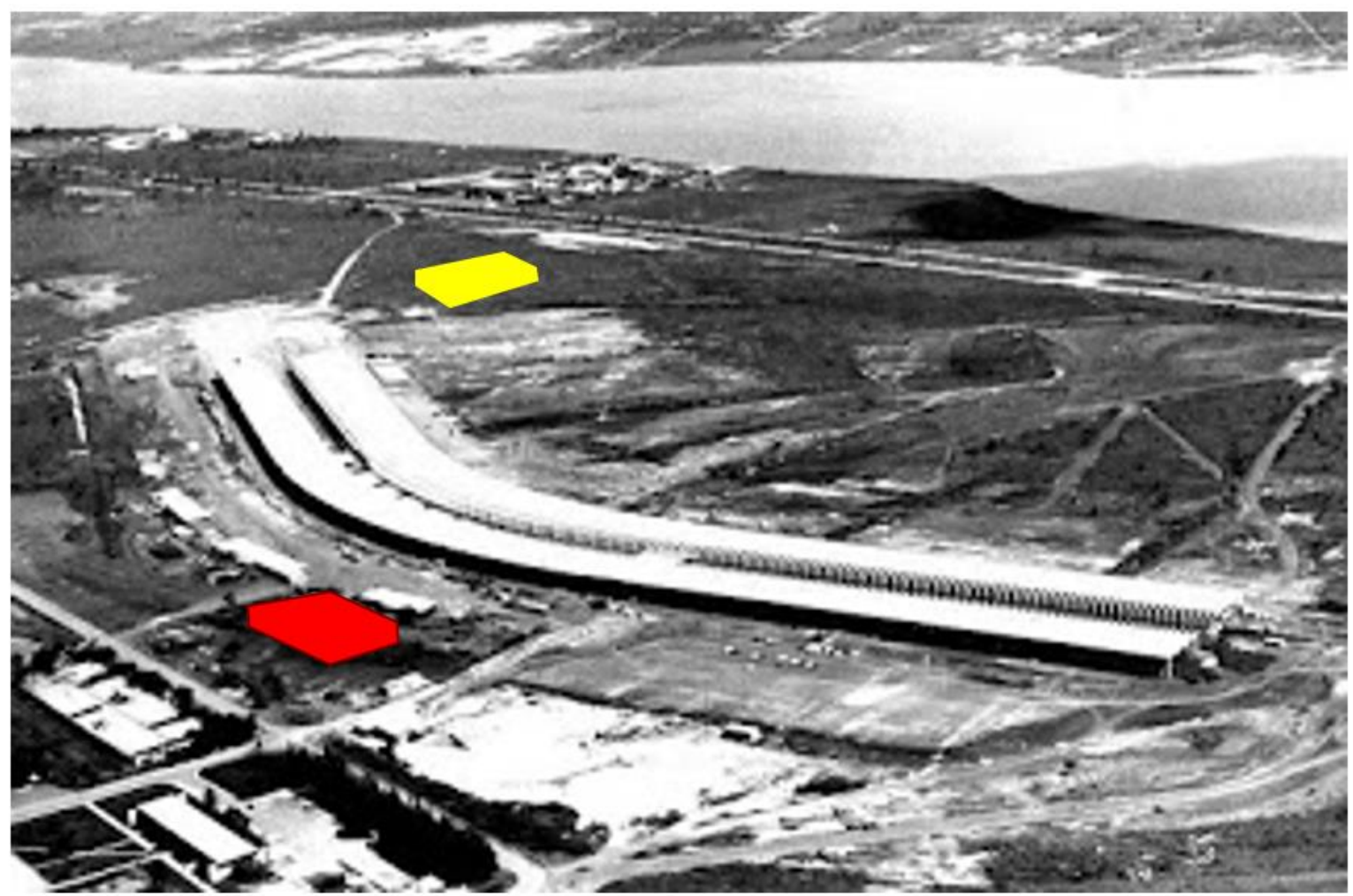

Figura 20 - Foto com indicação da localização do RU (vermelho) e CPD (amarelo). Foto original disponível em: http://imoveldf.blogspot.com.br/2013/10/construcao-de-brasilia-brasil.html?view=magazine 
Analisado por meio de diagramas as variáveis projetuais que orientaram o trabalho do arquiteto, é possível identificar não apenas suas características formais, mas alguns elementos e procedimentos de projeto inovadores, que se mantem atuais. $O$ leque de diagramas definidos para análise foram os que seguem:

[ Configuração de pavimentos

[ Relação Laje e Cobertura

[ Relação espelho dágua

[ Circulação vertical

[ Imersão e Evasão

[ Estrutura

[ Abertura zenital

[ Tipos de fechamentos

[ Topografia 
2.1.1. Configuração de pavimentos

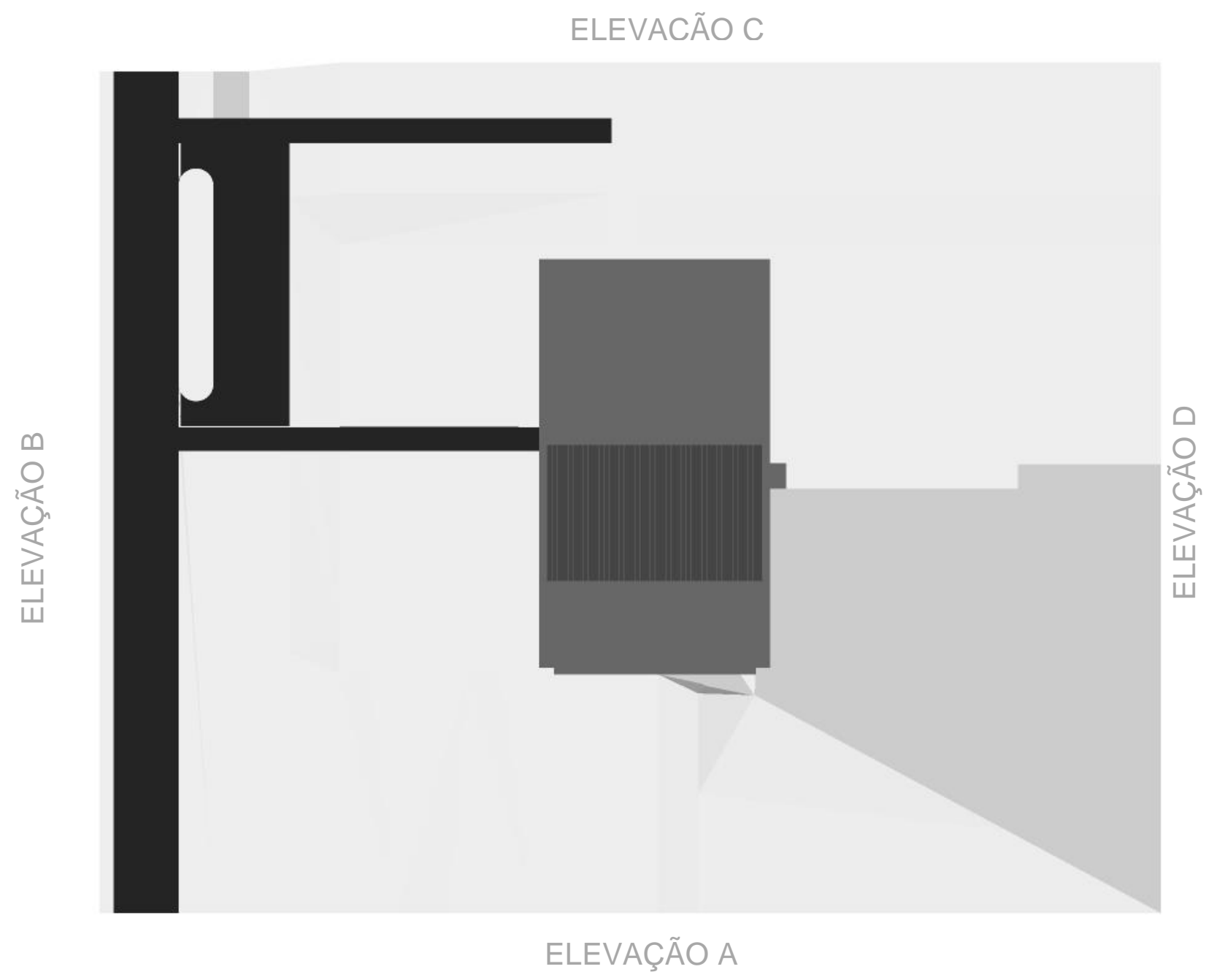

Figura 21 - Diagrama da vista superior do CPD 
Laje superior

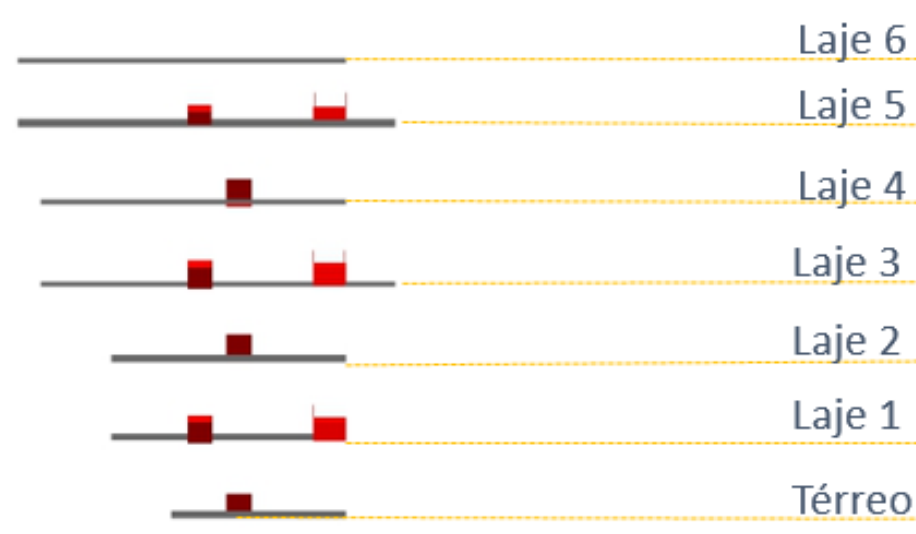

|| $\mid$

Pilares

Terreno

| | | | | | Pilares

Subsolo

Os patamares amplificam sua largura conforme elevam os níveis e são mais protuberantes na face da ELEVAÇÃO B, porém no Subsolo o ressalto é maior, o que não compromete a volumetria.

Os vínculos dos níveis são as rampas e escadas, todos mais próximos da ELEVAÇÃO D.

Diferente dos pilares do subsolo, os do restante da edificação são esbeltos e contínuos, 4 filas, no subsolo apenas 6 . 
Laje superior

Laje 6

Laje 5

Laje 4

Laje 3

Laje 2

Laje 1

Térreo

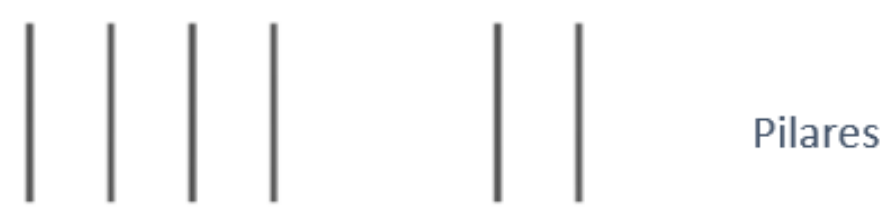

Terreno

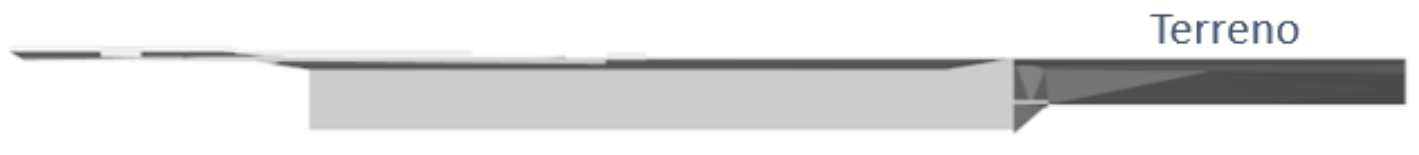

Pilares

Subsolo

Figura 23 - Diagrama pavimentos - Elevação B do CPD

Os patamares estão praticamente alinhados ao lado direito, porém, sofrem um aumento em sua largura à proporção que eleva o nível. Todas as conexões (rampas, escadas e pilares) permanecem alinhadas.

Referindo-se aos pilares, notamos a forma simples das 6 séries que vencem todas as lajes e vãos. 
Laje superior

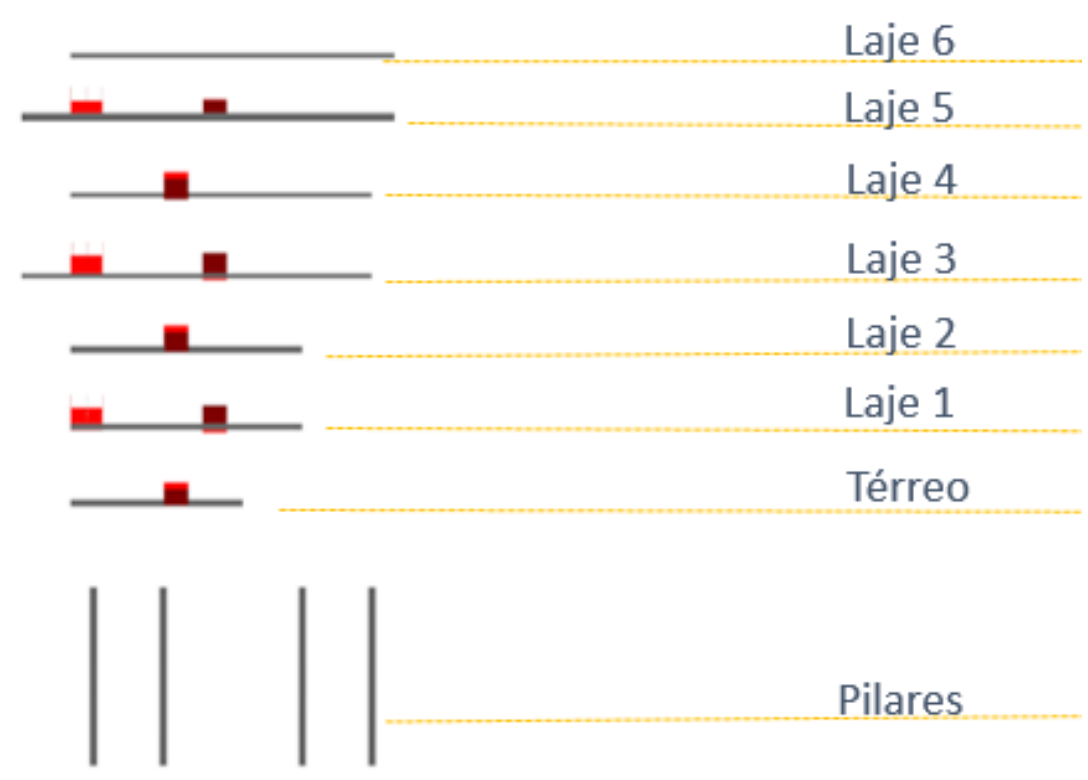

Terreno

Pilares

Subsolo

Figura 24 - Diagrama pavimentos - Elevação C do CPD

Esta vista configura o espelho da elevação A. Fora o terreno e a aproximação dos patamares. 
Laje superior

Laje 6

Laje 5

Laje 4

Laje 3

Laje 2

Laje 1

Térreo

Pilares
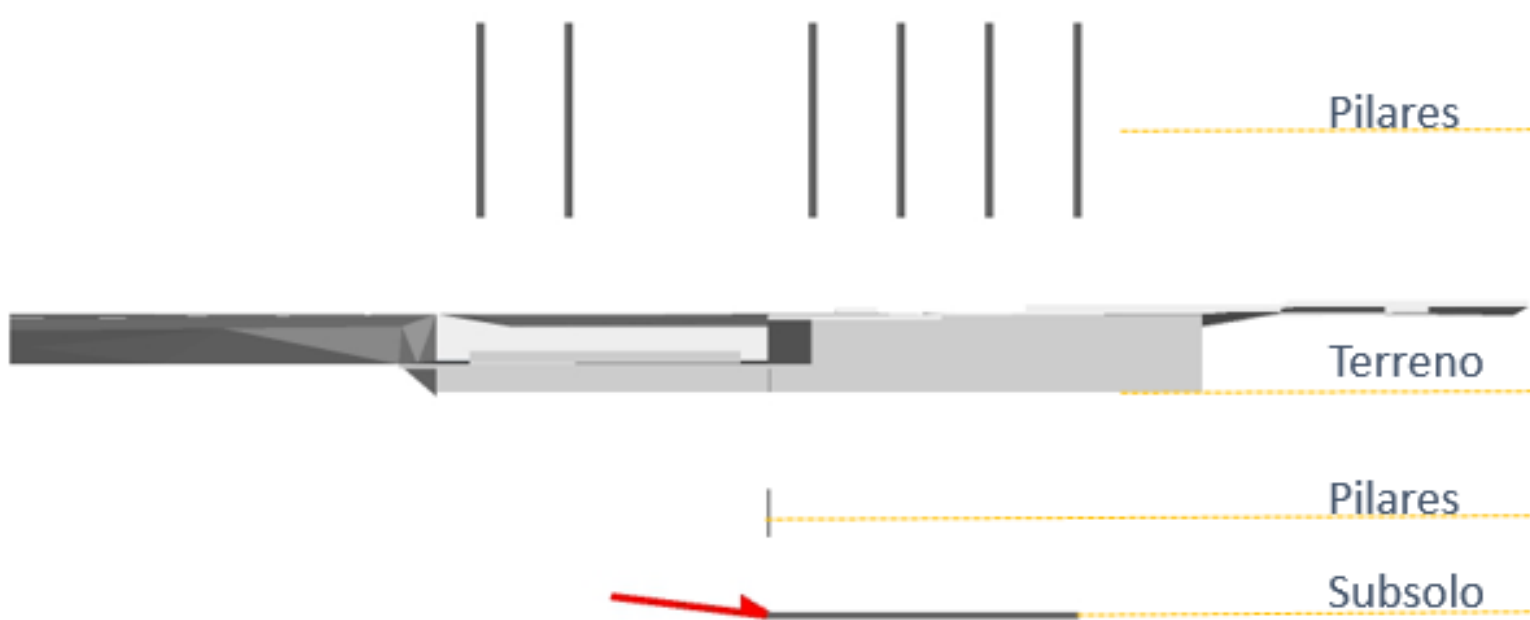

Figura 25 - Diagrama pavimentos - Elevação D do CPD

Exceto o terreno e a direção dos patamares, esta vista é o espelho da elevação B. 

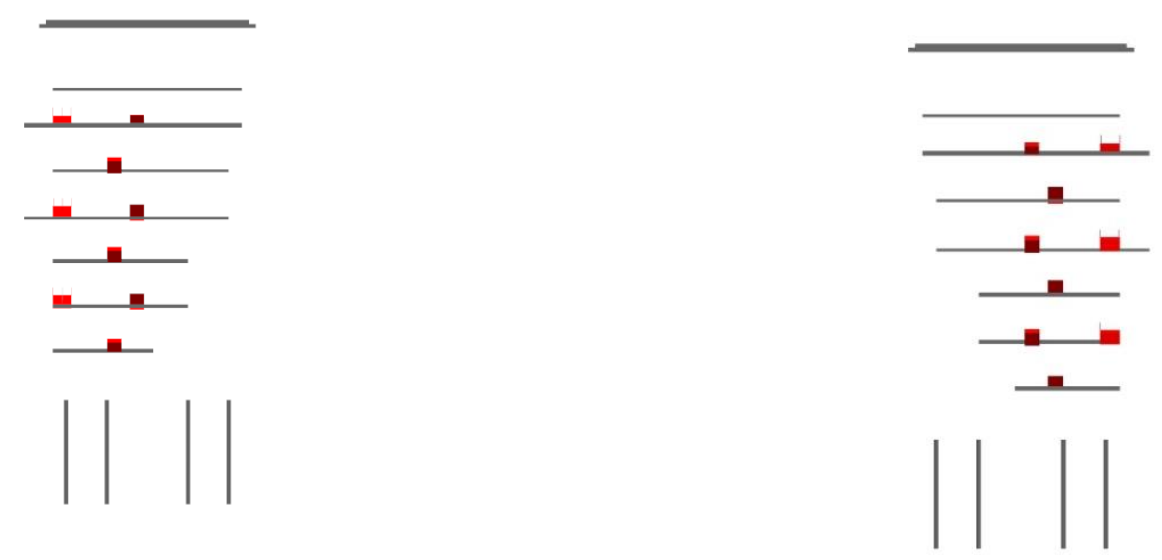

||||||
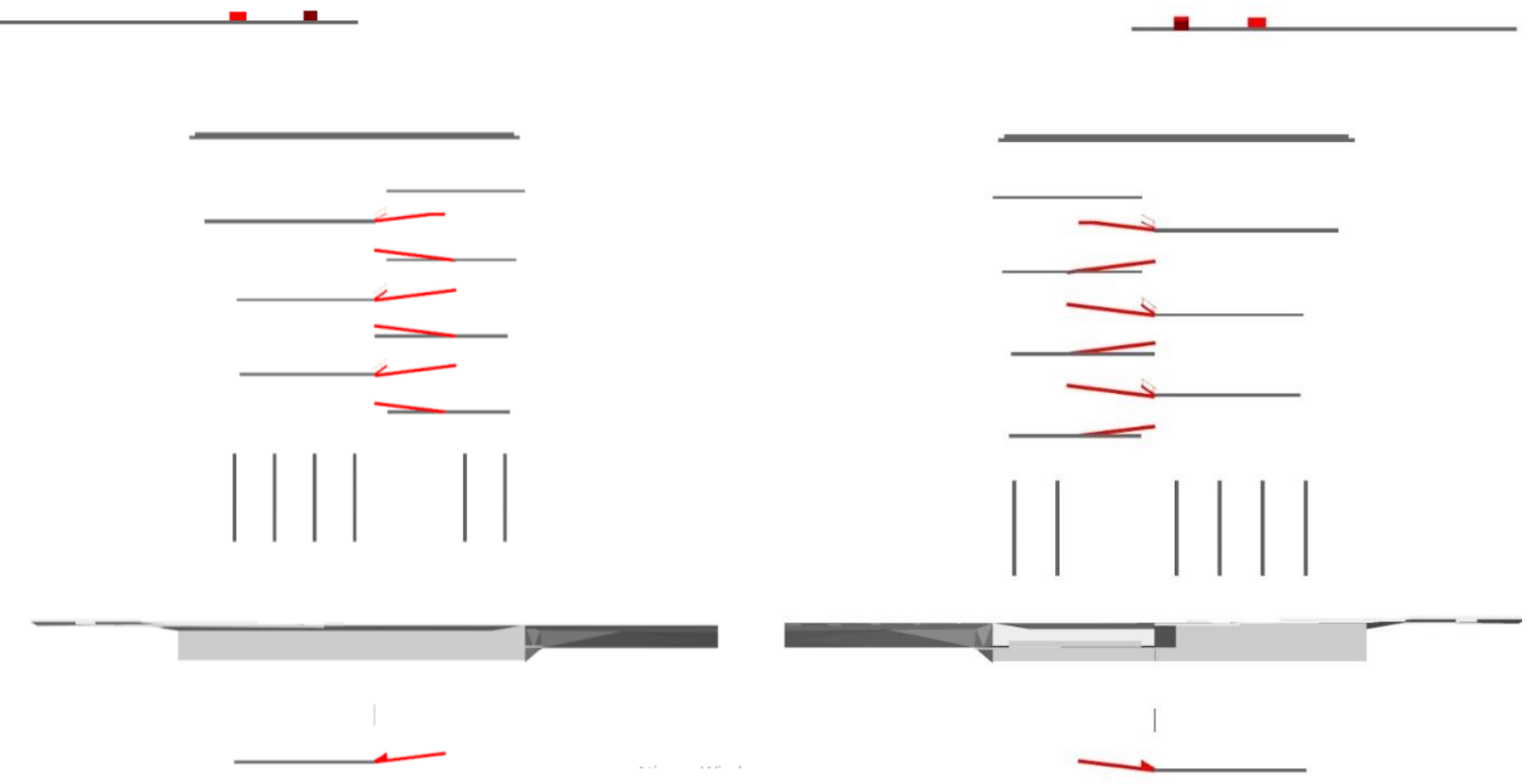

Figura 26 - Diagramas das elevações A, C, B e D do CPD 
ELEVAÇÃO C

悉

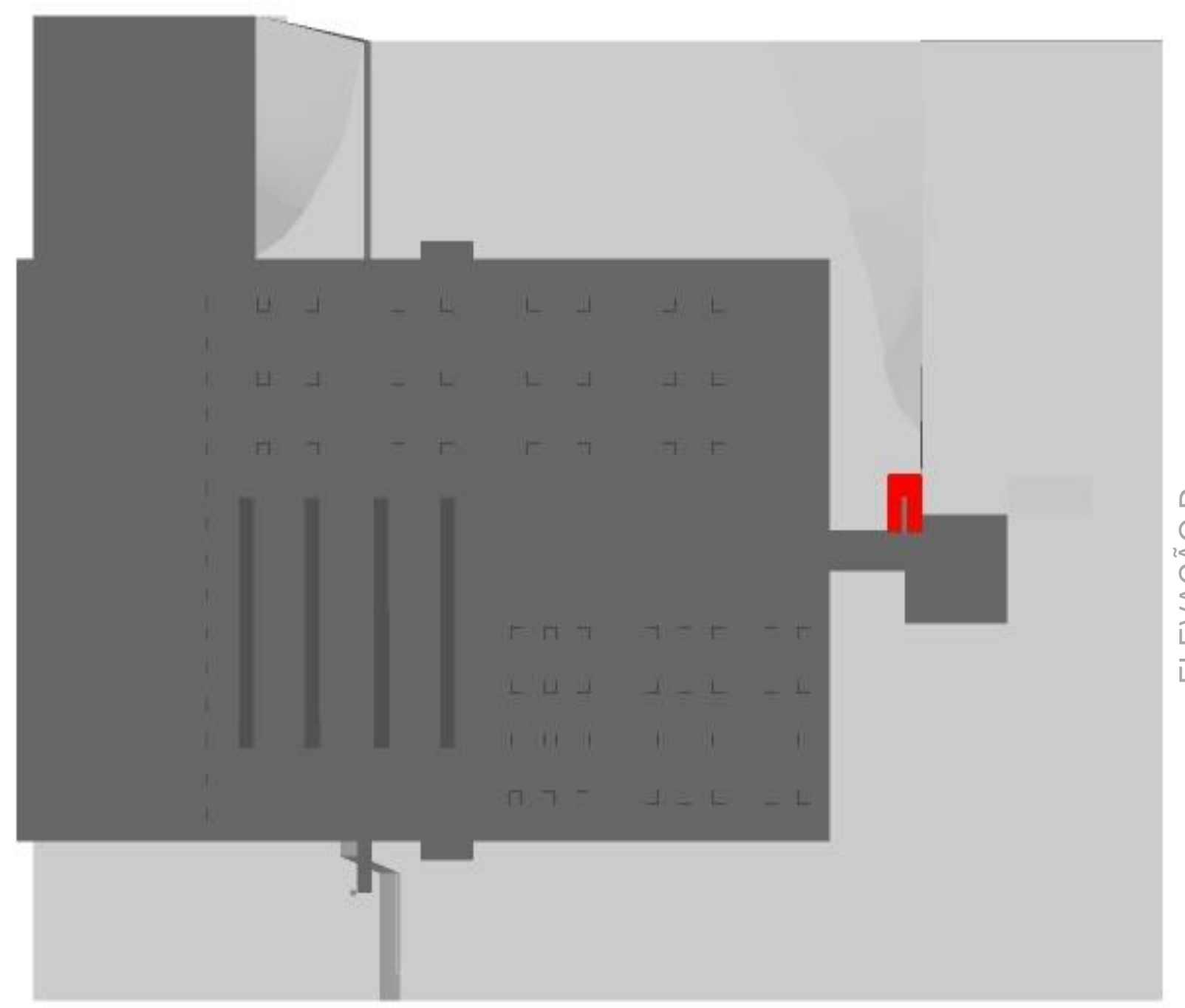

ELEVAÇÃO A

Figura 27 - Diagrama da vista superior do $R U$ 


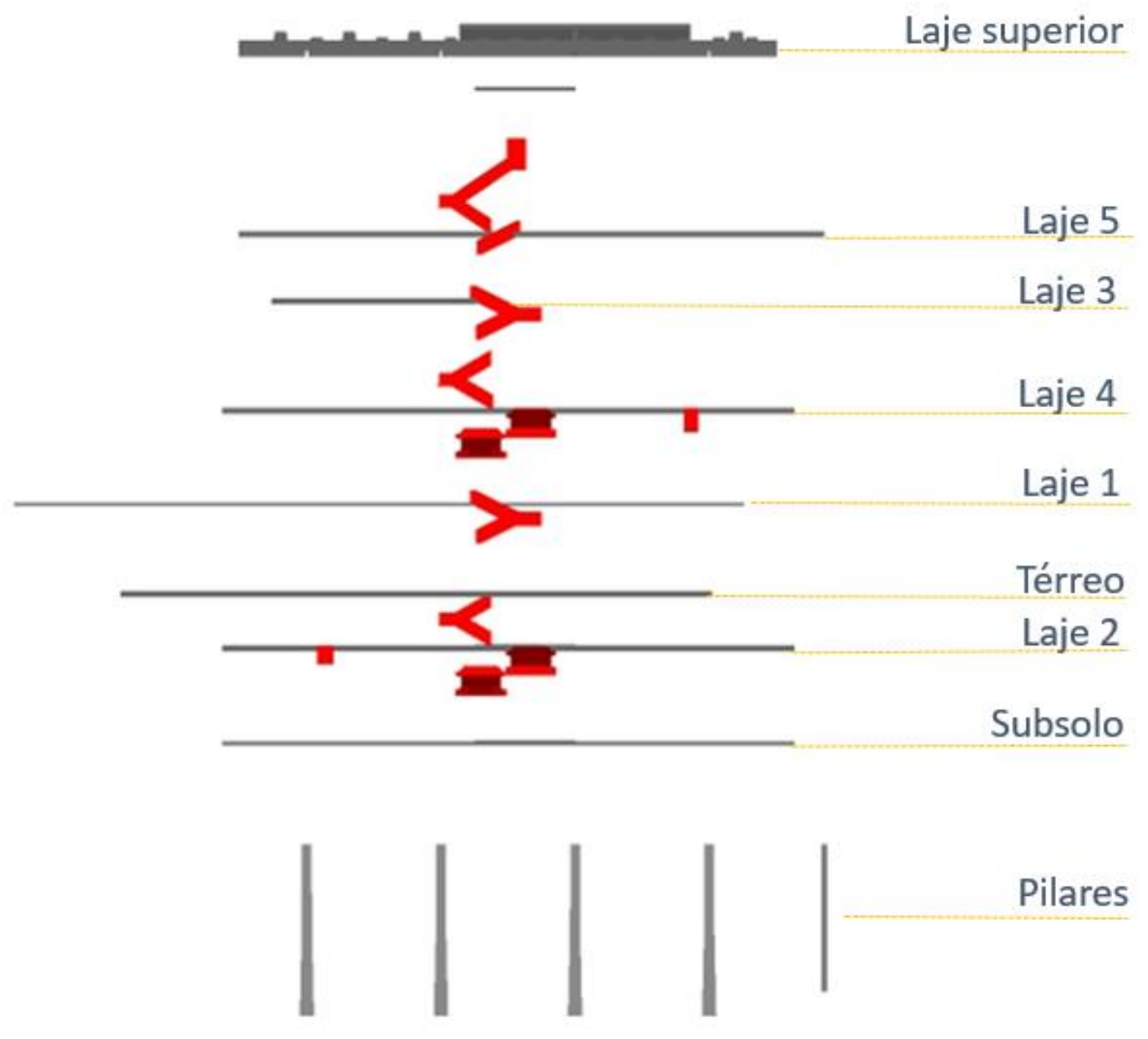

Terreno

Figura 28 - Diagrama pavimentos - Elevação A do RU

Nesta cena, conseguimos enxergar de forma mais clara o desencontro racional dos patamares e a preocupação em proporcionar amplitude. 
Laje superior

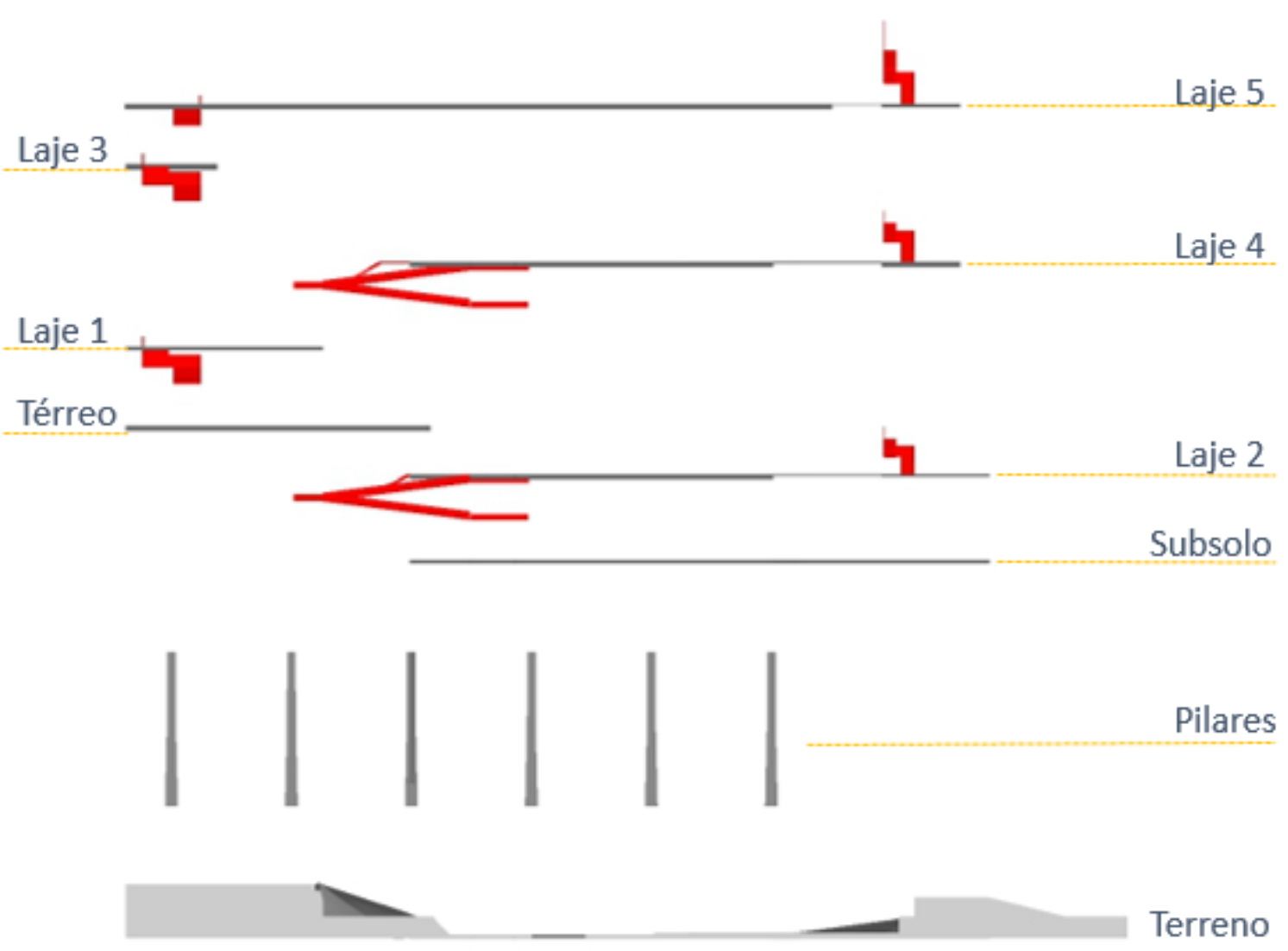

Figura 29 - Diagrama pavimentos - Elevação B do RU

A circulação vertical é alinhada, à exceção de duas escadas colaterais.

Deste ponto de vista as lajes têm a largura símil, desencontradas, o que conecta são as circulações e os pilares contínuos. 
Laje superior

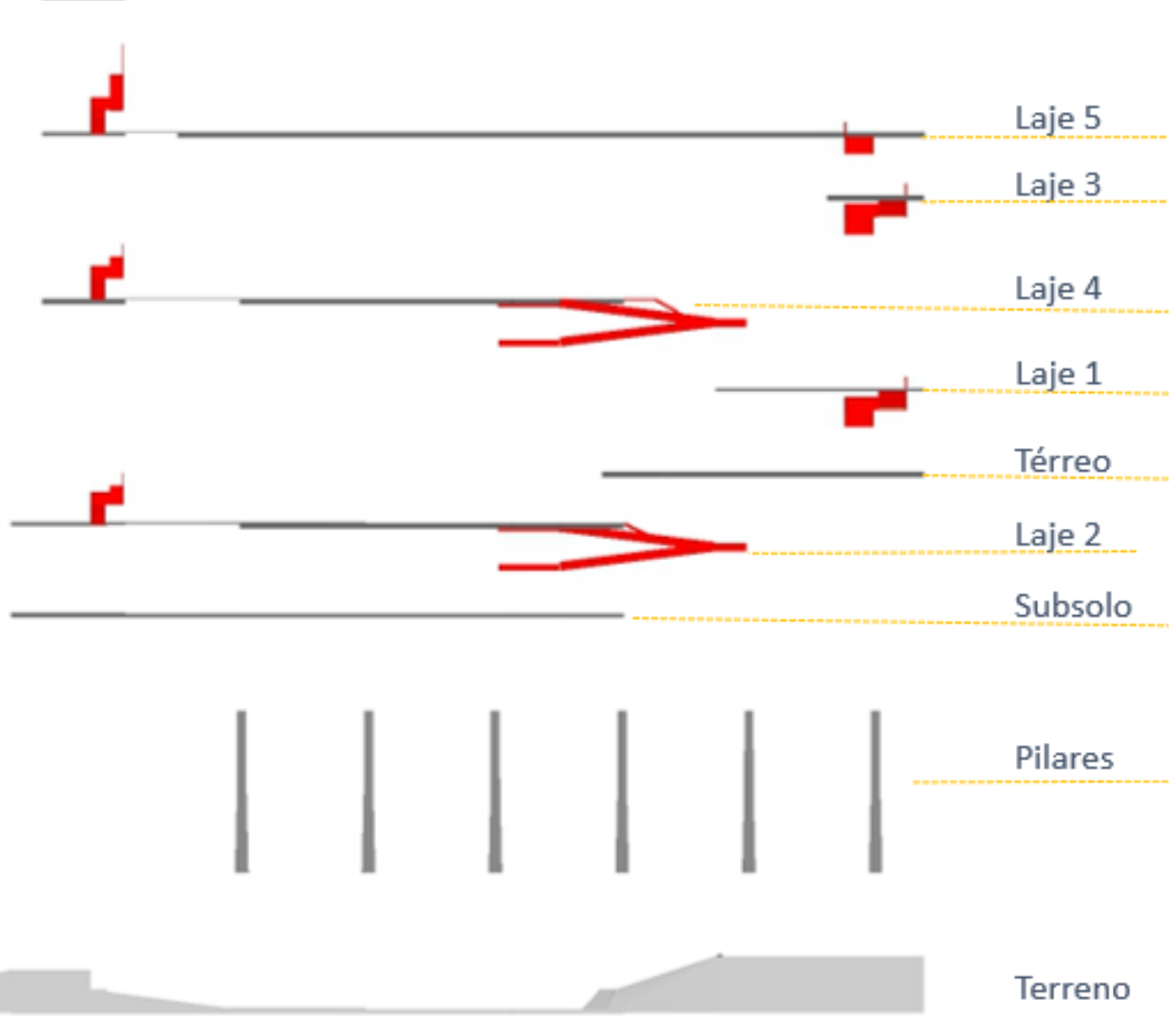

Figura 30 - Diagrama pavimentos - Elevação C do RU

Excerto o terreno, esta vista é o espelho da elevação $A$.

Para o observador no local a simetria não é notada com tanta facilidade, pois o terreno é acidentado. 


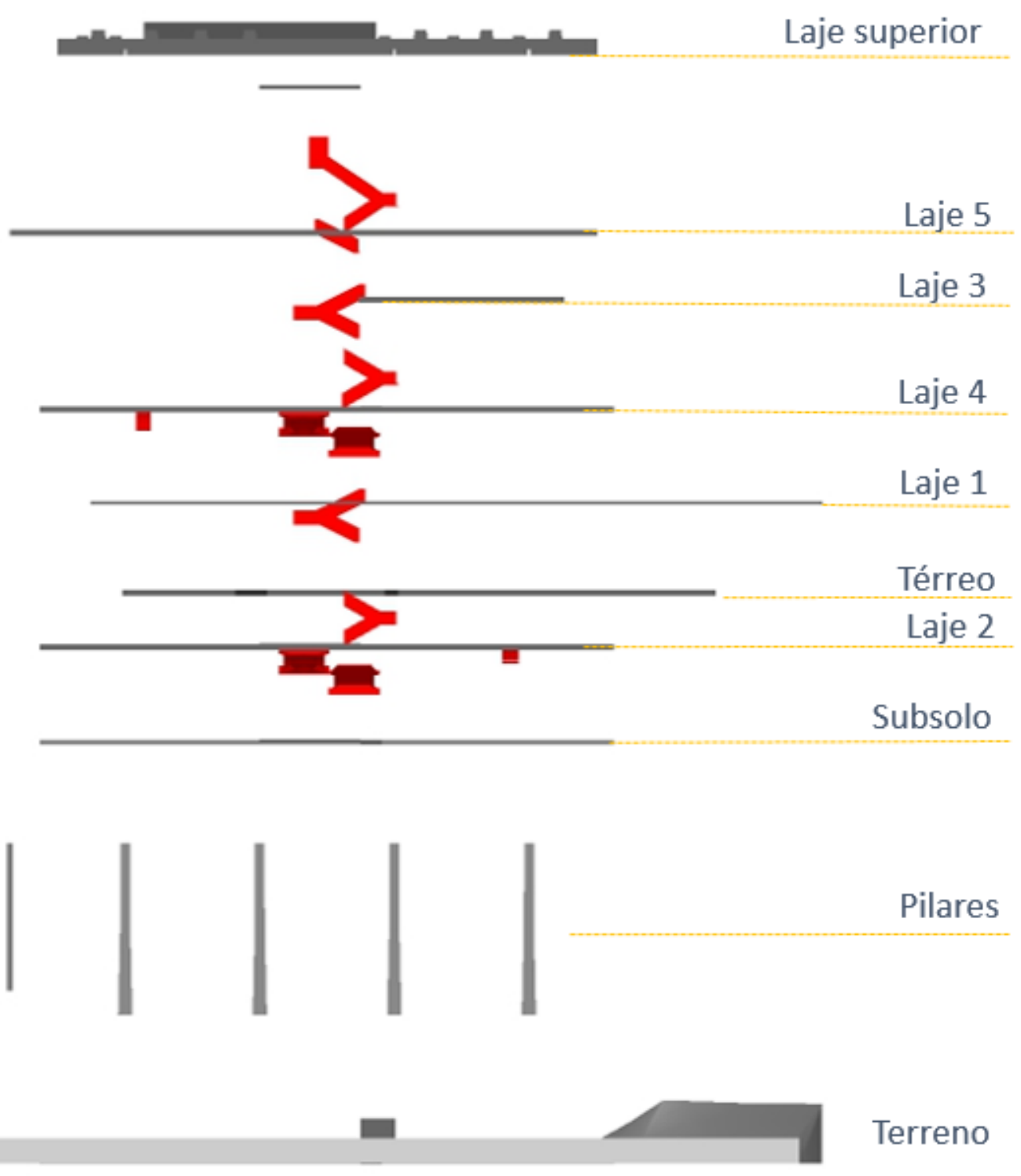

Figura 31 - Diagrama pavimentos - Elevação D do RU

Esta cena é o espelho da elevação $B$, salvo o terreno e a aproximação desses patamares. 

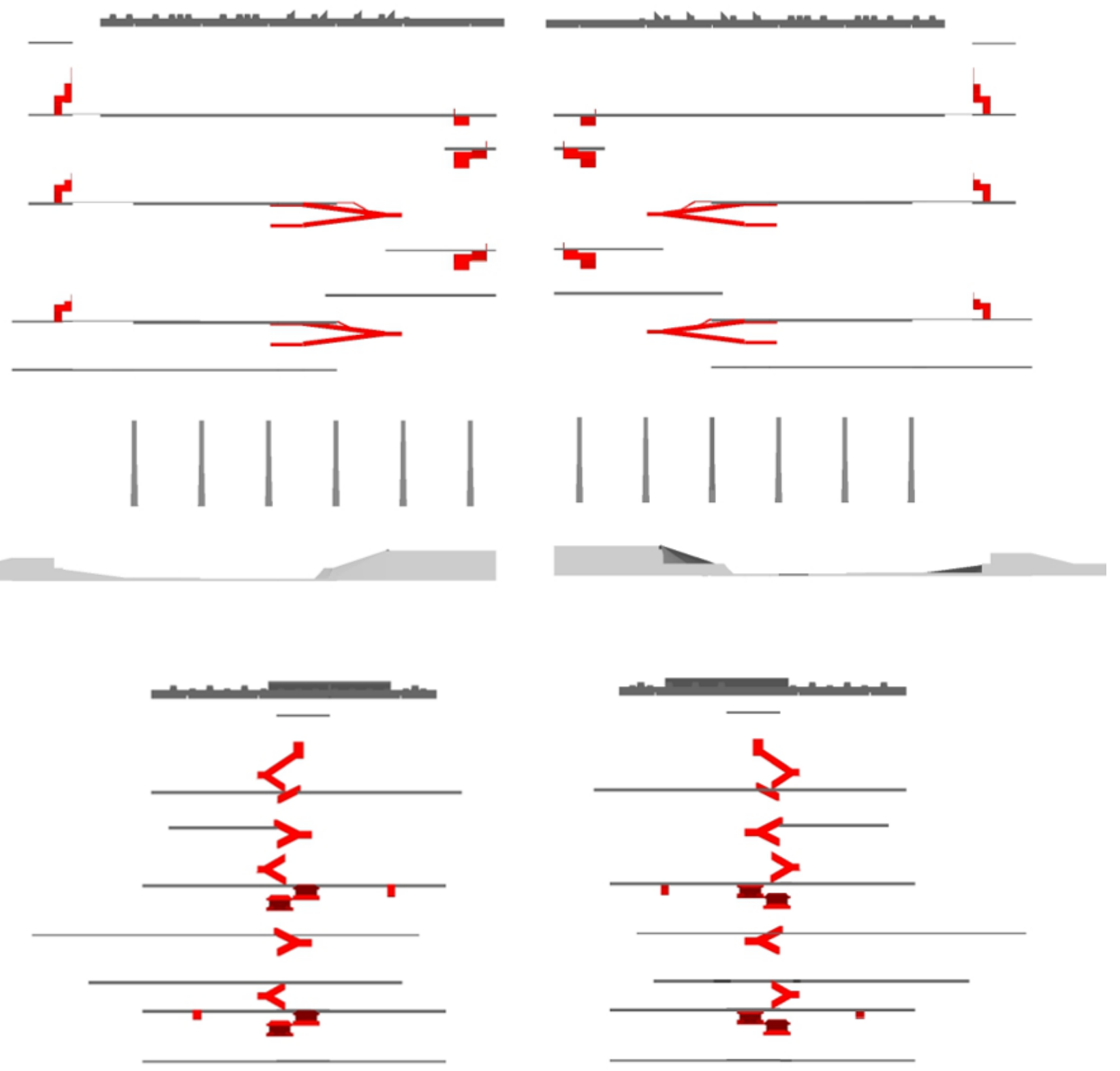

$$
|| \mid
$$
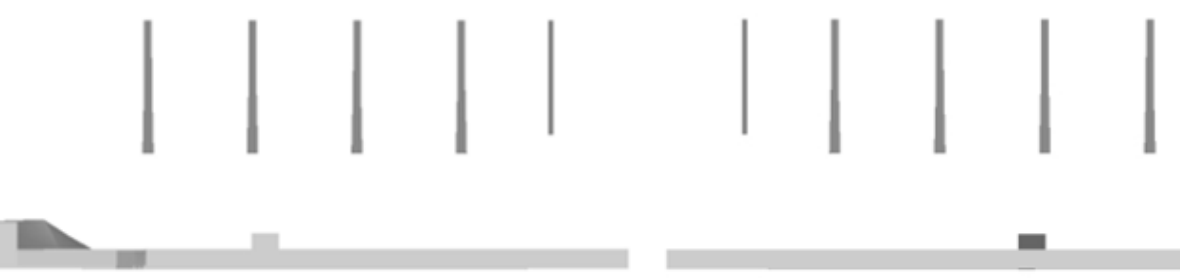

Figura 32 - Diagramas das elevações $A, C, B$ e D do RU 


\subsubsection{Relação Laje e Cobertura}

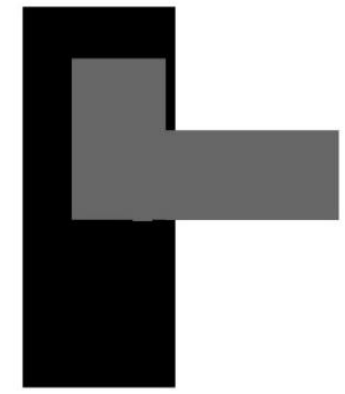

Subsolo

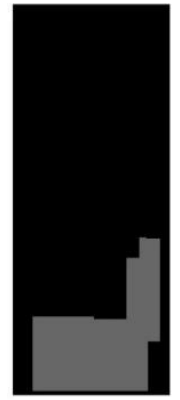

Laje 4

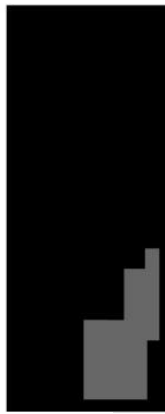

Térreo

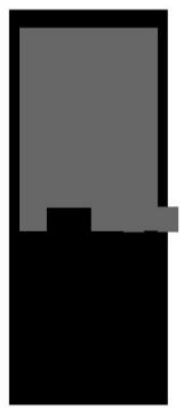

Laje 5

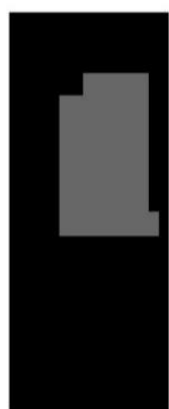

Laje 1

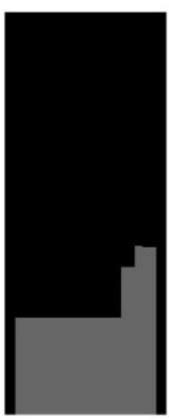

Laje 6

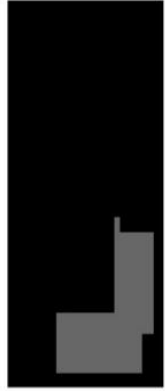

Laje 2

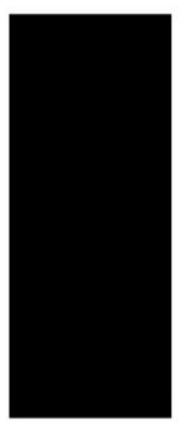

Cobertura

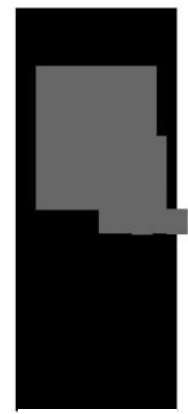

Laje 3

Figura 33 - Diagrama relação lajes e cobertura - vista superior do CPD

O diagrama mostra a relação dos patamares (em cinza) entre si e com a Cobertura (em preto).

[ Subsolo: maior massa no projeto, por estar abaixo do solo não interfere na leveza e transparência.

[ Térreo: conectada a laje 1, inicía o a içagem do edifícil ,e por seu tamanho reduzido cria-se um design afunilado,

[ Laje 1: conectada a Laje 2 e ao Térreo, não é sobreposta a nenhuma delas.

[ Laje 2: conectada a laje 1 e a Laje 3, acima do térreo, porém sua forma segue o mesmo raciocínio porém é diferente.

[ Laje 3: conectada a laje 2 e laje 4, maior em relação a Laje 1 que está logo abaixo,e uma aresta surge na lateral.

[ Laje 4: conectada a laje 3 e 5, continua sequencia de níveis sobepostos e maiores. 
[ Laje 5: conectada a laje 4 e 6, contem a maior área de todos os níveis, ocupando mais da metade do espaço da superior, e fecha o ressalto da laje 3.

[ Laje 6: conectada apenas pela laje 5, finaliza o zigue-zague dos pisos.

[ Laje Superior: encerra o edifício com um simples retângulo, que suaviza e horizontaliza o conjunto de forma pura.

Assim como no RU, o arquiteto usa laminas recortadas dispostas por andares, e vistas em planta nota-se uma disposição sistemática formando mezaninos unidos por rampas e pilares contínuos. Porém diferente do $\mathrm{RU}$, a obra vista por fora não é chapada como podemos observar nos diagramas de tipo de fechamentos. 


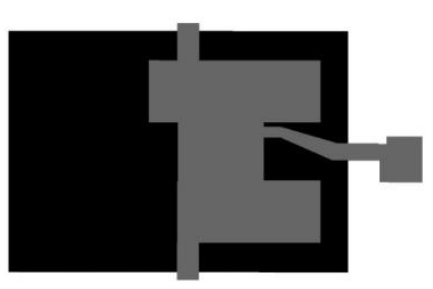

Subsolo

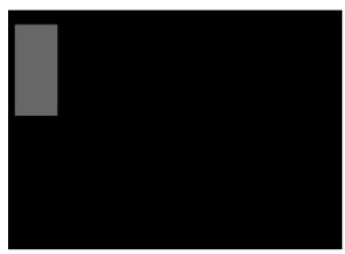

Laje 3
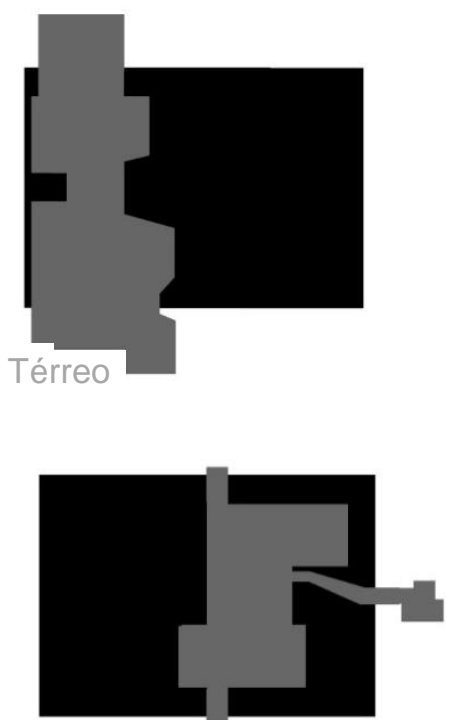

Laje 4

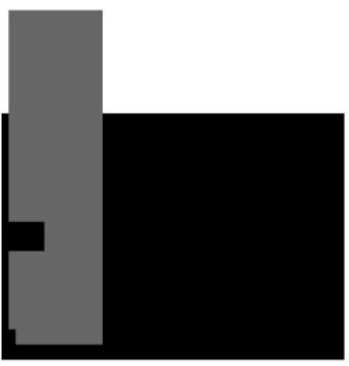

Laje 1

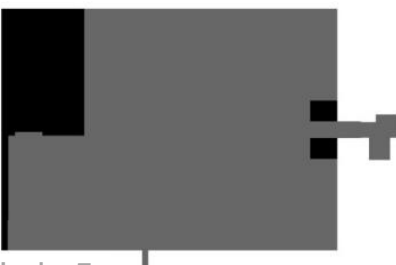

Laje 5

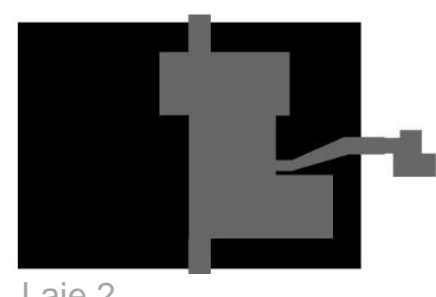

Laje 2

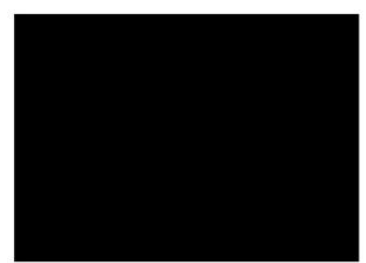

Laje superior

Figura 34 - Diagrama relações lajes e cobertura - vista superior do RU

[ Subsolo: inicia a sequencia de lajes (subsolo, Laje 1, Laje 2) que se conectam com a coluna do elevador através de passarelas curvas, de forma a proporcionar visão ampla e ventilação.

[ Térreo: conecta os dois lados que estão no mesmo patamar fora da edificação.

[ Laje 1: cobertura do térreo e equilíbrio, pois é uma grande geometria ao lado esquerdo.

[ Laje 2: afigura o espelho da laje 4.

[ Laje 3: ocupa um espaço singular, traz leveza pelo seu tamanho reduzido em relação aos demais, devido ao corte da laje 5 seu pé direito é elevado.

[ Laje 4: afigura o espelho da laje 1.

[ Laje 5: piso da cozinha, fechamento de todo ambiente abaixo dele, a criar um esfera separada que é elevado aos outros.

[ Laje Superior: unida a Laje 5 fecha o ambiente todo. 
O trato dos patamares é de aparente desunião, todavia quando analisado, identifica-se harmonia e equilíbrio. O vazio em um nível é ocupado pelo piso do próximo, proporcionando assim mezaninos, ao invés de patamares subsequentes. Formando um complexo jogo de tabuleiros dentro de um paralelepípedo de vidro com um topo de concreto. 


\subsubsection{Relação espelho água}

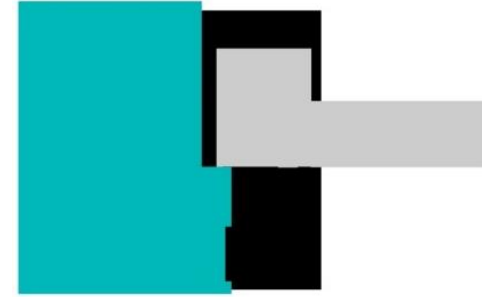

Subsolo

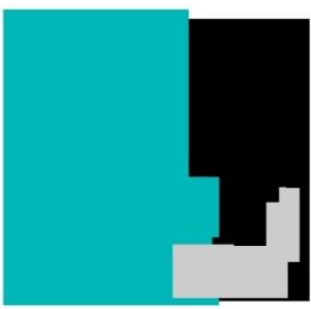

Laje 4

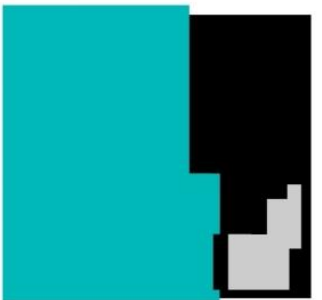

Térreo

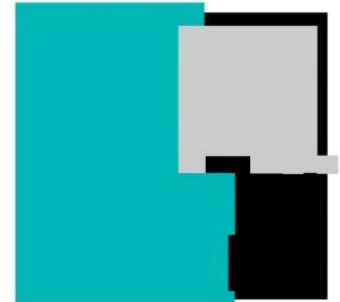

Laje 5

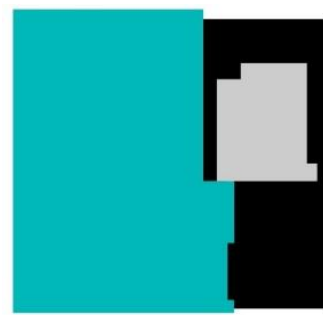

Laje 1

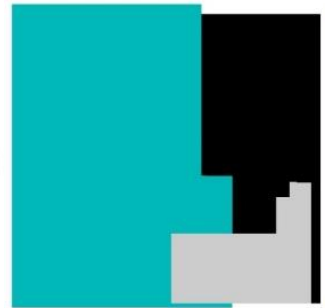

Laje 6

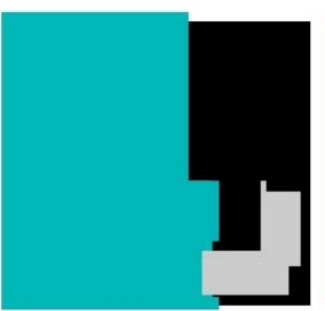

Laje 2

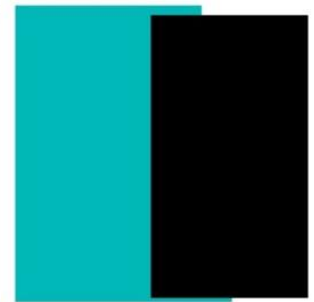

Cobertura

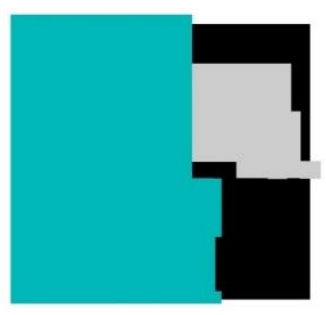

Laje 3

\section{Figura 35 - Diagrama da relação espelho d'água - CPD}

Podemos ver em azul o espelho d'água e em m cinza os patamares e a cobertura em preto.

O arquiteto consegue criar uma coerência muito grande em relação à edificação e ao entorno, ele adere o urbanismo e a edificação não fica presa apenas dentro de paredes, ela conversa com o terreno.

O espelho d'água do CPD é extenso e localiza-se em apenas um lado da edificação (elevação B), o que ao olhar do observador não se destaca, mas completa a visual, auxilia no conforto térmico e horizontaliza ainda mais o edifício, formam caminhos lúdicos, o espelho tem a maior proporção que a cobertura. Pode ser visto por todos os pavimentos, cria relações e muitas vistas diferentes, dinamizando todo o espaço. 

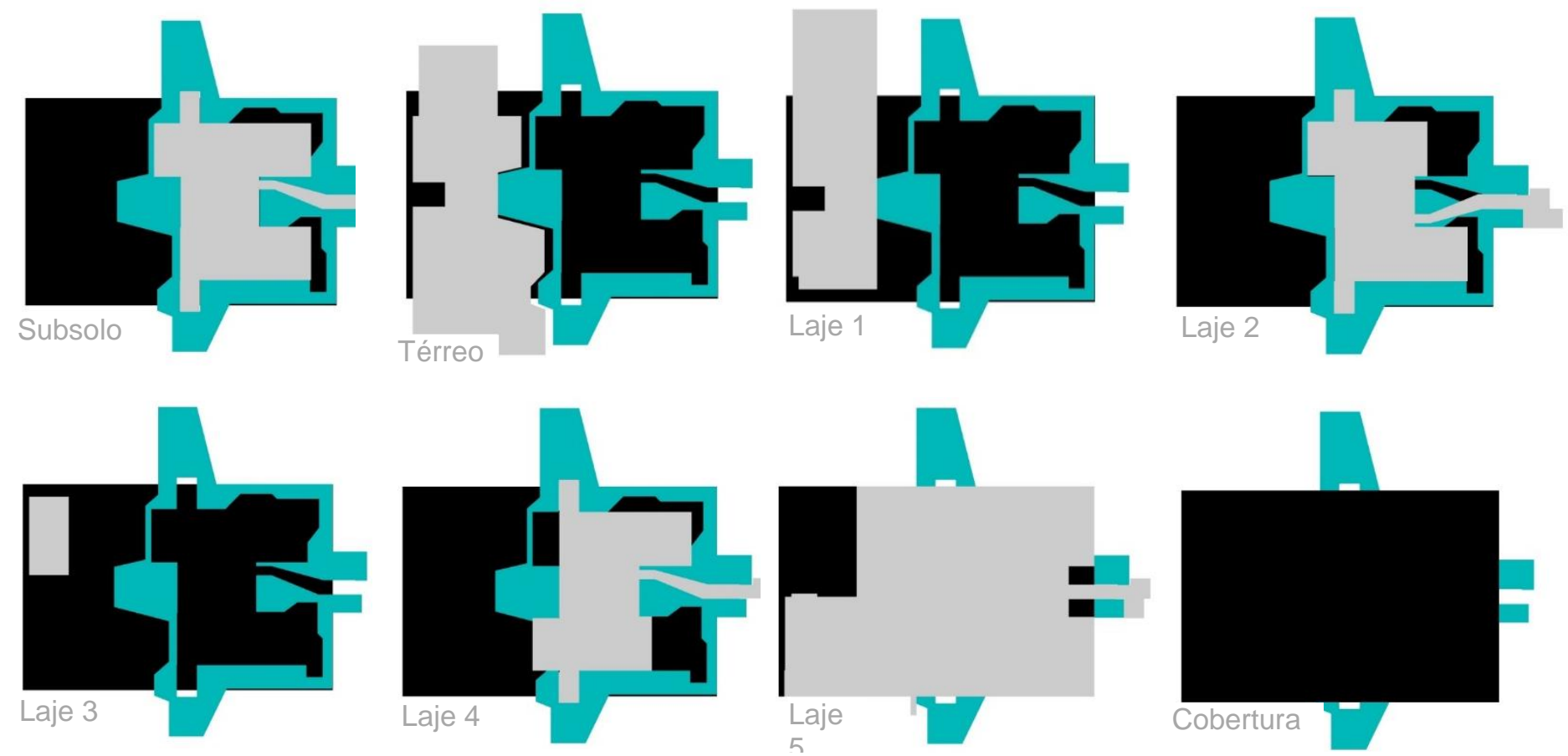

No presente diagrama podemos notar que a água é espalhada envolta do edifício, compondo ângulos retos obtusos, de modo a se misturar ao edifício sem ser um marco focal, apenas compõe a todo conjunto de seções que se cruzam.

Assim como no CPD de todos os pavimentos pode ser visto o espelho d'água, porém não é tão amplo e extenso. 


\subsubsection{Circulação vertical}

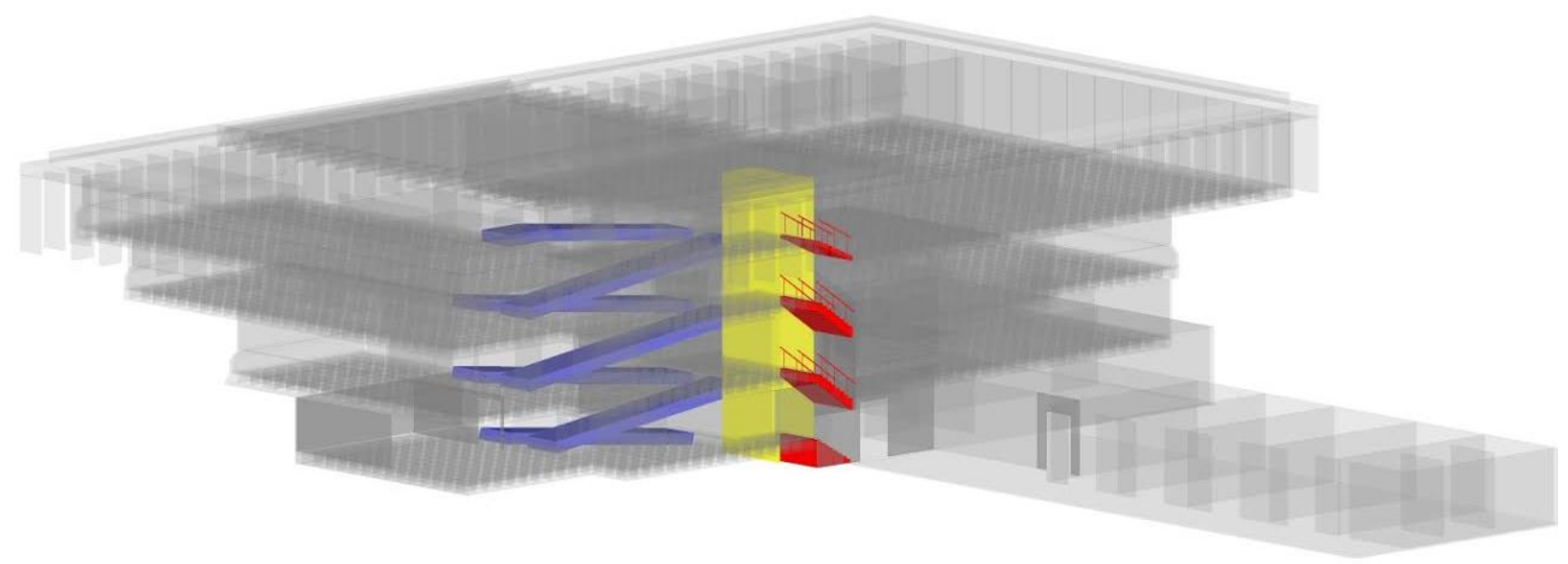

Elevador em amarelo, rampa em azul e escada em vermelho, todos próximos, leva os usuários a se encontrarem sempre no mesmo ponto. Onde está localizada a maior concentração de espaços imersivos, a mais densa massa do prédio concentra-se onde está a circulação vertical. A rampa é o objeto de maior valor, apresenta uma razão estética, tendo uma inclinação leve e facilitando a passagem entre as lajes que são levemente deslocadas de um lado ao outro. 


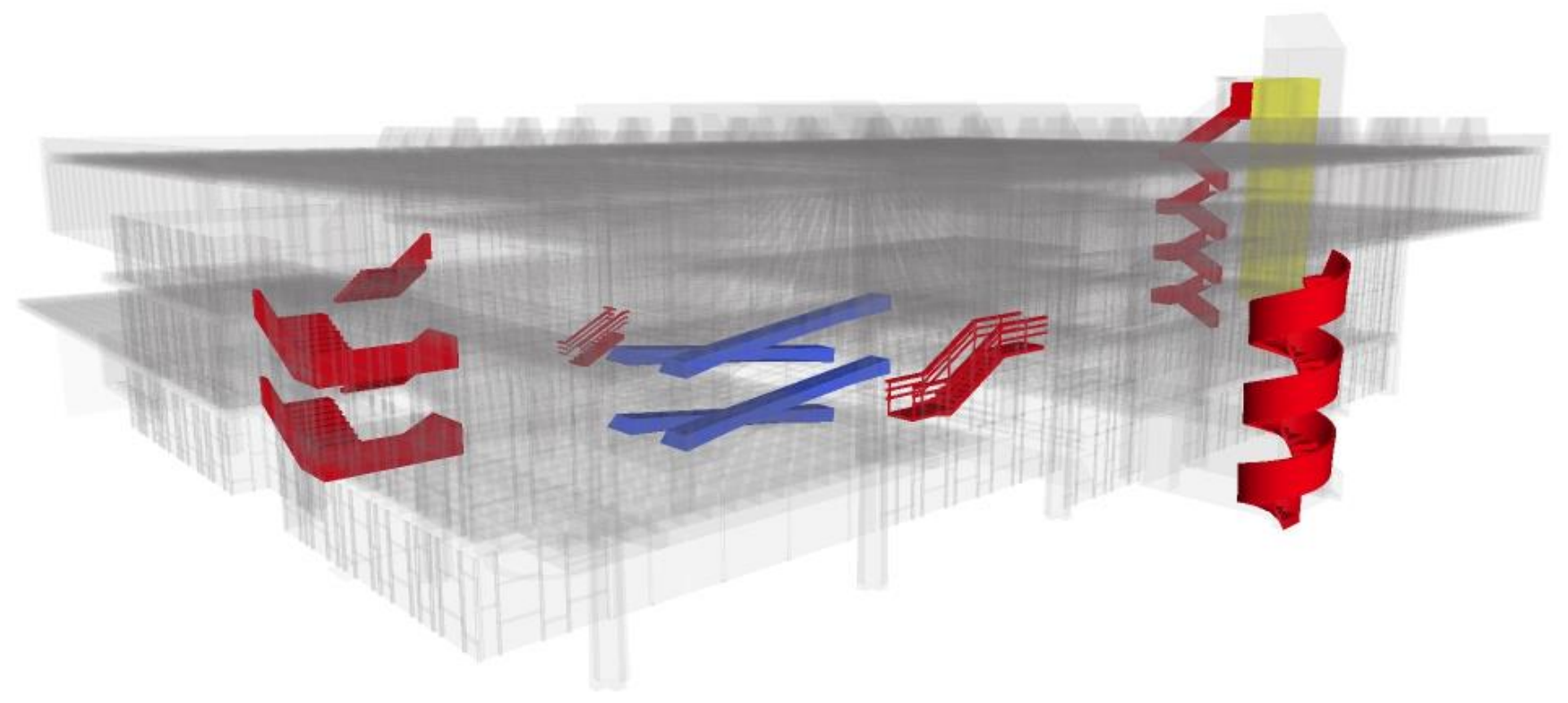

A conexão entre as lajes é feita por rampas escadas e elevadores, todos apresentam a expressividade plástica brutalista. Rampas largas, passarelas com inclinação leve proporcionam vista panorâmica e ampla do interior do restaurante.

As escadas internas unem os patamares e facilitam a circulação e conexão entre os estudantes. A escada externa é pujante, um marco focal, amarra a cozinha ao solo juntando o trabalhador ao usuário, deixa-os no mesmo escalão, manifesta o cunho de causas socialistas do arquiteto.

O elevador é para uso de serviço, facilita a carga e descarga da cozinha no último andar e é de utilização apenas de funcionários.

Rampas são os principais acessos, também os mais utilizados pelo público, os elementos mais evidentes no interior da edificação, largas e de tênue inclinação tornando agradável e fácil o acesso ás lajes, democratizando o espaço. Amplia a visão do observador.

No CPD o arquiteto buscou uma circulação caracterizada por uma maior funcionalidade e simplicidade, apenas a rampa apresenta um grande valor estético. Entretanto, no RU ele busca uma maior valorização plástica, para que os elementos 
da circulação apareçam de maneira a compor esteticamente o edifício. Em ambas as obras as rampas são muito valorizadas, o que difere os dois edifícios é o valor plástico que $o$ arquiteto agregou às escadas, no primeiro caso não é perceptível uma grande preocupação estética, já no segundo é nítida.

\subsubsection{Imersão e Evasão}

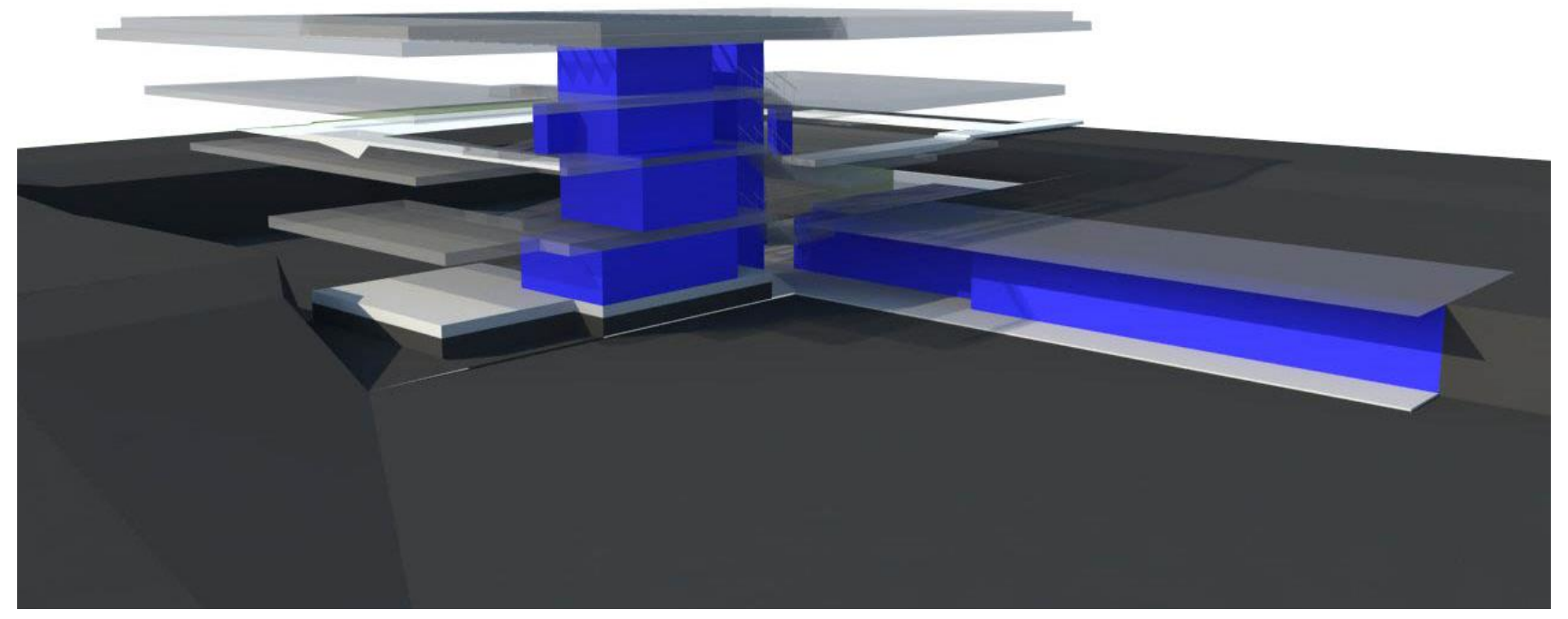

Figura 38 - Diagrama de espaços imersivos - CPD vista 1

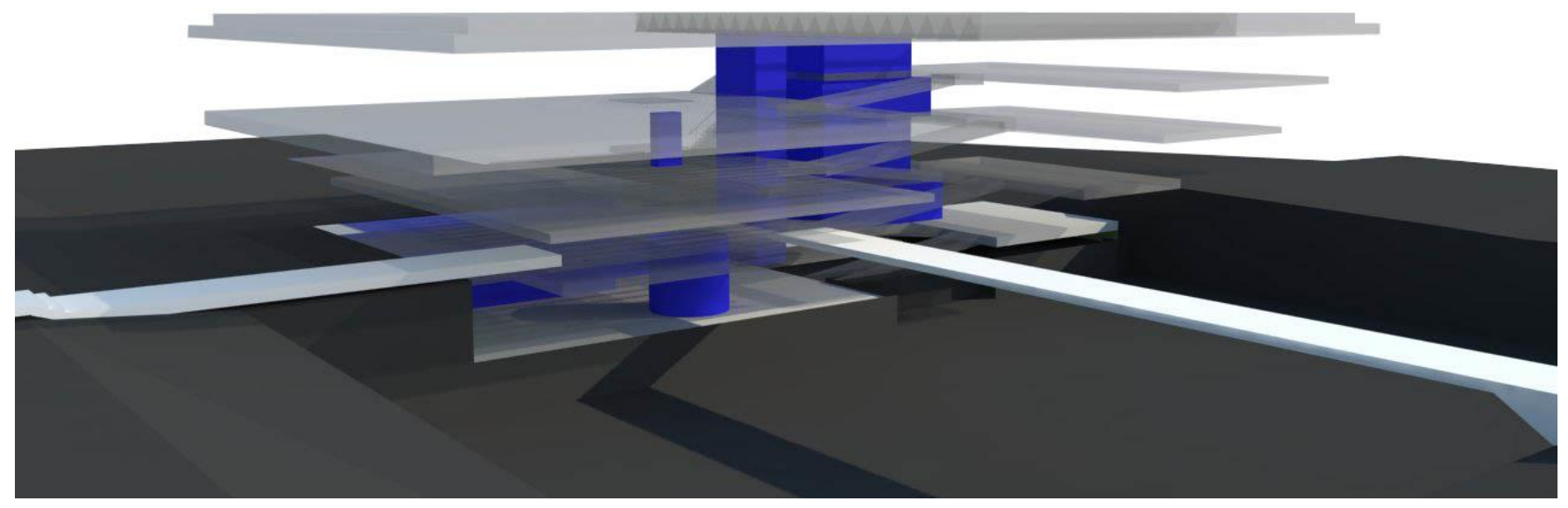

Figura 39 - Diagrama de espaços imersivos - CPD vista 2 
Assim como a circulação vertical, é concentrada, os espaços imersivos verticais ficam reunidos no mesmo pondo das escadas rampas e o elevador, o restante é separado por vidro, tornando o edifício horizontal e fluído. Os espaços imersivos verticais se localizam no subsolo, sendo imperceptível ao observador fora da obra. Os espaços evasivos se estendem a partir da massa imersiva. 


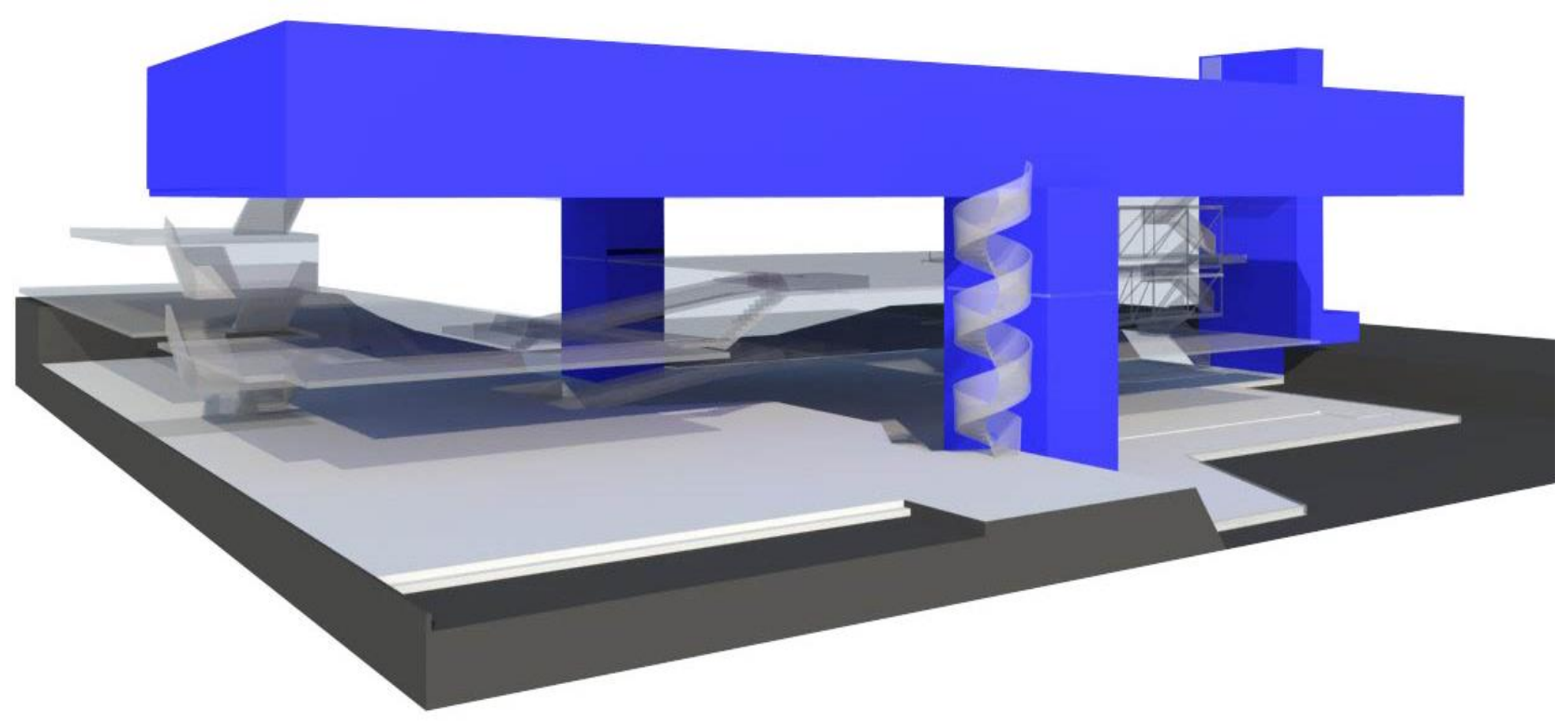

Figura 40 - Diagrama de espaços imersivos - RU vista 1

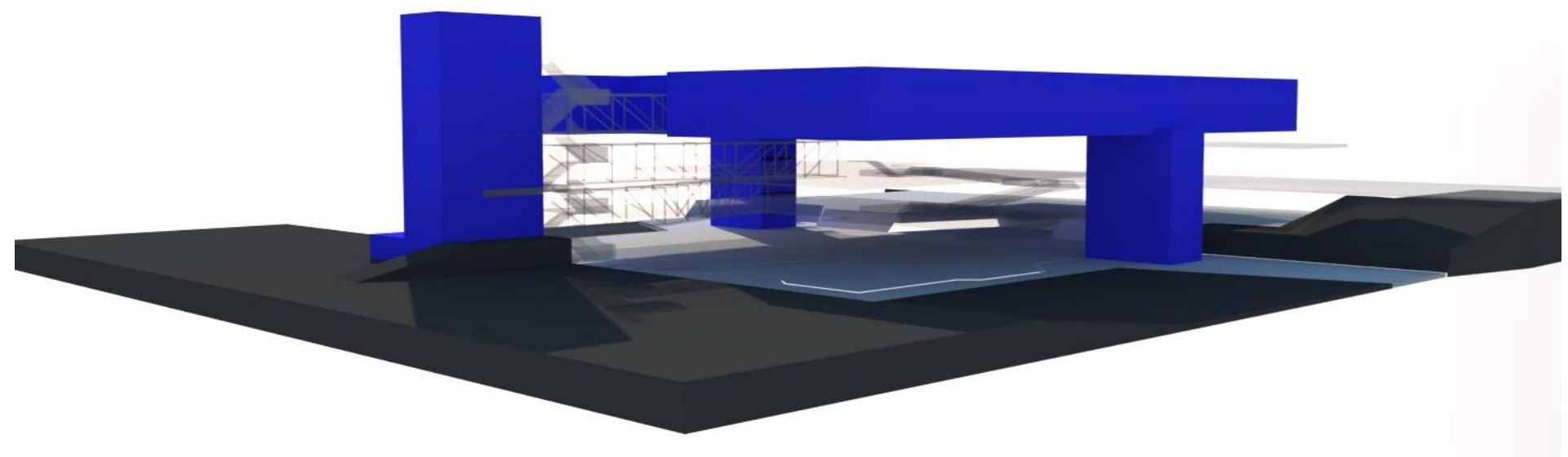

Figura 41 - Diagrama de espaços imersivos - RU vista 2 
A principal massa imersiva é no último andar, aonde se localiza a central de produção e armazenamento de alimentos, é do tamanho do edifício. Os espaços imersivos de menor eminência são apoios aos patamares, uma extensão da massa principal. $O$ volume secundário é anexado ao principal, no elevador, transporte dos alimentos e salas administrativas, vai do subsolo e sobe até formar a parte mais alta de todo edifício. $O$ interior é evasivo, pois é formada apenas por patamares desencontrados unidos por rampas, isolado do exterior com pele de vidro. Libera o núcleo para a uma visão panorâmica, maior interação e noção de liberdade dos estudantes.

O RU e o CPD se assemelham por ter espaços imersivos ocupando menor área que os evasivos, os concentrados imersivos são dedicados à ambiente cuja aplicabilidade não permite evasão e os evasivos a maior permanência dos estudantes, proporcionam espaços expansivos. Ao contrário do CPD no RU tudo que está abaixo da grande área imersiva é um núcleo evasivo, no CPD a evasão é a partir do imersivo vertical. 
2.1.6. Estrutura
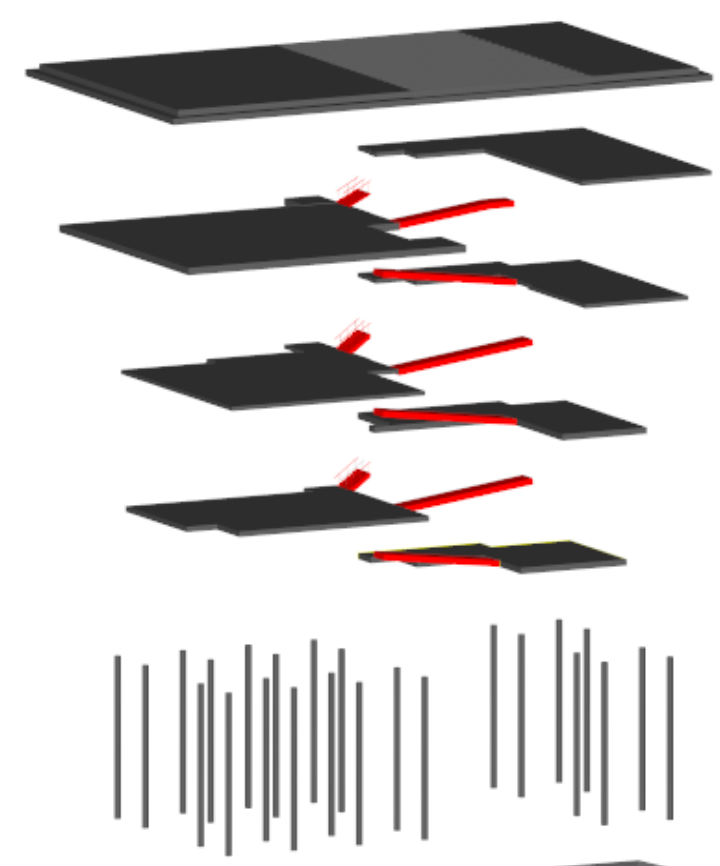

Figura 42 - Diagrama de estrutura - CPD 


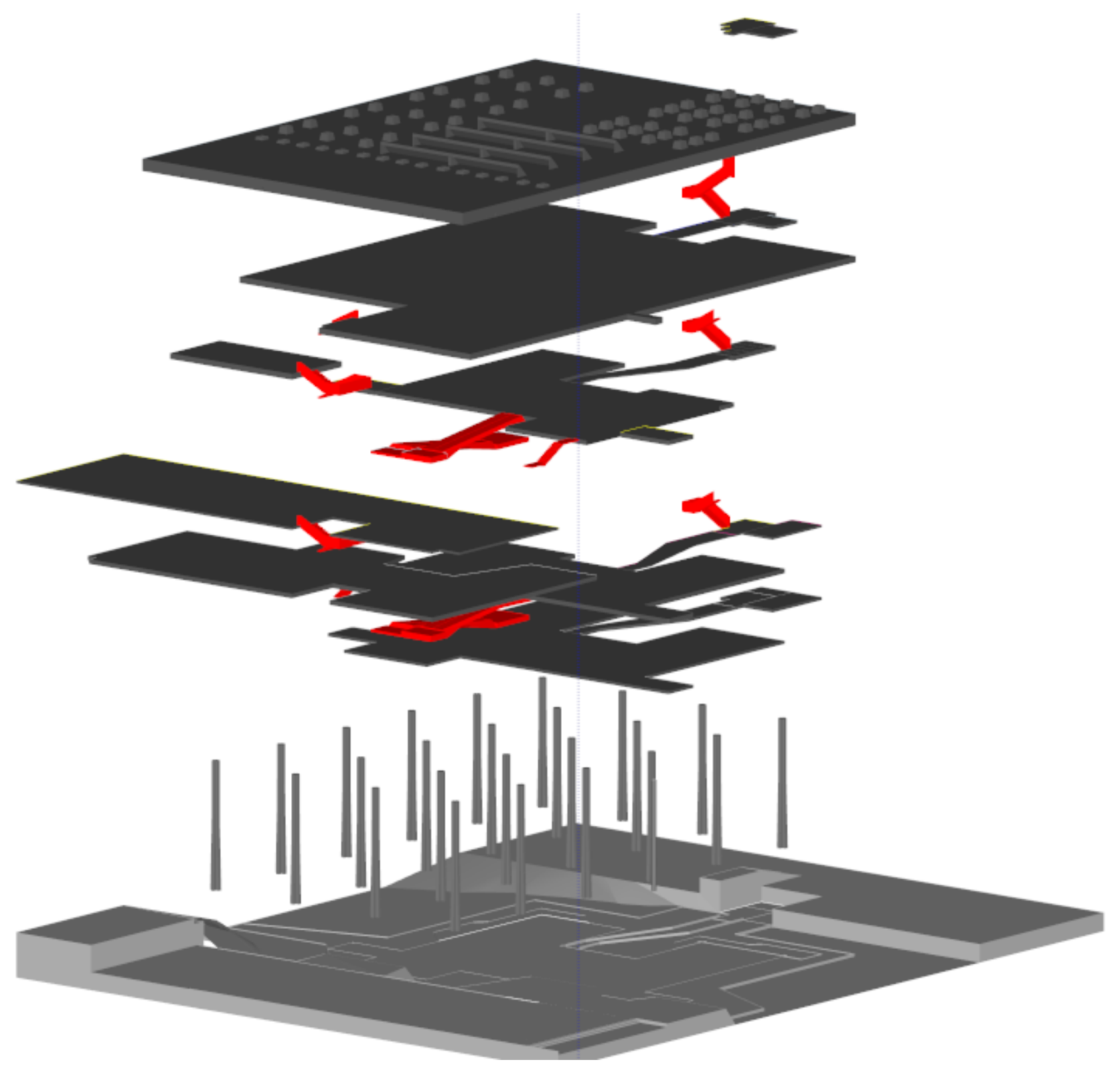

Figura 43 - Diagrama de estrutura - RU

O arquiteto não esconde os pilares nas paredes ou as vigas e lajes com forros, ele utiliza o pilar como elemento plástico, característica muito evidente da vertente brutalista. Os pilares nascem no subsolo, penetram laje à laje, e morrem na cobertura. As lajes ostentam as nervuras, em concreto aparente. 


\subsubsection{Abertura zenital}

A luz natural penetra através das aberturas na cobertura e espalha luminosidade para a circulação vertical e distribui a claridade aos demais pavimentos.

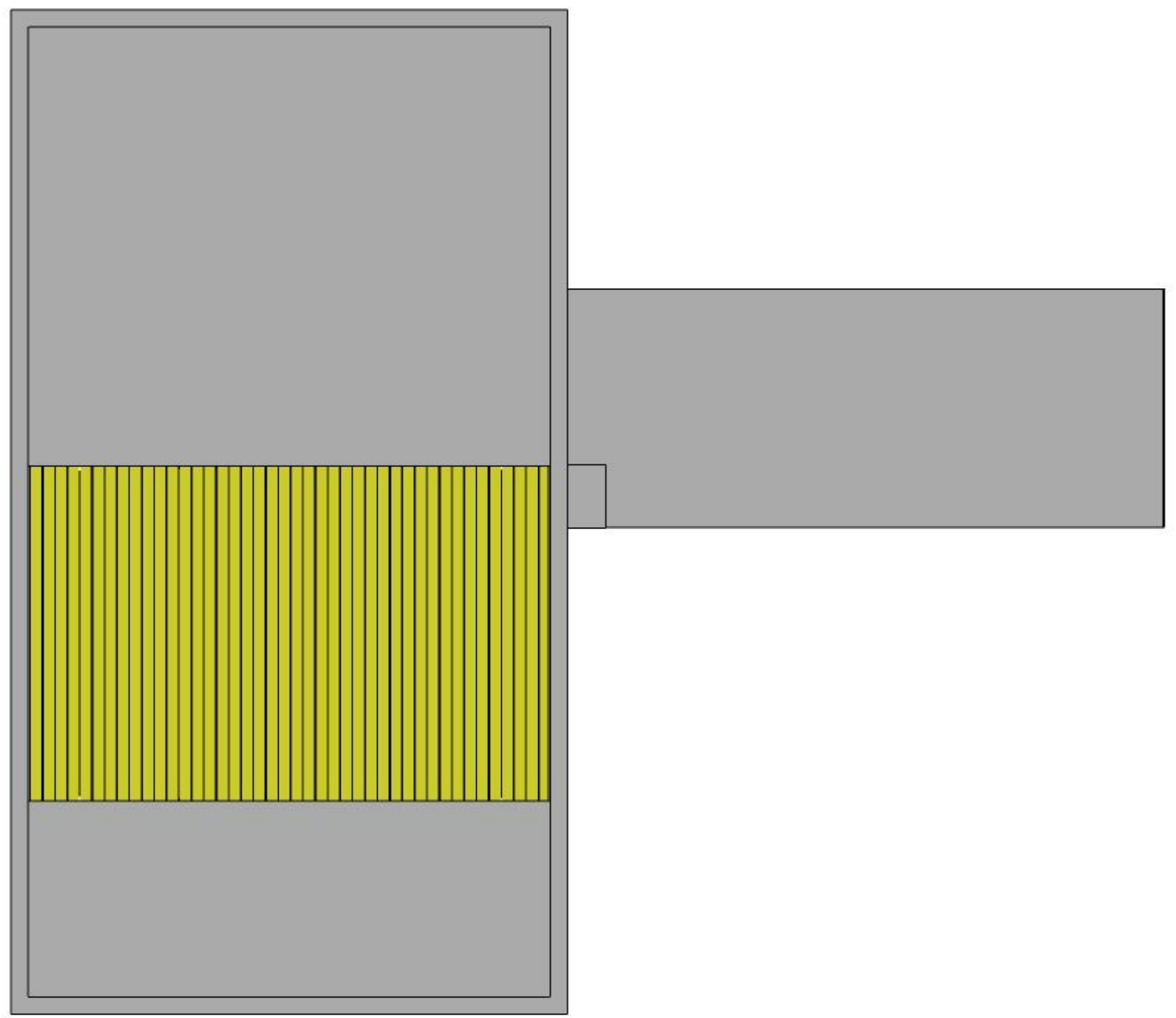

Figura 44 - Diagrama de abertura zenital - Vista superior CPD 


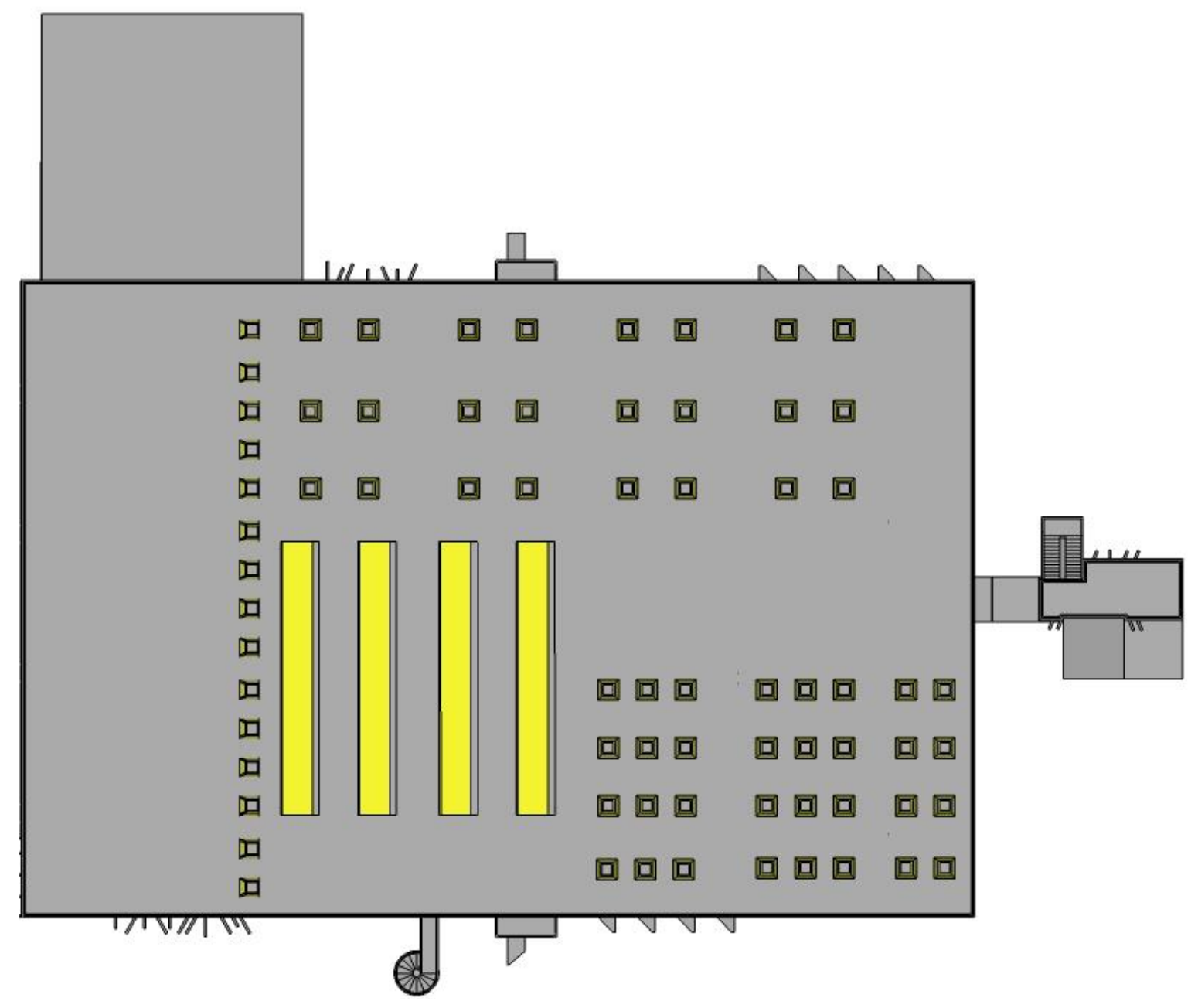

Figura 45 - Diagrama de aberturas zenitais - Vista superior $R U$

A cobertura em toda a sua extensão, possui inúmeras claraboias que proporcionam entrada de luz natural e ventilação ao ambiente interno (cozinha), valoriza o espaço e proporciona conforto luminoso e ambiental aos usuários. 


\subsubsection{Tipos de fechamentos}

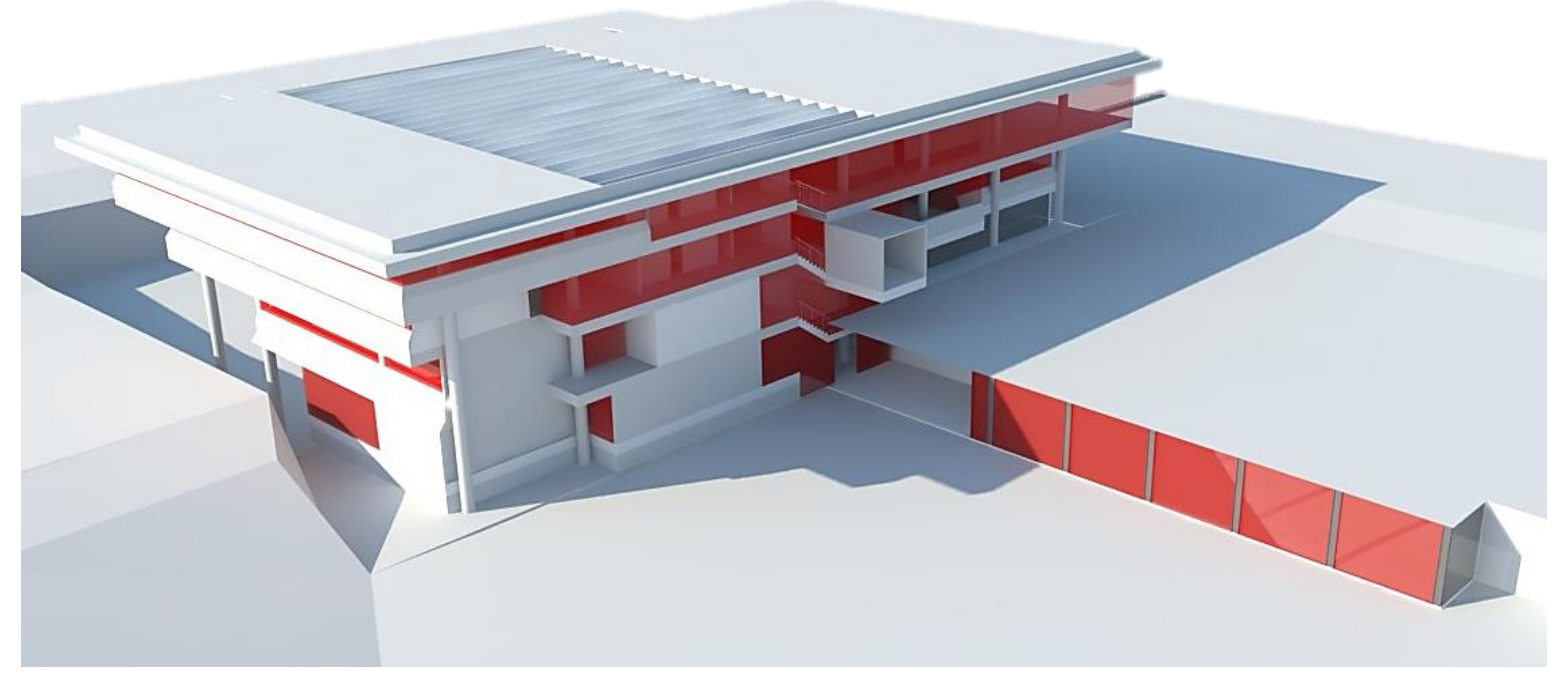

Figura 46 - Diagrama de fechamento em vidro - CPD vista 1

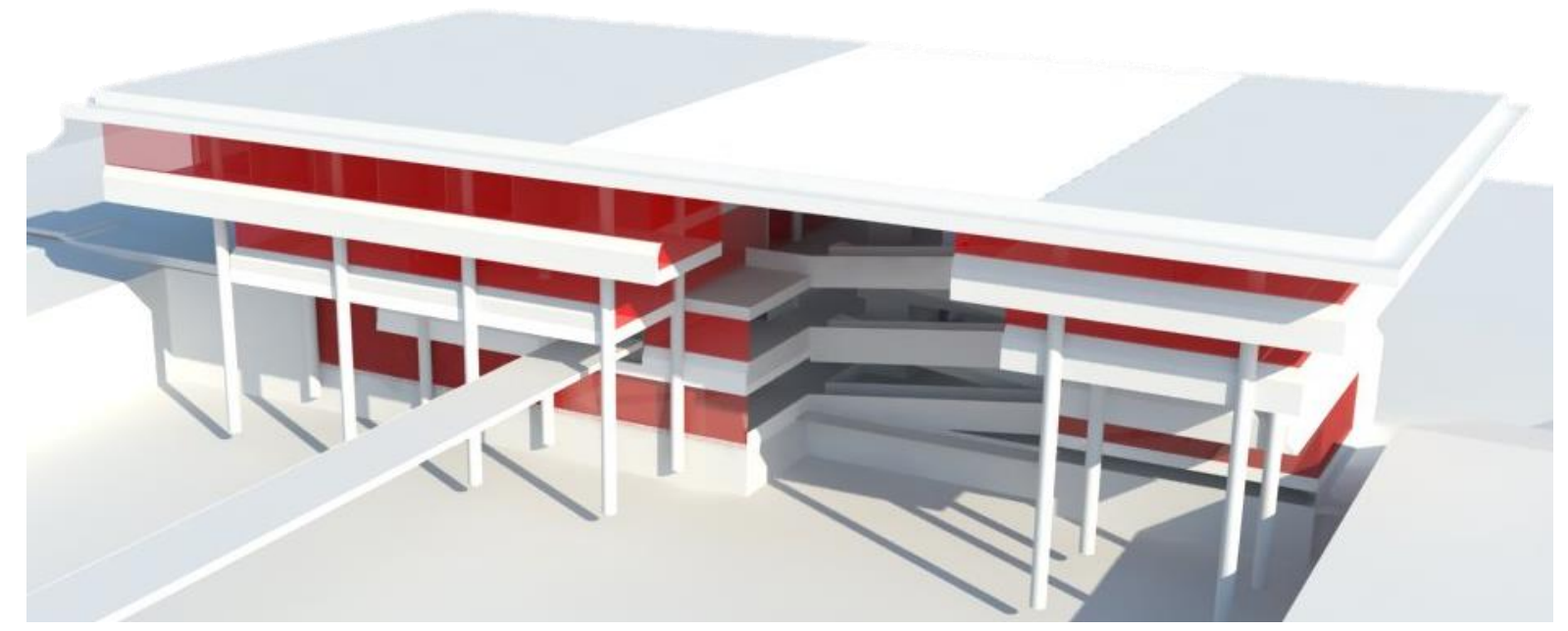

Figura 47 - Diagrama de fechamento em vidro - CPD vista 2

Revestindo as fachadas da obra e conectando visualmente as áreas internas, 0 arquiteto faz uso abusivo de peles de vidro, o que suaviza a forte massa do concreto aparente deixando a geometria leve. 


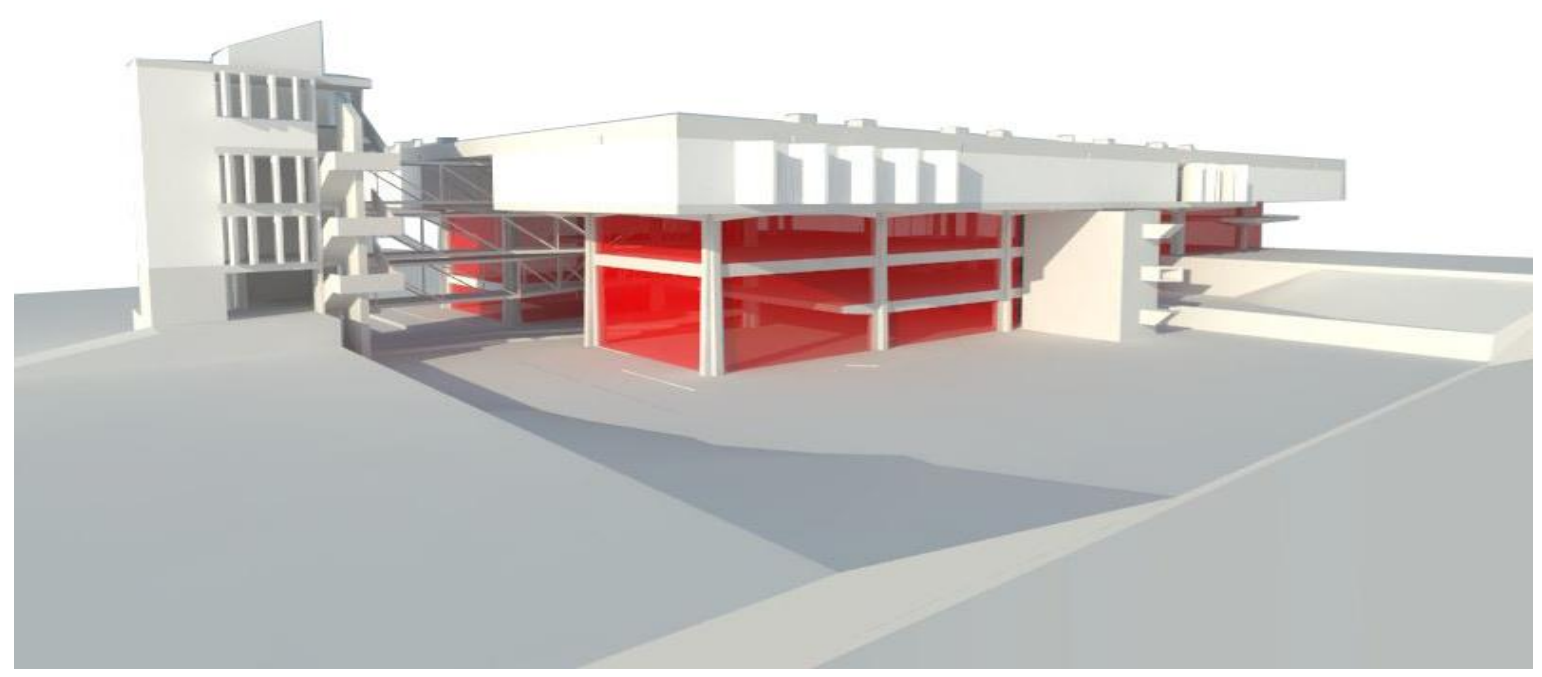

Figura 48 - Diagrama de fechamento em vidro - RU vista 1

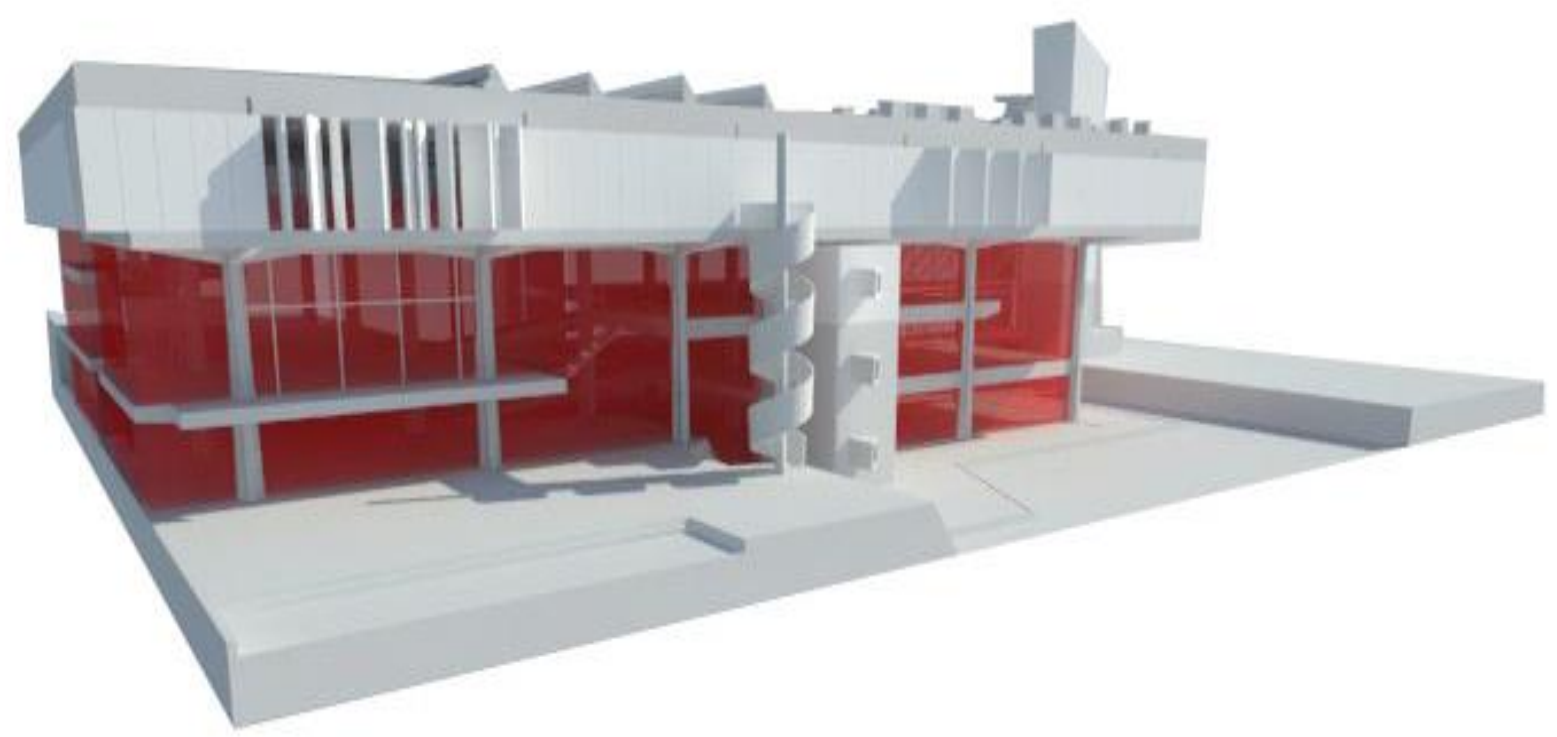

Figura 49 - Diagrama de fechamento em vidro - RU vista 2

A pele de vidro desce da massa em concreto e veste todos os patamares, onde estão situadas as mesas para alimentação, unindo visualmente o externo e interno do edifício. A forma com que as placas de vidro são colocadas permite a circulação de ar e simula um movimento de água caindo. Em ambos, o vidro entra com coadjuvante do concreto aparente e suaviza a massa, porém, aplicado de formas diferentes, no caso do RU o vidro veste a fachada de maneira com que os pavimentos não são tão perceptíveis avistado externamente. No projeto do CPD o vidro entra cobrindo os pavimentos como esquadrias em sua maioria, iniciado na altura do guarda-corpo e finalizado no início da laje superior, dessa maneira quando fora do edifício percebese aonde tem início e fim cada pavimento. 


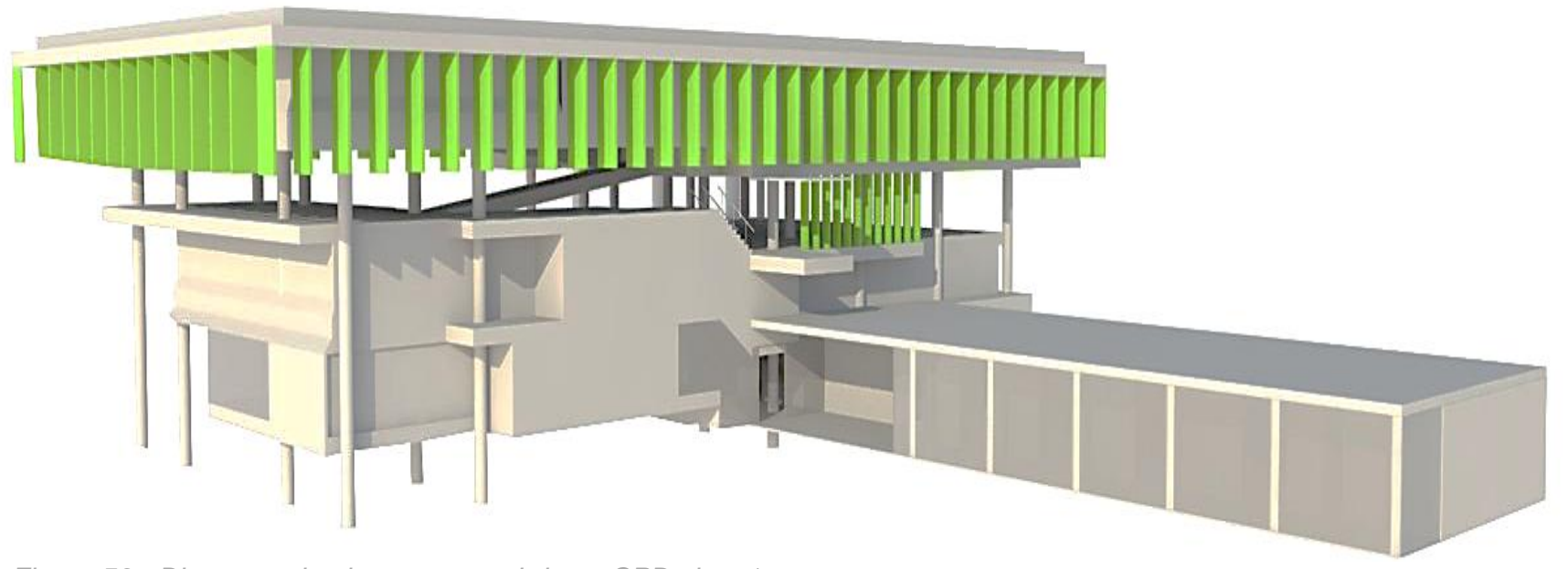

Figura 50 - Diagrama de elementos em brise - CPD vista 1

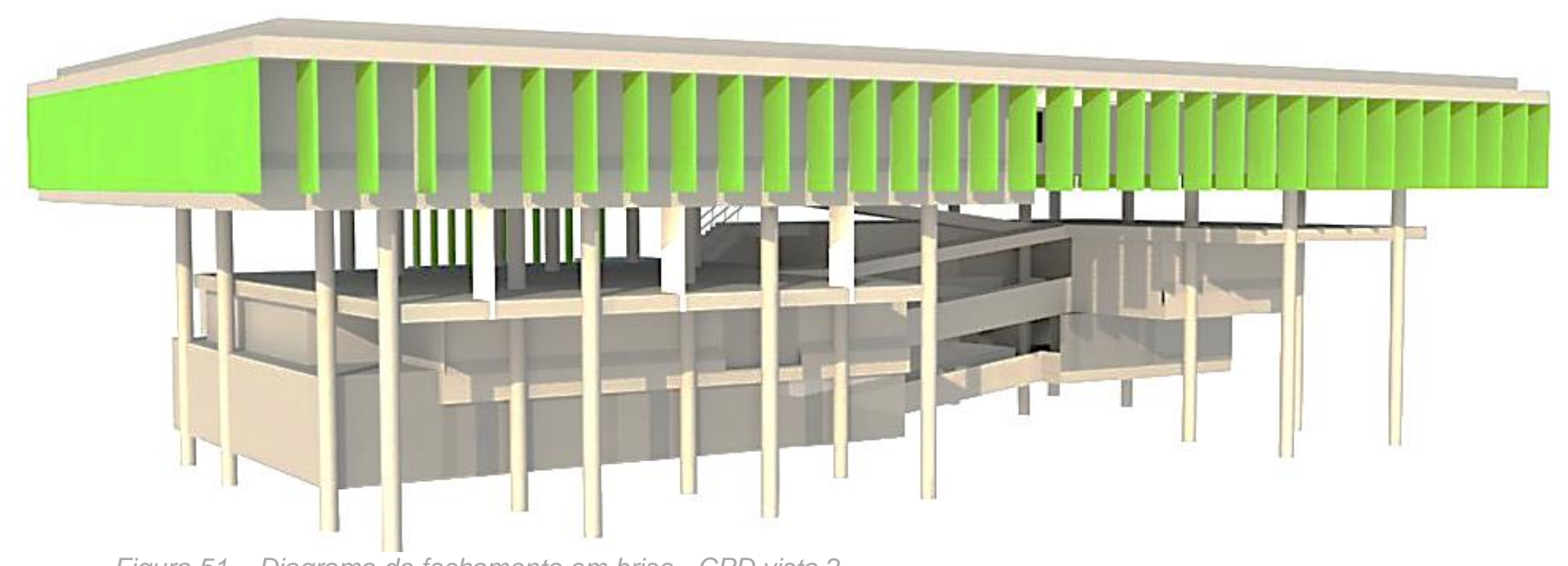

Figura 51 - Diagrama de fechamento em brise - CPD vista 2

Os brises laterais revestem totalmente o ultimo pavimento, substituem as paredes, regula a entrada de sol e vento vindos do exterior. Pavimentos inferiores não são marcados por brises, a incidência solar é menor pois ficam recuados dos superiores. $\mathrm{Na}$ laje superior os elementos são fixos e formam aberturas zenitais, ficam sobre a circulação horizontal, iluminando e ventilando a área.

Elementos em concreto aparente e são fixos, integra a luz natural aos poucos ambiente fechados em quatro paredes. 


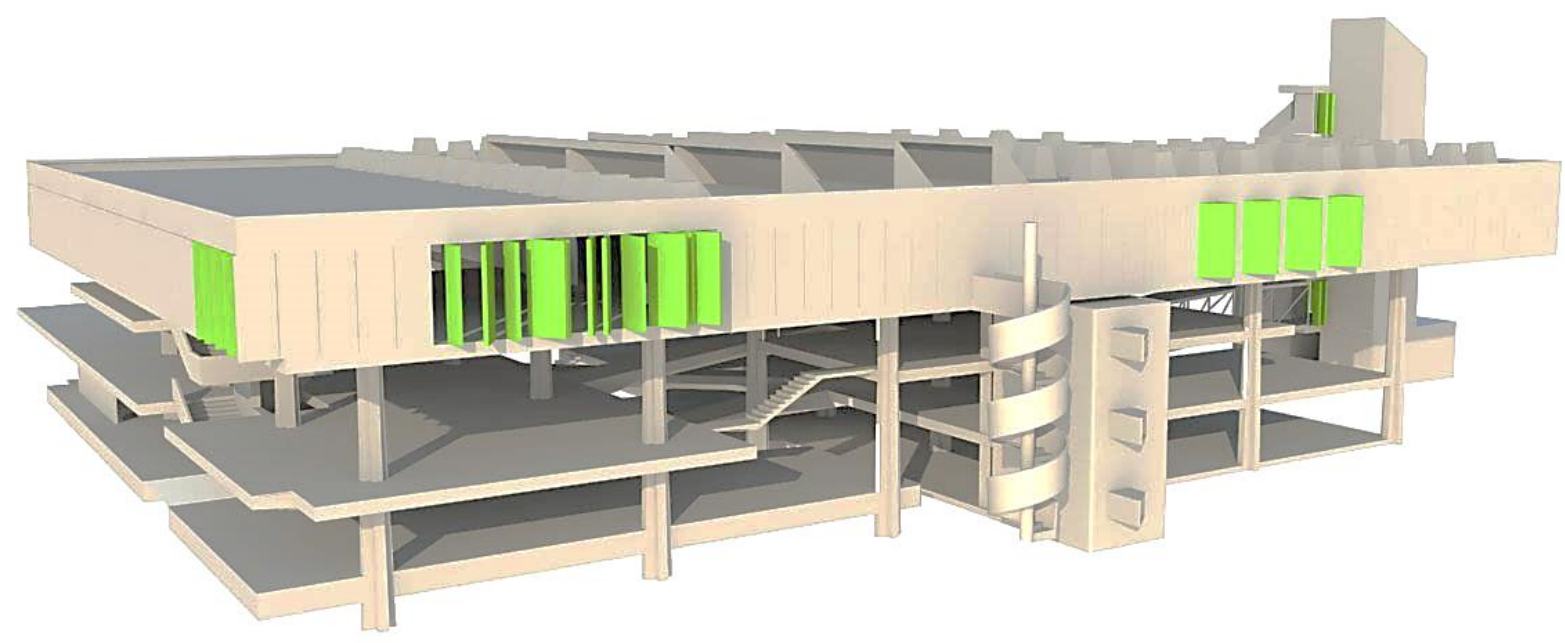

Figura 52 - Diagrama de fechamento em brise - RU

Existe uma valorização do brise como elemento plástico em ambos os projetos, próprio para o clima de Brasília. Porém no Restaurante o componente é fixo e usado pouco, diferentemente do CPD. 


\subsubsection{Topografia}

\section{vista 1}
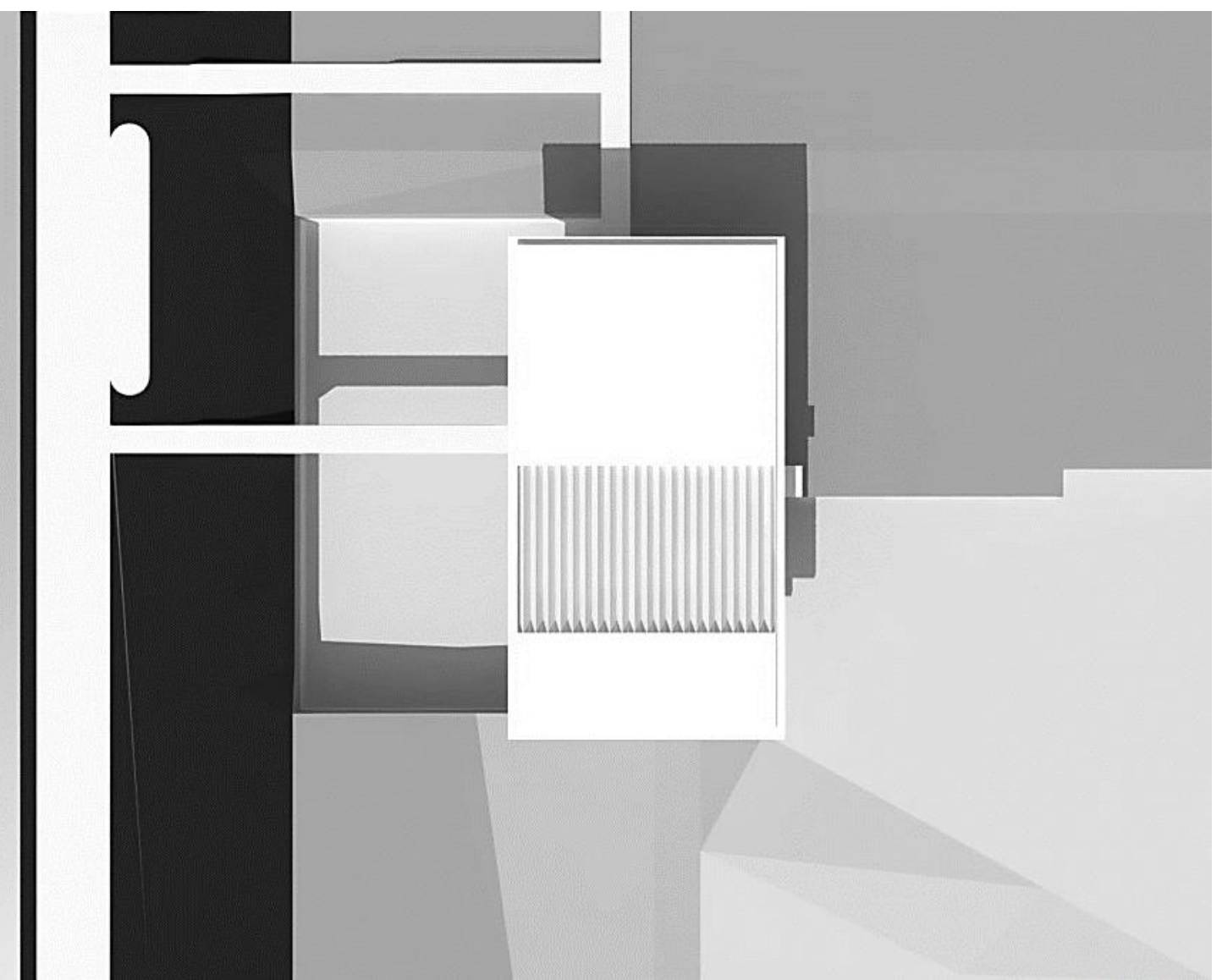

vista 2

Figura 53 - Diagrama de topografia CPD - vista superior

Em cinza escuro é evidenciado os pontos topográficos mais altos e em cinza claro os mais baixos.

O CPD manifesta uma topografia variada, cada elevação se revela em um nível diferente, o solo envolto ao espelho d'água e a calçada no projeto o nível é elevado, o nível vai caindo conforme vai ao sentido oposto, de forma que um lado do subsolo fica sob o solo e o outro lado tem vista para fora.

$\mathrm{O}$ arquiteto trata o terreno do $\mathrm{RU}$ como uma continuação do edifício, formando um jogo de patamares tanto no interior quanto no urbanismo, o horizonte muda conforme o observador caminha ao redor do restaurante. Alguns pontos internos ficam no mesmo nível dos externos, outros não. Dessa maneira o arquiteto brinca com a setorização das entradas. 
Nos dois projetos a preocupação com o tratamento dos desníveis é fortemente evidenciada, a topografia tem valor equivalente à arquitetura.

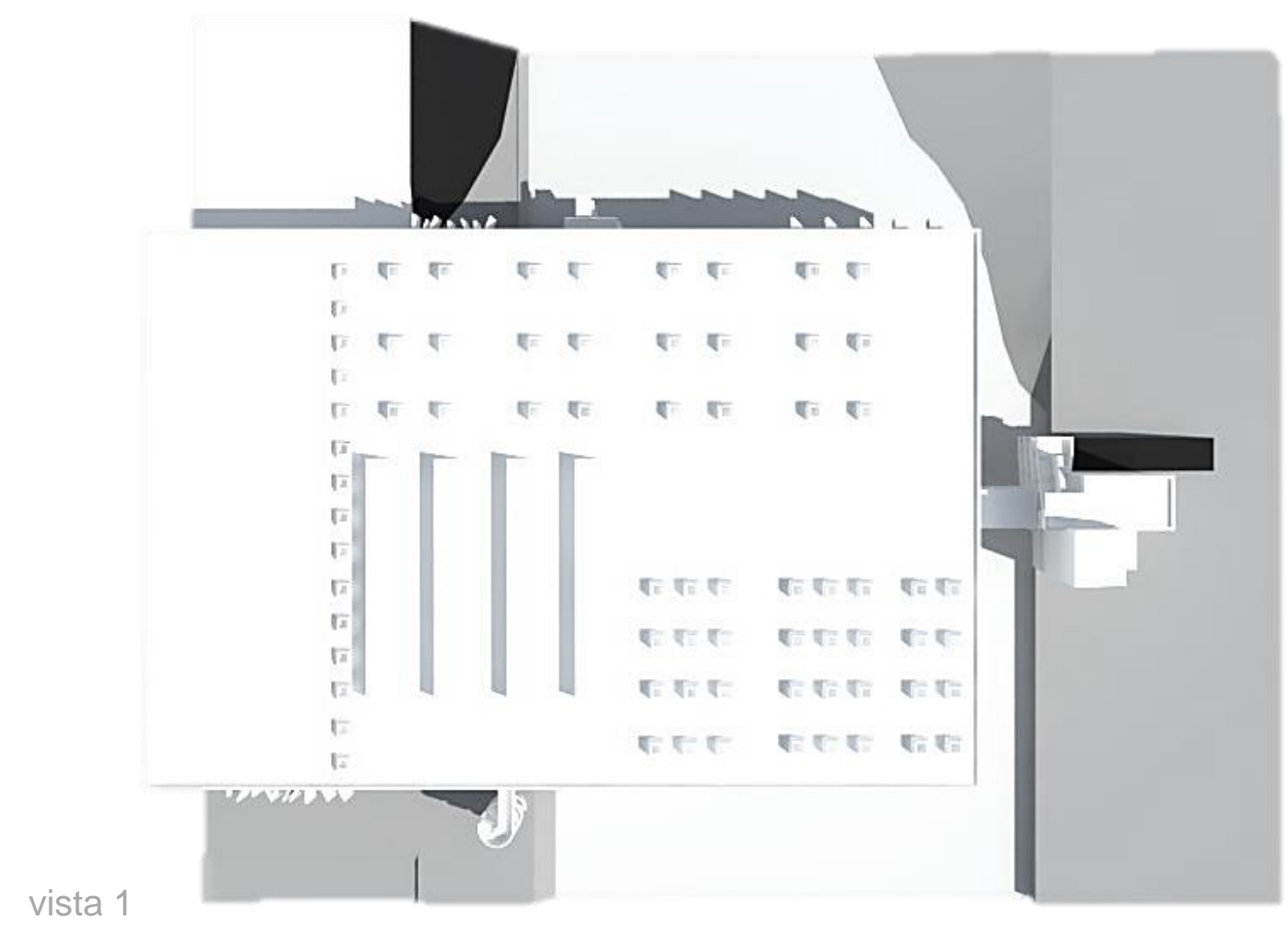

vista 2

Figura 54 - Diagrama de topografia - RU - vista superior

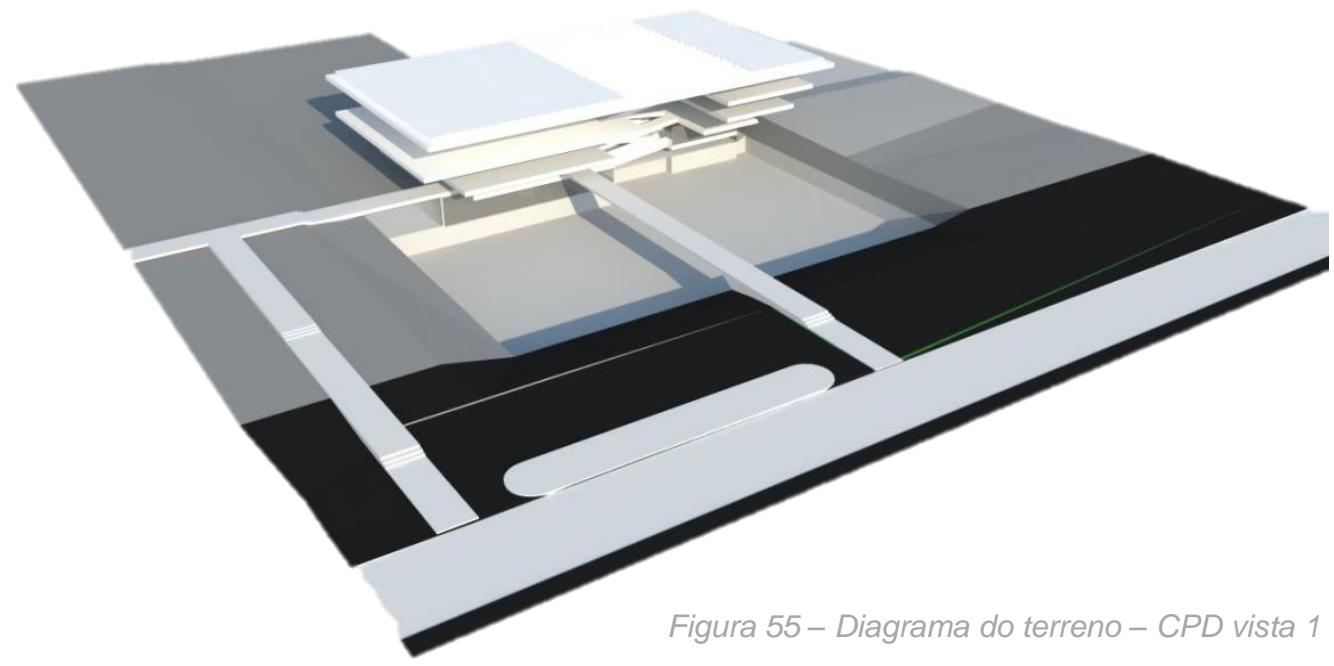



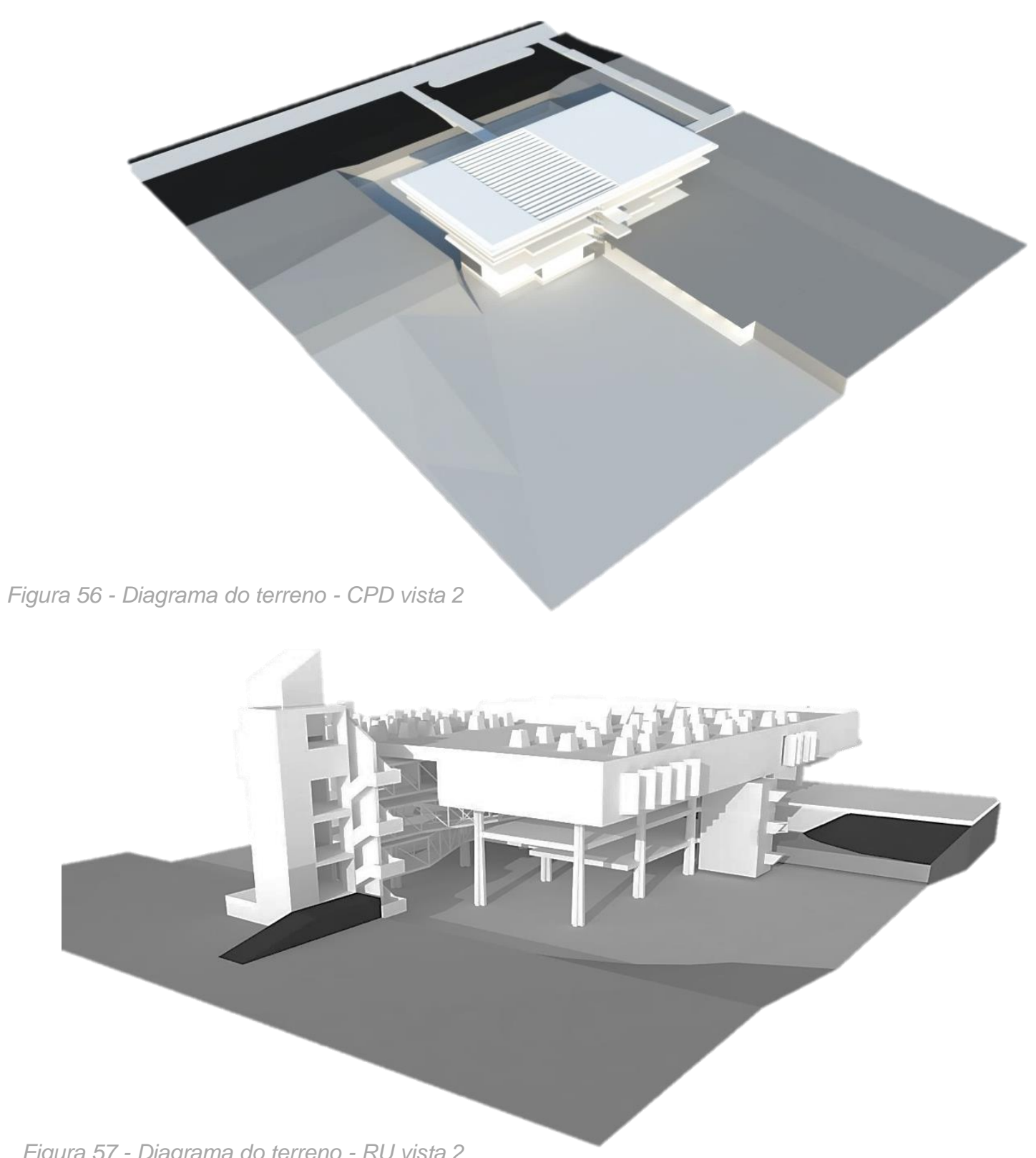

Figura 57 - Diagrama do terreno - RU vista 2

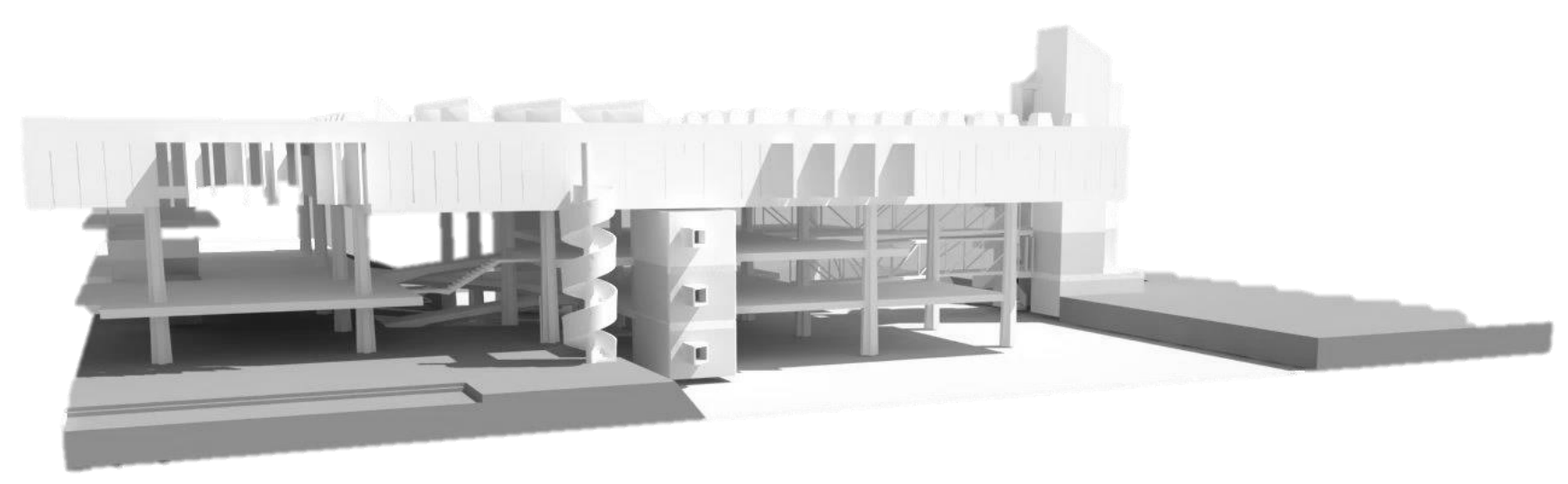

Figura 58 - Diagrama do terreno - RU vista 1 


\section{Conclusão}

O arquiteto e professor Galbinski teve uma relevante contribuição para o desenvolvimento da vertente brutalista brasiliense, vindo inclusive, posteriormente, a influenciar o desenvolvimento da arquitetura em Porto Alegre.

José Galbinski foi indiscutivelmente discípulo de Artigas, entretanto, em seus projetos como o RU e o CPD pode-se evidenciar uma arquitetura mais limpa, percebe-se uma leveza maior e um maior cuidado com o acabamento, características próprias dos cariocas. O que traz a característica leve é uma inversão de peso causada pela maneira como ele trata a transparência, colocando as partes mais densas dos edifícios nos últimos pavimentos e explorando os visuais nos andares mais baixos, seus edifícios participam do urbanismo de maneira presente, a relação com a água e a forma que se abrem ao meio externo convida a entrada do expectador, além do tratamento dos patamares internos que se cruzam com a topografia externa. Artigas tem pouca ou nenhuma preocupação com o acabamento do concreto aparente, quer evidenciar aquela história, também tem uma arquitetura densa, carregada, o edifício geralmente tem grandes panos e/ou empenas que isolam-no do meio externo, produzindo uma relação somente interna, um trabalho com relação fenomenológica.

No Restaurante-UnB, o arquiteto mostra bastante seus valores políticos na arquitetura, assim como Artigas. No projeto buscou-se valorizar a classe trabalhadora, invertendo a posição da cozinha, que historicamente, desde a época colonial era localizada no subsolo. Foi escolhido o local de "maior valor" do prédio para que houvesse uma valorização do trabalhador e também uma maior circulação de ar. ${ }^{17}$

\footnotetext{
${ }^{17}$ Conforme depoimento do arquiteto à Emilia Stenzel.
} 


\section{Referências bibliográficas}

ARTIGAS, Vilanova. Caminhos da Arquitetura: Vilanova Artigas. São Paulo, Cosac \& Naify, 1999.

BASTOS, Maria Alice Junqueira. Pós-Brasília: Rumos da Arquitetura Brasileira. São Paulo: Ed. Perspectiva/FAPESP, 2003.

BRUAN, Yves. Arquitetura contemporânea no Brasil. São Paulo, Editora Perspectiva,2002.

FRAMPTON, Kenneth. História critica da arquitetura moderna. São Paulo, Martins Fontes, 2000.

LUCCAS, Luis Henrique Haas, Concreto aparente e valorização da estrutura: A influência estética do brutalismo em Porto Alegrenos anos 60/70, X Seminário Docomomo Brasil, PUC-PR, Curitiba, 2013.

STENZEL, Emilia, 50 Anos de Arquitetura. Editora Senac/Anual, Brasília, 2010.

Material do Núcleo de Documentação e Pesquisa da Arquitetura e do Urbanismo de Brasília - CAU/UniCEUB. 